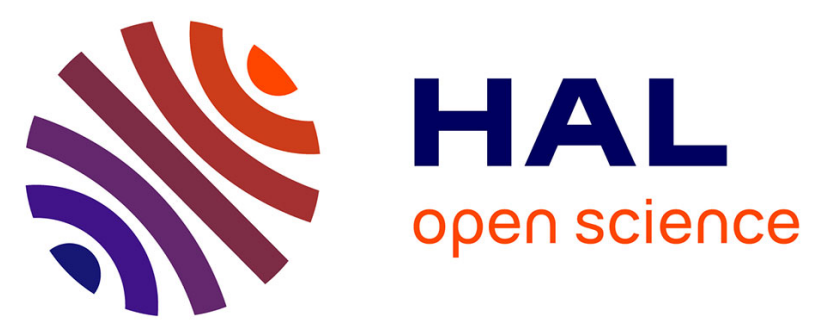

\title{
Slab-derived metasomatism in the Carpathian-Pannonian mantle revealed by investigations of mantle xenoliths from the Bakony-Balaton Highland Volcanic Field
}

\author{
Laura Créon, Guillaume Delpech, Virgile Rouchon, François Guyot
}

\section{To cite this version:}

Laura Créon, Guillaume Delpech, Virgile Rouchon, François Guyot. Slab-derived metasomatism in the Carpathian-Pannonian mantle revealed by investigations of mantle xenoliths from the BakonyBalaton Highland Volcanic Field. Lithos, 2017, 286-287, pp.534 - 552. 10.1016/j.lithos.2017.06.004 . hal-01637216

\section{HAL Id: hal-01637216 \\ https://hal-ifp.archives-ouvertes.fr/hal-01637216}

Submitted on 17 Nov 2017

HAL is a multi-disciplinary open access archive for the deposit and dissemination of scientific research documents, whether they are published or not. The documents may come from teaching and research institutions in France or abroad, or from public or private research centers.
L'archive ouverte pluridisciplinaire HAL, est destinée au dépôt et à la diffusion de documents scientifiques de niveau recherche, publiés ou non, émanant des établissements d'enseignement et de recherche français ou étrangers, des laboratoires publics ou privés. 


\section{Slab-derived adakitic metasomatism in the Carpathian-Pannonian mantle}

2 revealed by mantle xenolith investigations from the Bakony-Balaton

3 Highland Volcanic Field

4

Laura Créon $^{a}$, Guillaume Delpech ${ }^{b}$, Virgile Rouchon $^{a}$ and François Guyot ${ }^{c}$

6

7

8

9

10

11

12

13

14

15

16

17

${ }^{a}$ IFP Energies nouvelles, 1 \& 4 avenue Bois Préau, 92852 Rueil-Malmaison Cedex, France ; ${ }^{B}$ Geosciences Paris Sud department, Paris Sud University, Bâtiment 504, 91405 Orsay Cedex, France ; ${ }^{C}$ IMPMC, Museum National d'histoire Naturelle, Sorbonne Universités, CNRS, UPMC, IRD, 61 Rue Buffon, 75005 Paris, France ;

Corresponding Author: Laura Créon, lauracreon@gmail.com; Present address: Universidad Nacional Autónoma de México, Centro de Geociencias, Campus Juriquilla, A.P. 1-742, Boulevard Juriquila No. 3001, Juriquilla. Qro., C.P. 76230

Abstract

We report new major and trace element data on minerals and glass from fifteen xenoliths from four different locations (Szentbékkálla, Szigliget, Füzes-tó and Mindszentkálla) in the Bakony-Balaton Highland Volcanic Field (Pannonian Basin, Central Europe). We show evidences for different stages of partial melting and metasomatism in the lithospheric mantle. The relict mantle minerals show compositions related to previous lithospheric mantle conditions, resulting from (1) an important early stage partial melting ( 10-15\%) event indicated by a low modal content of clinopyroxene (cpx) 4-9 vol. \% and low HREE contents in $\operatorname{cpx}\left((\mathrm{La} / \mathrm{Yb})_{\mathrm{N}}=0.2\right.$ to 0.8$)$, and (2) a metasomatic event associated to the crystallization of pargasite amphiboles and enrichment of cpx trace element patterns $\left((\mathrm{La} / \mathrm{Yb})_{\mathrm{N}}=0.7\right.$ to 15.7$)$. A more recent metasomatic event is widespread and associated to the breakdown of 
amphibole and to the formation of silicate melt pockets, forming a network of melt veins and pockets associated with large $\mathrm{CO}_{2}$ vesicles at grain boundaries. The melt in veins is trachyandesitic and displays trace element patterns very distinct from the andesitic melt in pockets, the latter resulting from in situ amphibole breakdown. The melt in veins records the extraction and onset of migration of a silicic melt with high- $\mathrm{Nb}$ and adakitic affinities (high $\mathrm{SiO}_{2}=54.2$ to 62.7 wt. $\%$ and high LREE contents $(\mathrm{La} / \mathrm{Yb})_{\mathrm{N}}=2.6$ to 68.5$)$. Adakite-like melts are believed to have been produced at conditions of $1000-1200^{\circ} \mathrm{C}$ and $2-3 \mathrm{GPa}$ from a subducting slab, and injected in the lithospheric mantle where they triggered widespread pargasite melting at $1200^{\circ} \mathrm{C}$ and pressures above $0.7-1.1 \mathrm{GPa}$, below Moho depths. We suggest that this late stage metasomatic event is associated to the calc-alkaline volcanic suite that was active throughout most of the Miocene during the formation of the Pannonian Basin. This late stage event is also believed to have injected large amounts of $\mathrm{CO}_{2}$ in the lithosphere mantle.

\section{Introduction}

Quenched melts in the form of glasses have been extensively reported in mantle xenoliths from many locations worldwide; they commonly occur in veins as intergranular films and/or as pockets between the primary minerals, or as inclusions in primary mantle minerals (e.g., Coltorti et al., 1999; Yaxley and Kamenetsky, 1999; Beccaluva et al., 2001; Shaw et al., 2006;

Lu et al., 2015). The occurrence of glass provides important information on chemical and physical processes occurring in the lithospheric mantle, such as partial melting and metasomatism. Glasses in mantle xenoliths show a very wide range of compositions, from carbonate-rich melts (Coltorti et al., 1999; Delpech et al., 2004; Moine et al., 2004), to highly silicic melts (e.g., Wulff-Pederson et al. 1999). 
51 Different origins for glasses in mantle xenoliths have been proposed on the basis of

52 mineralogical observations, geochemical datasets and experimental results. Such melts have been interpreted either as agents or products of mantle metasomatism (e.g., Coltorti et al., 1999; Beccaluva et al., 2001; Neumann et al., 2002; Ionov et al., 2005), or the products of in situ incongruent melting of pre-existing minerals (e.g., Laurora et al., 2001) prior to or during entrainment of the xenoliths. There are also compelling evidence for the circulation of volatile-rich fluids that play a significant role as efficient metasomatic agents (e.g Szabó et al. 1996; Dawson 1984). Another alternative explanation is that the melts are the products of reaction between xenoliths and their host magma due to chemical disequilibrium (e.g., Shaw et al., 2006; Shaw and Dingwell, 2008; Miller et al., 2012) during their transport to the Earth's surface.

Embey-Isztin \& Scharbert (2001) and Bali et al. (2002) suggested that melt pockets in ultramafic xenoliths from the Bakony-Balaton Highland Volcanic Field (BBHVF, Western Hungary) formed by reactions between pre-existing mantle phases (clinopyroxene \pm amphibole) and metasomatic agents that were compositionally distinct from the host alkali basalts. The infiltrating melts were inferred to have originated from melting of previously metasomatized upper mantle during the Middle Miocene mantle upwelling (Huismans et al., 2002). Bali et al. (2002; 2008a; 2008b) and Szabó et al. (2009) also showed that migrating melts within the lithospheric mantle beneath the BBHVF have strong affinities with subduction-related melts/fluids or slab melts.

71 In this contribution, we present new major and trace element data on minerals and glass from 72 fifteen xenoliths from four different BBHVF locations (Szentbékkálla, Szigliget, Füzes-tó and 73 Mindszentkálla), two of which having never been published before in the literature for mantle 74 xenoliths (Füzes-tó and Mindszentkálla). This new dataset, together with textural features, 75 allows further constraining the origin of the metasomatic agents migrating through the 
lithospheric mantle beneath the Pannonian Basin and their chemical reactions with the host lithospheric mantle. Based on the results, two metasomatic and partial melting events are recognized. The source of the last metasomatic event is also constrained.

\section{Geological background}

\subsection{Geodynamic context}

The Pannonian Basin (PB) is located in Central Europe and is part of the CarpathianPannonian region (CPR). The PB is surrounded by the Carpathian fold and thrust belt to the east and north, and by the Alps to the west and Dinarides to the south (Fig.1).

The CPR is composed of the ALCAPA (ALpian-CArpathian PAnnonian) and the TiszaDacia tectonic units that are separated by a major shear zone, the Middle Hungarian Zone. The PB is a typical inter-arc basin (Embey-Isztin et al., 2001); nevertheless, it shows a number of features characteristic of rift zones, such as high heat flow, recent alkali basaltic volcanism, a thin crust and lithospheric mantle, and a doming asthenosphere (Spakman, 1990; Falus et al., 2007). The major driving forces that led to the formation of the Pannonian Basin ( $20 \mathrm{Ma}$ ) were the continuous subduction and roll-back on its eastern boundaries and the synchronous eastward extrusion of ALCAPA blocks (Kazmer and Kovacs, 1985) from the Alpine compressional belt (Csontos et al., 1992; Horvath, 1993; Fodor et al., 1999).

The Pannonian Basin has experienced several geodynamic events during Miocene to Pleistocene times (Bali et al. 2008): (1) an early extensional phase during Miocene, related to the roll-back of the subducting European plate (Csontos et al., 1992; Horvath, 1993), resulting in a lithospheric thinning over the entire basin; (2) a short-lived compressional event during late Miocene to Pleistocene (Fodor et al., 1999); and (3) a late extensional phase during the 
101 Plio-Pleistocene that affected the central part of the Carpathian-Pannonian region (Bada et al.,

102 1999; Huismans et al., 2002). An extensive volcanic activity followed this second rifting

103 phase ( $7.96 \pm 0.03$ to $2.61 \pm 0.03 \mathrm{Ma}$, Wijbrans et al. 2007) during which formed the Bakony-

104 Balaton Highland Volcanic Field (BBHVF).

105

106 2.2 The Bakony-Balaton Highland Volcanic Field (BBHVF)

107

108 The Bakony-Balaton Highland Volcanic Field (BBHVF) is situated in the northern part of the

109 Lake Balaton (western Hungary, Fig.1). It is a well-studied young volcanic area on the

110 southern margin of the ALCAPA microplate, which is located in the center of the Carpathian-

111 Pannonian region and in the central southeastern part of the ALCAPA mega unit (Bali et al.

112 2008). The BBHVF itself has more than 50 basaltic volcanoes in a relatively small (around

$1133500 \mathrm{~km}^{2}$ ) area (Martin et al., 2003; Kereszturi et al., 2011). The volcanic centers of the

114 BBHVF were active between 7.96 Ma and 2.61 Ma (Balogh and Pécskay, 2001; Balogh and

115 Németh, 2005; Wijbrans et al., 2007; Szabó et al., 2010) and produced mostly alkali basaltic

116 volcanics (Szabó et al., 1992; Embey-Isztin et al., 1993). The Szigliget, Mindszentkálla and

117 Füzes-tó volcanic events are respectively dated at 4.2-3.9 Ma, 2.8-2.6 Ma and 2.6 Ma. The

118 age of the Szentbékkálla volcanic event is not known.

119 Ultramafic xenoliths can be found in basanitic lava flows and pyroclastic products at six

120 locations (Tihany, Bondoró Hill, Füzes-tó, Szentbékkálla, Mindszentkálla, and Szigliget).

121 Most xenoliths are spinel-bearing lherzolites; however, spinel-bearing harzburgites,

122 clinopyroxenites, orthopyroxenites, wehrlites, websterites and more rarely, composite

123 xenoliths were also found. The lithospheric mantle beneath the BBHVF is more deformed

124 than the known mantle portions on the edges of the Carpathian-Pannonian region (Downes et

125 al., 1992; Szabó et al., 1995). The most common textural type in peridotites is equigranular 
127 with protogranular, porphyroclastic and poikilitic are rarer. The peridotite xenoliths contain

128 olivine (ol), orthopyroxene (opx), clinopyroxene (cpx) and spinel (sp) as primary minerals.

129 The equilibrium temperatures of BBHVF mantle xenoliths vary between 880 and $1090{ }^{\circ} \mathrm{C}$

130 (Downes et al., 1992; Szabó et al., 1995; Bali et al., 2002; Kovacs et al., 2012). Using the

131 geotherm of Kovacs et al. (2012), the sampling depths represent a mantle column of about 33

132 to $56 \mathrm{~km}$ and correspond to pressures between 0.95 and $1.60 \mathrm{GPa}$.

133 The occurrence of middle and lower crustal xenoliths in the BBHVF are also described by

134 Szabó et al. (2010) and references therein. These crustal xenoliths were brought to the surface

135 by the BBHVF alkali volcanism. These granulites are composed of clinopyroxenes,

136 plagioclases, garnets \pm orthopyroxenes \pm amphiboles (Török et al., 2005).

137

138

139

140

141

142

143

144

145

146

147

148

149

150

3.1 Petrography of the mantle xenoliths

More than 150 ultramafic xenoliths from the BBHVF (Szentbékkálla, Szigliget, Füzes-tó and Mindszentkálla) were collected. After observation by optical microscopy, six ultramafic xenoliths from Szentbékkálla, four from Szigliget, three from Füzes-tó and two from Mindszentkálla were selected for geochemical analyses (Table 1).

Selected samples are 7 to $18 \mathrm{~cm}$ in diameter, except one smaller sample from Mindszentkálla ( $2.5 \mathrm{~cm}$ in diameter). Xenoliths are composed of ol, opx, cpx and sp as primary minerals.

Point-counting analyses (400 points) indicate that most xenoliths are spinel-bearing peridotites $(n=13)$, ten of which are lherzolites and three are harzburgites (Fig. 2). The Cpx modal composition varies from 1.8 to 4 wt. $\%$ in harzburgites and from 6 to 18.5 wt. $\%$ in 
151 lherzolites. Two samples (SZB51 and SZB66) were classified as cpx-poor lherzolites (<10\%

$152 \operatorname{cpx})$.

153 Based on the classification of Mercier \& Nicolas (1975), the xenoliths show either

154 protogranular or equigranular microstructures. Samples with a protogranular microstructure

155 display coarse grain sizes $(2-6 \mathrm{~mm})$, whereas those with equigranular microstructure are fine-

156 grained (1-2 mm). Protogranular samples have grains of olivine and orthopyroxene with

157 heterogeneous sizes $(<1$ to $5 \mathrm{~mm})$ and show curvilinear grain boundaries and vermicular

158 spinels. Most samples with an equigranular microstructure refer to the mosaic subtype variety

159 (SZB44, SZB50, SZG30, FT12) and one has a tabular texture (FT08P). In these xenoliths,

160 grains have straight grain boundaries and they very often show triple junctions with angles at

$161120^{\circ}$. Spinel (and amphibole in FT08P) may be abundant in these samples (up to 12 vol. \%)

162 and it occurs as an interstitial (frequently) sub-euhedral mineral forming alignments of spinel

163 aggregates. Two samples (SZG14, SZG44) display an intermediate microstructure grading

164 from a protogranular to an equigranular texture. Some also display poikilitic features marked

165 by poikilitic olivine enclosing opx or poikilitic opx enclosing olivine (Fig. 3b). There is no

166 relationship between microstructures and the cpx modal contents of the peridotites.

167 Amphibole also occurs in some xenoliths (Szigliget, Füzes-tó and Mindszentkálla), regardless

168 of the microstructure, as a secondary mineral disseminated between primary minerals (up to 7 169 vol. \%).

1713.2 Petrography of melt pockets and veins

172

173 All the xenoliths in this study bear mineralogical evidence of melt and fluid circulation in

174 both lherzolites and harzburgites such as fluid and silicate melt inclusions in primary minerals

175 (opx, cpx, ol) and silicate glass in veins or melt pockets (Fig. 3). Clinopyroxenes sometimes 
displays spongy rims when in contact with melt veins or melt pockets (Fig.3a). Spinel can

177 also display spongy rims but in lower abundance. Melt pockets (Fig. 3d, e, g, h) were observed in seven samples in SZB44, SZB50, SZB51, SZG23, SZG44 and FT12 lherzolites and in FT08P harzburgite. The size of silicate melt pockets is variable and ranges from few hundred microns up to few millimeters in diameter (similar to those described by Bali et al.,

181 2002). In most cases, they are connected to each other by a network of thin silicate melt veins

182 occurring at the contacts or cross cutting primary minerals. The shape of melt pockets is mostly irregular or it may have the shape of ghost minerals that have entirely broken down

184 (e.g. amphibole).

185 Melt pockets are composed of brownish glass (gl), in which euhedral to sub-hedral secondary

186 minerals crystallized such as olivine (ol-II), clinopyroxene (cpx-II) and spinel (sp-II), all

187 smaller than $0.3 \mathrm{~mm}$ in diameter. Most melt pockets also contain large vesicles (up to 0.5

$188 \mathrm{~mm}$ ) (Fig. 3d, g, h). In xenoliths SZG23, FT12 and FT08P, melt pockets are associated with

189 resorbed amphibole (amp-I). In this case, a resorbed amphibole crystal is often observed in

190 the center of the pockets, surrounded by silicate glass and secondary minerals mentioned

191 above. Some melt pockets are entirely composed of glass.

192 Melt veins (Fig. 3c) are observed in all samples and are mainly located at grain boundaries 193 between primary minerals or cross-cut the primary mineralogy. The size of melt veins is

194 variable (few tens of microns to $0.4 \mathrm{~mm}$ ) and they are mainly composed of brownish glass

195 and large vesicles (Fig. 3c), where ol-II, cpx-II, sp-II are present in lower abundance

196 compared to melt pockets.

197

$198 \quad 3.3$ Petrography of silicate melt and fluid inclusions 
Silicate melt inclusions (SMI) were only observed in the SZG14 lherzolite. They occur as 201 primary inclusions (Roedder, 1984) in the rim of a clinopyroxene (Fig. 3a). The size of the primary SMI are 40, 60 and $100 \mu \mathrm{m}$ in diameter and their shape is spherical. The SMIs consist of brownish glass (50-70 vol. \%), one $\mathrm{CO}_{2}$-rich retraction bubble (10-25 vol. \%) and tiny not identified mineral phases (10-40 vol. \%).

Fluid inclusions are present by order of abundance (i.e. number of inclusions per unit volume of hosting mineral) in Opx, Cpx and Ol. They occur along healed fractures that crosscut the entire host crystal (Fig. 3f) as already described in the BBHVF by Bali, et al., (2008).The fluid inclusions display negative crystal shapes or have rounded shapes with sizes varying between 5 and $60 \mu \mathrm{m}$. At room temperature, the fluid inclusions contain one (liquid) or two

210 (liquid + vapor) phases. Using the definition of Roedder (1984), the inclusions can be 211 classified as secondary fluid inclusions.

\section{Geochemistry}

\subsection{Analytical methods}

4.1.1 Major and volatile element analyses

Electron microprobe analyses (EMPA) of mantle minerals, melt pockets and veins were carried out on a CAMECA SX FIVE at CAMPARIS (Jussieu, Paris, France). Minerals were analyzed with a focused beam (1-2 $\mu \mathrm{m})$, a beam current of $20 \mathrm{nA}$ and a counting time of $10 \mathrm{~s}$ for each element on peak and $10 \mathrm{~s}$ on background. Vanadium was determined with a beam current of $300 \mathrm{nA}$ in all minerals. Glass was analyzed with a $10 \mathrm{nA}$ defocused beam $(10 \mu \mathrm{m})$

224 and a counting of $10 \mathrm{~s}$ on the peak and $10 \mathrm{~s}$ on the background. The concentrations of $\mathrm{S}, \mathrm{Cl}$ 
and $\mathrm{F}$ were determined with a $45 \mathrm{nA}$ defocused beam and a counting time of $100 \mathrm{~s}$ on peak.

226 Accuracy was checked against standards (albr, phn9, ortr, apat, mnti, baso, sca2 and $\mathrm{Fe}_{2} \mathrm{O}_{3}$ ).

227 Detection limits are $<50 \mathrm{ppm}$ for $\mathrm{S},<60 \mathrm{ppm}$ for $\mathrm{F},<100 \mathrm{ppm}$ for $\mathrm{Cl},<300 \mathrm{ppm}$ for $\mathrm{P}$ and

$228<1000$ ppm for other major elements.

\subsubsection{Trace element analyses}

Clinopyroxene, amphibole, and glass in melt pockets and veins were analyzed for trace elements by laser ablation LA-ICP-MS, using a $193 \mathrm{~nm}$ ArF laser ablation system (Photon Machine Analyte G2) coupled to an ICP-QMS (Varian 800-MS) at the Laboratoire de Planétologie et de Géodynamique (LPGN, Nantes, France). Cpx and amphibole were analyzed using a laser repetition rate of $5 \mathrm{~Hz}$, a pulse energy of $6 \mathrm{~mJ}$, a 65 to $85 \mu \mathrm{m}$ laser spot diameter, corresponding to a fluence between 4.08 and $7.26 \mathrm{~J} / \mathrm{cm}^{2}$. Glass in melt pockets and veins was analyzed using identical pulse frequency and energy, but with a 20 to $50 \mu \mathrm{m}$ laser spot diameter (fluence of $5.45 \mathrm{~J} / \mathrm{cm}^{2}$ ). The background was measured for $30 \mathrm{~s}$ before ablation and each analysis lasted for about $90 \mathrm{~s}$. Measurements were calibrated against NIST 612 glass standard (Gagnon et al., 2008), using $\mathrm{CaO}$ for $\mathrm{Cpx}$ and amphibole, and $\mathrm{Al}_{2} \mathrm{O}_{3}$ for glass as

242 internal standards (measured by EMPA). Reproducibility and accuracy were characterized 243 using the BCR-2G international standard, which was analyzed at the beginning and end of 244 each run as well as every series of 10-15 unknown analyses. The analytical reproducibility is 245 better than 5\% except for $\mathrm{Cr}$, Th and $\mathrm{U}$, which are better than $10 \%$. Data reduction was 246 performed using the Glitter software (Achterberg et al., 2001). 
4.2.1 Major element analyses

252 No significant major element zonation was observed between cores and rims in the rock-

253 forming minerals of peridotites from Szentbékkálla, Szigliget, Füzes-tó and Mindszentkálla 254 (Table 2).

\subsubsection{Olivine}

Primary olivines in lherzolites have homogeneous compositions and relatively low $\mathrm{Mg}$ number (88.8-90.6). Their Mg-numbers are slightly higher in the spinel harzburgites (90.290.4) than in the other xenoliths. $\mathrm{NiO}$ contents in olivines from harzburgites and cpx-poor lherzolites vary from 0.33 to 0.41 wt. $\%$ and from 0.28 to 0.42 wt. $\%$ in the lherzolites. The Mg-numbers of secondary olivines (Ol II) in melt pockets are higher than those of primary olivines (89.7-92.7). Concentration of $\mathrm{CaO}\left(0.1-1.9\right.$ wt. \%), $\mathrm{Cr}_{2} \mathrm{O}_{3}(0.0-0.3$ wt. \%) and $\mathrm{Al}_{2} \mathrm{O}_{3}(0.0-0.22$ wt. \%) in secondary olivines are higher than those in the primary olivines (Table 3).

\subsubsection{Orthopyroxene}

The composition of orthopyroxene ranges from $\mathrm{En}_{90.2}$ to $\mathrm{En}_{91.3}$ in harzburgites and from $\mathrm{En}_{89.0}$

270 to $\mathrm{En}_{90.9}$ in the lherzolites. The $\mathrm{Al}_{2} \mathrm{O}_{3}$ contents (2.5-3.6 wt. \%) of orthopyroxenes in the 271 harzburgites and in the lherzolites (3.8-5.8 wt. \%) are variable; the $\mathrm{Cr}_{2} \mathrm{O}_{3}$ content is in the range of $0.0-0.1$ wt. \% in harzburgites and lherzolites orthopyroxenes (Table 2). 
276 Primary clinopyroxenes (Cpx I) are augites $\left(\mathrm{En}_{36.8-37.6} \mathrm{Wo}_{35.5-36.8} \mathrm{Fs}_{26.0-27.2}\right)$. Their $\mathrm{Mg}$-number 277 ranges from 88.0 to 91.0 in the lherzolite and from 90.7 to 92.5 in the harzburgites. Major 278 element contents of Cpx I in lherzolites are highly heterogeneous (Fig. 4) with higher $\mathrm{Al}_{2} \mathrm{O}_{3}$ 279 and $\mathrm{Na}_{2} \mathrm{O}$ and lower $\mathrm{CaO}$ content $\left(\mathrm{Al}_{2} \mathrm{O}_{3}\right.$ 5.3-8.0 wt. \%, $\mathrm{Na}_{2} \mathrm{O}$ 0.7-1.9 wt. \% and $\mathrm{CaO} 17-8$ 28021.6 wt. \%, respectively) than in harzburgites $\left(\mathrm{Al}_{2} \mathrm{O}_{3}\right.$ 2.2-4.1 wt. \%; $\mathrm{Na}_{2} \mathrm{O}$ 0.3-1.2 wt. \% and $281 \mathrm{CaO} 19.0-23.7$ wt. \%, respectively). Concentrations of $\mathrm{TiO}_{2}$ in $\mathrm{Cpx} \mathrm{I}$ are $<0.94$ wt. \% in 282 lherzolites and between 0.1-0.2 in harzburgites (Table 2). The $\mathrm{CaO}$ (18.3-21.7 wt. \%), $\mathrm{Al}_{2} \mathrm{O}_{3}$ (6.2-10.5 wt. \%) and $\mathrm{TiO}_{2}(0.2-2.8$ wt. \%) contents of secondary cpx (Cpx II, augites, En $40.7-$ 41.2 $\left.\mathrm{Wo}_{28.8-29.2} \mathrm{Fs}_{29.7-30.1}\right)$ in melt pockets are higher than those of the primary clinopyroxenes 285 for similar Mg-number (Fig.5, Table 3).

\subsubsection{Spinel}

The primary spinel displays large variations in composition ranging from magnesian and aluminous chromite (SZB16, SZB44, SZB50, SZB52, SZG14, SZG30, SZG44, FT12, MSZK1308) to chromite (SZB51, SZB66, SZG23, FT01P, FT08P, MSZK1306A). The Mgnumbers and Cr-numbers range from 59.6 to 78.1 and from 7.7 to 43.9 , respectively (Table 2, Fig. 4). The spinels in harzburgites are more chromiferous than in the lherzolites; the Mgnumber versus Cr-number diagram (Fig. 4) shows a linear distribution from low Cr-numberhigh Mg-number in spinels from the lherzolite to high Cr-number-low Mg-number in spinels

296 from harzburgites. Secondary spinels in reaction zones commonly have higher Mg-number 297 (65.9-82.4) and Cr-number (9.7-45.8) compared with primary spinel, corresponding to the 298 most chromiferous spinels of the harzburgites (Fig.5, Table 3). 
Amphiboles occur in four xenoliths (SZG30, FT12, FT08P, MSZK1306A, Table 3) and are pargasites according to the classification of Locock, (2014). Their Mg-numbers range from 88.2 to 89.0 and are similar to those described by Bali et al. (2002) and Szabó et al. (2004). They are variable in $\mathrm{TiO}_{2}\left(0.3-2.7\right.$ wt. \%) and rather rich in $\mathrm{Cr}_{2} \mathrm{O}_{3}\left(1.0-1.8\right.$ wt. \%) and $\mathrm{Na}_{2} \mathrm{O}$ (2.1-3.7 wt. \%). Amphiboles in MSZK1306A have lower $\mathrm{TiO}_{2}, \mathrm{Al}_{2} \mathrm{O}_{3}$ and $\mathrm{Na}_{2} \mathrm{O}$ contents and higher $\mathrm{CaO}, \mathrm{SiO}_{2}$ and $\mathrm{K}_{2} \mathrm{O}$ contents than resorbed amphiboles in reaction zones (SZG30, FT12, FT08P).

\subsubsection{Carbonates}

Carbonates were analyzed in veins in lherzolite SZG30. They have compositions typical of Mg-calcites (CaO between 50.7 and 52.6 wt. \%) with low $\mathrm{FeO}$ (1.61 to 1.99 wt. \%), $\mathrm{MgO}$ (4.36 to 5.02 wt. \%), $\mathrm{MnO}$ (0.31 to 0.51 wt. \%) and $\mathrm{SiO}_{2}(0.02$ to 0.07 wt. \%).

In summary, primary minerals $(\mathrm{Ol}, \mathrm{Opx}, \mathrm{Cpx}, \mathrm{Sp})$ show the same range of major element 317 compositions as those published in previous studies for xenoliths from Szentbékkálla and Szigliget (Downes et al., 1992; Bali et al., 2002; Falus et al., 2004; Demény et al., 2004; Bali et al., 2007; Szabó et al., 2009) (Fig.4). However, some samples display more fertile compositions than those from previous studies, as shown by the lower Mg-numbers (e.g. samples SZB44, SZB50, SZG30, SZG44 and FT12) in olivine (88.8-89.3), orthopyroxene (89.2-90.0) and clinopyroxene (88.8-90.4). Similar major element compositions of secondary minerals were previously reported by Bali et al. (2008) in melt pockets from mantle xenoliths form Szentbékkálla (Fig. 5). 
4.2.2 Trace element analyses

The rare-earth elements (REE) concentrations of mineral phases (clinopyroxene, amphibole) are given in Table 4 and REE and trace element patterns are presented in Figure 6. Trace element contents of clinopyroxenes correspond to cores of primary clinopyroxenes (Cpx I) to avoid potential metasomatic modification.

The lherzolites have clinopyroxenes with very variable trace element contents and were subdivided into three groups on the basis of the shape of their REE patterns and on the light

334 REE (LREE)/Heavy REE (HREE) ratios, as follows.

335 Group I. Clinopyroxenes are characterized by low abundances of LREE compared with 336 MREE and HREE (SZB16, SZG14, SZG30, SZG44, MSZK1308, Fig. 6). The lherzolites in 337 which they occur have a protogranular texture (except SZG30). The $(\mathrm{La} / \mathrm{Yb})_{\mathrm{N}}$ (where $\mathrm{N}$ 338 indicates primitive mantle normalized) ratios are low and range from 0.2 to 0.8 . The 339 multielement patterns display low contents in highly incompatible elements. A slight 340 enrichment in $\mathrm{Nb}$ is observed on MSZK1308. There are negative anomalies in $\mathrm{Ba}, \mathrm{Zr}$ and $\mathrm{Ti}$ 341 and a slight Pb negative anomaly in SZB16, SZG30, MSZK1308. The concentration of Sr in 342 this group ranges from 56.9 to $90.0 \mathrm{ppm}$ (Table 4).

343 Group II. Clinopyroxenes from group II are characterized by flat or nearly flat REE patterns 344 (SZB44, SZB50, SZB52). They are found in lherzolites with equigranular mosaic textures 345 (except SZB52). These clinopyroxenes have $(\mathrm{La} / \mathrm{Yb}) \mathrm{N}=0.6-1.3,(\mathrm{La} / \mathrm{Sm}) \mathrm{N}=0.8-1.0$ and $346(\mathrm{Sm} / \mathrm{Yb}) \mathrm{N}=0.6-1.5$ with weak negative anomalies in $\mathrm{Nb}, \mathrm{Zr}$ and $\mathrm{Ti}$ and no enrichment in the 347 most incompatible elements (Th and U). The concentration of $\mathrm{Sr}$ in this group ranges from $348 \quad 21.4$ to $71.9 \mathrm{ppm}$. 
Group III. Clinopyroxenes from group III are characterized by REE or trace element patterns

350 showing enrichments in the most incompatible trace elements (SZB51, SZB66, SZG23, FT12,

351 FT01P, FT08P, MSZK1306A), and therefore high $(\mathrm{La} / \mathrm{Yb})_{\mathrm{N}}$ ratios ranging from 0.7 to 15.7.

352 Their trace element patterns show enrichments in large ion lithophile elements (LILE Th and

$353 \mathrm{U}$ ) and negative anomalies in Ba and high field strength elements (HFSE; Ta, $\mathrm{Zr}$ and Ti)

354 except $\mathrm{Nb}$. The concentration of $\mathrm{Sr}$ in group III ranges from 36.9 to $182 \mathrm{ppm}$. Finally, the

355 microstructure in group III lherzolites range from protogranular to equigranular mosaic. The

356 harzburgites have clinopyroxenes with very variable trace element contents and are

357 characterized by low abundances of HREE and variable MREE and LREE abundances. All

358 the HREE depleted clinopyroxenes are in the group III (SZB51, SZB66, FT01P, FT08P,

359 MSZK1306A).

361 REE and other trace element patterns of the amphibole in harzburgite MSZK1306A and

362 FT08P (Fig. 6) are similar to those of clinopyroxene from the same sample (group I).

363 However, amphiboles in sample MSZK1306A have a higher concentration in most trace

364 elements such as U, Th and Sr (U 0.1 ppm, Th 0.6 ppm and Sr 107.1-115.6 ppm; in

365 MSZK1306A and U 3.0-3.4 ppm, Th 13.9-15.3 ppm and Sr 472.9-513.2 ppm in FT08P) than

366 in the coexisting clinopyroxene (U 0.0 ppm, Th 0.2 ppm and Sr 36.9-39.4 ppm; in

367 MSZK1306A and U 1.5-2.0 ppm, Th 5.3-7.5 ppm and Sr 121-144 ppm in FT08P), in

368 agreement with observations in amphibole-bearing xenoliths from Antarctica (Coltorti et al.,

369 2004) and Kapfenstein (Coltorti et al., 2007).

$371 \quad 4.3$ Chemistry of the melt phases

373 4.3.1 Major element analyses 
375 Glasses show very variable compositions (Table 5, Fig.7) and will be subdivided into three 376 groups on the basis of their petrographic textures and of their major element contents, as 377 follows.

378 Group I. The glasses in melt veins. The major element compositions of glass in melt veins are 379 highly variable both between and within single xenoliths. Overall, they are characterized by 380 relatively high $\mathrm{SiO}_{2}\left(55.8-62.7\right.$ wt. \%) and $\mathrm{K}_{2} \mathrm{O}$ (1.6-5.9 wt. \%) and low $\mathrm{Na}_{2} \mathrm{O}$ (3.9-5.7 wt. $381 \%), \mathrm{Al}_{2} \mathrm{O}_{3}\left(17.0-20.4\right.$ wt. \%), $\mathrm{MgO}\left(2.4-4.2\right.$ wt. \%) and $\mathrm{FeO}_{\mathrm{T}}(2.5-4.3$ wt. \%) contents (Fig. $3827)$.

383 Group II. The glasses in silicate melt inclusions. The major element compositions of glass in 384 silicate melt inclusions are characterized by relatively high $\mathrm{SiO}_{2}\left(55.0\right.$ wt. \%), $\mathrm{Na}_{2} \mathrm{O}(7.31$ wt. $\%), \mathrm{Al}_{2} \mathrm{O}_{3}\left(22.9\right.$ wt. \%), and low $\mathrm{FeO}_{\mathrm{T}}\left(3.3\right.$ wt. \%), $\mathrm{MgO}\left(2.3\right.$ wt. \%) and $\mathrm{K}_{2} \mathrm{O}(<1.8$ wt. \%) contents (Fig. 7).

387 Group III. The glass in melt pockets. The major element compositions of glass in melt pockets are highly variable both between and within single samples. Overall, they are characterized by relatively low $\mathrm{SiO}_{2}\left(50.8-57.2\right.$ wt. \%), $\mathrm{Na}_{2} \mathrm{O}$ (4.0-5.5 wt. \%), high $\mathrm{Al}_{2} \mathrm{O}_{3}$ (19.5-23.8 wt. \%) and $\mathrm{FeO}_{\mathrm{T}}$ (3.0-4.9 wt. \%) contents (Fig. 7) compared with group I and II.

394 The trace element concentrations of glass phases are given in Table 6 and REE and their 395 patterns are shown in Figure 8. The glasses present very variable trace element contents and were subdivided into two groups on the basis of their location and their trace element contents, as follows. 
398 Group I. The glass in melt veins and silicate melt inclusions. Glasses are characterized by

399 REE or other trace element patterns showing enrichments in the most incompatible trace 400 elements (SZB16, SZB51, SZB52, SZB66, SZG14, FT01P, Fig. 8a) and therefore high

$401(\mathrm{La} / \mathrm{Yb}) \mathrm{N}$ ratios ranging from 2.6 to 68.5 . Glass in melt veins have trace element patterns

402 similar to glass analyzed by Szabó et al. (2009) in silicate melt inclusions.

403 Group II. The glasses in melt pockets present very variable trace element contents and were 404 subdivided into two sub-groups on the basis of their trace element contents, as follows.

405 Group IIa. Glasses from group IIa are characterized by flat or nearly flat REE patterns 406 (SZB44, SZB50, SZG44). These glasses have $(\mathrm{La} / \mathrm{Yb})_{\mathrm{N}}=0.1-1.6,(\mathrm{La} / \mathrm{Sm})_{\mathrm{N}}=0.1-1.2$ and $407(\mathrm{Sm} / \mathrm{Yb})_{\mathrm{N}}=1.0-1.4$ with positive anomalies in $\mathrm{Nb}, \mathrm{Sr}$ and $\mathrm{Ti}$ and a negative anomaly in $\mathrm{Zr}$, 408 Hf.

409 Group IIb. Glasses from group IIb are characterized by REE or trace element patterns 410 showing enrichments in the most incompatible trace elements (SZG23, FT12, FT08P), and 411 therefore high $(\mathrm{La} / \mathrm{Yb})_{\mathrm{N}}$ ratios ranging from 6.2-53.0. Their trace element patterns show 412 enrichments in LILE (Th and $\mathrm{U}$ ) and negative anomalies in HFSE ( $\mathrm{Nb}, \mathrm{Ta}, \mathrm{Zr}$ and Ti). The 413 MREE-HREE pattern is almost flat and resembles that of group I or group IIa glasses.

414 Glasses in melt pockets (Group IIa, IIb, Fig.3) present incompatible element enrichments that 415 parallel those of the associated amphiboles, and those described in the Pannonian Basin 416 (Demény et al. 2004; Demény et al. 2005; Bali et al., 2008).

418 4.4 Bulk melt pocket compositions

420 Bulk compositions of melt pockets have been reconstructed from modal composition and 421 from the chemistry of the glasses and the secondary mineral phases that compose them. The 422 results are presented in Table 7 for one sample of Szentbékkálla, one of Szigliget and one of 
423 Mindszentkálla. The reconstructed bulk compositions of the silicate melt pockets are very

424 similar to pargasitic amphibole compositions and to the analyzed amphiboles in the respective 425 locations.

\subsection{Thermobarometry}

Equilibrium temperatures of the studied xenoliths were determined using the 'Ca-in-opx' and 'opx-cpx' thermometers of Brey et al. (1990), using a pressure of 1.5 GPa. All xenoliths show moderate equilibrium temperatures (Szentbékkálla: $960-1080^{\circ} \mathrm{C}$; Szigliget: $990-1010^{\circ} \mathrm{C}$;

Füzes-tó: $960-1090^{\circ} \mathrm{C}$; and Mindszentkálla: $930-1030^{\circ} \mathrm{C}$ ). These results are similar to those of mantle xenoliths published from the same volcanic field (BBHVF) (Szabó et al., 1995; Bali et al., 2002; Szabó et al., 2009). The equilibrium temperatures vary with the microstructure of the xenoliths. Xenoliths with coarse-grained protogranular microstructure record high equilibrium temperatures $\left(930-1090^{\circ} \mathrm{C}\right)$ whereas xenoliths with a mosaic microstructure record lower equilibrium temperatures $\left(930-993^{\circ} \mathrm{C}\right)$, consistent with the recent study of

438 Embey-Isztin et al. (2014). According to the geotherm of Kovacs et al. (2012), the mantle 439 section sampled represents depths of 35 to $50 \mathrm{~km}$.

\section{Discussion}

443 The peridotite xenoliths from the BBVHF record a complex multi-stage partial melting and 444 metasomatic history, such as demonstrated by Bali et al. (2002, 2008) and Downes et al. 445 (1992). The following discussion will mostly focus on the origin of the latest metasomatic 446 imprint in the four xenolith suites. The mineralogical and geochemical evidences for earlier 447 processes are briefly described below. 
4495.1 Processes recorded before the late stage metasomatism

5.1.1 Partial melting of the peridotite

The major element compositions of the primary mineral phases in six protogranular samples of the suite show high Mg\# or $\mathrm{Cr} \#(\mathrm{Ol}, \mathrm{Opx}, \mathrm{Cpx} \mathrm{Sp})$ associated to a low modal content of clinopyroxene (4-9 vol.\%), low contents of basaltic components in the primary clinopyroxene and low HREE contents in clinopyroxenes. These mineralogical and geochemical characteristics indicate that some samples have recorded variable, yet high partial melting degrees in the lithospheric mantle beneath the Pannonian Basin. Some xenoliths (SZB66, MSZK1306A, FT01P and FT08P) have low Dy, Er, Yb and Lu contents compared with the CI-chondrite and primitive mantle estimates (Fig. 6) and have preserved the trace element signature of partial melting residues. To assess the extent of partial melting, we used the nonmodal fractional partial melting model of Johnson et al. (1990) and Hellebrand et al. (2002) in the spinel stability field (see supplementary material). Two harzburgites (MSZK1306A and FT08P) and two lherzolites from Szentbékkálla (SZB52 and SZB66) indicate moderate to

465 high melting degrees of $\approx 10-15 \%$, in accordance with their low cpx modal contents $(1.75-9$ vol.\%) and the low basaltic components of their cpx. The occurrence of peridotites showing evidence of moderate to high partial melting degree (until $25 \%$ ) has been already described in 468 the BBHVF (Bali et al. 2002, 2008 for Szentbékkálla and Downes et al., 1992 for Szigliget 469 and other locations in the BBHVF).

470 However, there is a discrepancy between mineralogical and geochemical indicators in some 471 cases. One of the lherzolites (SZB52) and one of the harzbugites (FT08P) show lower melting 472 degrees of $\approx 5-10 \%$ and have low Cr\# in spinel (16.7-18.5 wt. \%). In case of FT08P this is 
473 incompatible with the low cpx modal content of the harzburgite $(2.3$ vol. $\% ; \approx 20 \%$ melting $)$. In

474 the SZB52 lherzolite the cpx modal content is very high (18.5 vol.\%). Since these samples

475 show enrichments in the most incompatible elements, their HREE contents may not simply

476 represent melting residues, but were also likely re-enriched due to metasomatic overprint.

477 Some protogranular lherzolites (SZB16, SZG14, SZG44, MSZK1308) from Szentbékkálla,

478 Mindszentkálla and Szigliget have fertile compositions with minerals with low Mg\# and Cr\#,

479 high modal contents of cpx (12-18 vol.\%), high amounts of basaltic components in their cpx

480 as well as slightly LREE depleted REE patterns. Major and trace element compositions for

481 these samples are very similar to Primitive Mantle values (McDonough and Sun, 1995). These

482 mineralogical and geochemical characteristics suggest that these samples suffered from very

483 low degrees of melting. Most of these samples also have high HREE compared to those of the

484 primitive cpx used in the trace element modeling (taken from Johnson et al., 1990), which

485 suggest that if these samples melted, the melting degree was low enough $(<1 \%)$ not to affect

486 the HREE contents but only the most incompatible LREE.

$488 \quad$ 5.1.2 Metasomatism

490 Metasomatic processes have also affected the xenoliths prior to the formation of melt pockets

491 and veins. The occurrence of amphibole is widespread in the lithospheric mantle below the

492 BBHVF (Bali et al. 2002, 2008) and has been interpreted as a crystallization from volatile-

493 bearing silicate melt possibly linked to the percolation of subduction zone melts during the

494 Miocene. The trace element patterns in primary clinopyroxenes from most xenoliths

495 (lherzolites and harburgites) also show enrichments in the most incompatible elements (Th, U,

496 Ba, LREE) that were acquired during metasomatism. Lherzolites SZB51, SZG23, FT12,

497 FT08P have clinopyroxenes with selective enrichments in Th, U, LREE and depletions in 
HFSE. The gradual enrichments in the most incompatible elements can result from metasomatic imprint during chromatographic-like effects produced during interaction between the host peridotite and small melt fractions of a silicate melt enriched in trace elements (Bodinier et al., 1990). These trace elements characteristics in clinopyroxenes have also been interpreted as resulting from metasomatism by carbonate-rich melts below the BBHVF (Embey-Isztin et al., 2014). These enrichments are mostly seen in lherzolites with a mosaic microstructure that equilibrated at shallow depth below the MOHO $(\sim 30 \mathrm{~km}$, Posgay et al. 1995). The metasomatic overprint is also more pronounced in clinopyroxenes from harzburgites with enrichments in MREE and HREE, a characteristic feature of SZB51, SZB66, MSZK1306A and FT01P.

5.2 Late stage metasomatism

Textural observations in the studied BBHVF xenoliths indicate that trails of secondary fluid

512 inclusions, glass veins and glass pockets form a common network of melt circulation (Fig. 3d,

513 Creon et al., this volume). Moreover, as shown by Creon et al. (this volume), vesicles trapped

514 in melt veins and melt pockets and FIs are composed almost exclusively of $\mathrm{CO}_{2}$. The $\mathrm{CO}_{2-}$

515 rich character of percolating melts has previously been highlighted by the observation of

516 carbonates in veins and melt pockets in some xenoliths of the BBHVF (Embey-Isztin and

517 Scharbert, 2001; Bali et al., 2002; Demény et al., 2004; Demény et al., 2010). However, only 518 few carbonates were recognized in this study (SZG30). Seven xenoliths from three locations 519 (SZB44, SZB50, SZB51, SZG23, SZG44, FT12, FT08P; Table 1) display the development of 520 reaction zones at the expense of amphibole (Fig. 3g, h). Theothers (SZB16,SZB52, SZB66, 521 SZG14, SZG30, FT01P, MSZK 1306A, MSZK1308, Table 1) display glass in veins between 
primary minerals, commonly associated with newly formed minerals (olivine, clinopyroxene and spinel) that have higher Mg\# than the primary minerals (Fig. 9).

The amphibole-bearing harzburgite FT08P probably illustrates a primordial stage for melt pocket formation. The textural features in FT08P (Fig. 9) indicate that a melt was formed by incongruent breakdown of amphibole, due to heating or infiltration of a melt/fluid in the xenolith, according to the following reaction (Ban et al., 2005):

amphibole + melt $_{1}+\mathrm{CO}_{2} \rightarrow$ olivine + clinopyroxene + spinel + melt $_{2}+\mathrm{CO}_{2}$

In other xenoliths (SZB44, SZB50, SZB51, SZG23, SZG44), the melt pockets only displays $\mathrm{gl}+\mathrm{ol}+\mathrm{cpx}+\mathrm{sp}+\mathrm{CO}_{2}$ but no relict amphibole. This observation suggests that amphibole may locally have fully reacted and broken down. These melt pockets are similar to those described by Bali et al. (2008) for lherzolites and websterites from Szentbékkálla and Szigliget or by Embey-Isztin \& Scharbert (2001). The occurrence of large empty vesicles also indicates that a gas phase formed at some stage during in-situ partial melting of the amphibole or was rather inherited from a $\mathrm{CO}_{2}$-supersaturated metasomatic agent. This idea is in agreement with the measured high abundance of dissolved volatiles in the trapped glass (veins and melt pockets) which are up to $4.25 \pm 0.27$ wt. $\% \mathrm{H}_{2} \mathrm{O}$ and $0.96 \pm 0.02$ wt. $\% \mathrm{CO}_{2}$ (Creon et al., this volume), corresponding to $\mathrm{CO}_{2}$-saturated melt at lithospheric conditions (0.69 to $\left.1.78 \mathrm{GPa}\right)$.

The glass in the melt pockets has variable major element compositions and vary from basaltic andesitic or basaltic trachy-andesitic to andesitic-trachyte in composition (53.7-58.4 wt. \% $\mathrm{SiO}_{2}$ ). The glass in veins has a comparably more silicic composition and is typically trachyandesitic (57.1-62.1 wt. \% $\mathrm{SiO}_{2}$ ). The glass in veins are also more homogeneous at the scale of the sample than the glass in melt pockets. Such variable major element compositions are frequent in glass from mantle xenoliths worldwide (e.g. Wulff-Pedersen et al., 1999; Coltorti 
et al., 2000). Wulff-Pedersen et al. (1999) interpreted silicic glasses as cogenetic melts

548 derived by infiltration-reaction-crystallization (IRC) processes (Vannucci et al., 1998), with

549 the (highly) silicic melts being derived by percolation-reaction-crystallization mechanisms

550 during metasomatism by an infiltrating silicate melt (host basalt) and preferential reaction

551 with orthopyroxene. However, similar melt compositions in the BBHVF xenoliths have been

552 attributed by several authors (e.g. Bali et al., 2007; Bali et al., 2008a,b) to metasomatic

553 imprints unrelated to the alkali host basalts. These authors proposed that melt pockets have

554 formed by the breakdown of former amphibole due to the introduction of a metasomatic melt

555 (Bali et al., 2007). In the following sections, the origin of melt veins and pockets will be

556 addressed based on geochemical and petrographic grounds.

557

$558 \quad 5.2 .1$ Glass in the melt pockets

559

560 Compared with the literature data on glass from xenoliths from the BBHVF, the glass in the

561 melt pockets analyzed in this study resembles the compositional spectrum of glasses

562 documented in Bali et al. (2002) for similar melt pockets in peridotites and pyroxenites from

563 Szentbékkálla (samples from SZB group, Fig.7). The SMI in pyroxenes from spinel-

564 lherzolites from Szigliget (Szabó et al., 2009) have comparable $\mathrm{SiO}_{2}$ (54.2 wt. \%) and other

565 major elements $(\mathrm{Al}, \mathrm{Ca}, \mathrm{Na})$ than in the glass analyzed in the melt pockets but have lower

$566 \mathrm{MgO}, \mathrm{FeO}$ and higher $\mathrm{K}_{2} \mathrm{O}$ contents $(5.3$ wt. \%). The glass in melt pockets is very different in

567 composition from the SMI reported by Bali et al. (2008) from Szigliget since the latter is Si-

568 rich (57.3-74.0 wt. \%) and has always low $\mathrm{MgO}$ (0-0.88 wt. \%), $\mathrm{FeO}(0.44-3.57$ wt. \%) and

$569 \mathrm{CaO}(0.69-3.06$ wt. \%). Most of the glass in melt pockets has lower contents of the most

570 incompatible elements than alkali basalts (Embey-isztin et al., 1993) and also than calc-alkali

571 volcanics (Harangi and Lenkey, 2007) in the area for similar $\mathrm{SiO}_{2}$ contents (50.5-77.9 wt. \%). 
572 Some of the major element variations in glasses in veins and melt pockets could be consistent

573 with a fractional crystallization process (e.g. $\mathrm{SiO}_{2}, \mathrm{MgO}, \mathrm{CaO}, \mathrm{FeO}$; Fig.7). The possible

574 cogenetic relationship between glass in veins and less silicic melt pockets was tested using

575 crystal fractionation modeling of olivine, clinopyroxene and spinel from a parental melt in the

576 reaction zones using the rhyolite-MELTS software (Gualda et al., 2012; Ghiorso and Gualda,

577 2015) including the $\mathrm{H}_{2} \mathrm{O}$ and $\mathrm{CO}_{2}$ contents of the melts. The starting compositions were taken

578 from the most primitive composition measured for SZG44 glass. The crystal fractionation

579 (CF) calculations for a crystallizing assemblage of $0.1 \% \mathrm{ol}+84.4 \% \mathrm{cpx}+15.6 \%$ sp at $970^{\circ} \mathrm{C}$

580 and $1.2 \mathrm{GPa}$ fit well some major elements in glass from veins $(\mathrm{CaO}, \mathrm{MgO}, \mathrm{FeO})$ for about

$58130 \%$ FC (Fig. 7). However, the model fails to explain the high $\mathrm{K}_{2} \mathrm{O}$ and the low $\mathrm{Na}_{2} \mathrm{O}$ and

$582 \mathrm{Al}_{2} \mathrm{O}_{3}$ concentrations of the glass in veins. Trace elements contents of the $\mathrm{Si}$-rich glass in

583 veins also argue against a cogenetic relationship with melt pockets by crystal fractionation

584 (Fig. 8). For example, the glass in the melt pockets and in the veins that have similar $\mathrm{SiO}_{2} \%$

585 display contrasting trace element patterns, one being smoothly enriched in the most

586 incompatible elements (veins) and one displaying a rather flat distribution of trace elements

587 with some pronounced "negative" anomalies in HFSE (Fig. 8). The absence of negative HFSE

588 anomalies in the glass from veins is difficult to reconcile with an origin by simple crystal

589 fractionation process of an assemblage of ol+cpx + sp from a glass in melt pockets that display

590 negative/positive anomalies of these elements ( $\mathrm{Nb}, \mathrm{Ta}, \mathrm{Zr}, \mathrm{Hf}, \mathrm{Sr}, \mathrm{Pb})$. We conclude that the

591 glass in veins does not in most cases evolve from the glass in melt pockets due to simple

592 fractional crystallization of secondary ol+cpx+sp.

593 We suggest that the glass in veins represents a $\mathrm{CO}_{2}\left(-\mathrm{H}_{2} \mathrm{O}\right)$ rich Si-rich melt, that infiltrated

594 the xenoliths and triggered melting of interstitial amphibole to form the secondary melt

595 pockets. This interpretation is supported by the very similar trace element patterns in some

596 glasses from melt pockets and coexisting resorbing amphibole (Fig. 10). The compositional 
spectrum of hybrid melts resulting from assimilation of amphibole into $\mathrm{Si}$ - and trace element-

598 rich melt such as that occurring in some veins is shown in Figure 10. The close resemblance

599 of hybrid melts with the glass in melt pockets suggests that the incongruent melting of

600 amphibole buffered most of the trace element contents of the glass in melt pockets, except the

601 HREE budget. For instance, sample FT08P has glasses with trace element compositions very

602 similar to the resorbed amphibole (Fig. 10). Furthermore, the calculated bulk major element

603 compositions of the melt pockets by inverting the fractional crystallization of

604 OlII+CpxII+SpII in the pockets are fairly similar to that of the amphibole in the xenoliths

605 (this study, Table 7; Bali et al., 2008). Therefore, the glass in melt pockets is believed to result

606 from incongruent melting of amphibole, triggered by the influx of a hot $\mathrm{CO}_{2}$-rich silica-rich

607 melt into the peridotites (similar to the glass in veins), and subsequent CF of newly formed

608 OlII, CpxII and SpII. This metasomatic agent was defined as a $\mathrm{CO}_{2}$ or aqueous-rich fluid

609 enriched in LILE or as a LREE-enriched silicate melt. The $\mathrm{Sr}-\mathrm{Nd}-\mathrm{Pb}$ isotopic data on glass in

610 similar melt pockets from other SZB xenoliths (Bali et al., 2002) are not consistent with those

611 of the host Pliocene and Quaternary alkali basalts but rather support a melt source containing

612 a slab-derived component, that may have reacted with the upper lithospheric mantle during

613 percolation. This study further demonstrates that the metasomatic agent was likely Si-rich,

614 and enriched in LILE, HFSE, LREE, and had high volatile contents such as $\mathrm{H}_{2} \mathrm{O}$ and $\mathrm{CO}_{2}$

615 (Creon et al., this volume).

616 The geothermometer of Putirka (2008) has been used on clinopyroxeneII-glass pairs that

617 show evidence for chemical equilibrium to estimate the temperature of clinopyroxene-melt

618 equilibration in the melt pockets. Calculated temperatures (Szentbékkálla: $1,210-1,250^{\circ} \mathrm{C}$;

619 Szigliget: $1,230-1,270^{\circ} \mathrm{C}$; Füzes-tó: $1,220^{\circ} \mathrm{C}$; Table 8 ) represent minimum temperatures for

620 the formation of melt pockets. Similar calculations for clinopyroxenes in melt pocket in other

621 xenoliths from the Szentbékkálla locality yield similar temperatures (1110 to $1200^{\circ} \mathrm{C}$ from 
Demény et al. (2004) and Bali et al. (2008)). This range is $150-350^{\circ} \mathrm{C}$ higher than the estimated equilibrium temperatures of the host peridotites and pyroxenites (Table 8 ). These temperature estimates suggest that the studied melt pockets formed at higher temperatures than equilibrium temperatures recorded by the primary mantle minerals, likely induced by hot Si-rich magma injection. Pressure estimates based on Putirka (2008) indicate a minimum pressure for melt pocket formation of 0.7-0.8 GPa for Szentbékkálla, 1.0-1.1 GPa for Szigliget and 0.8-1.0 GPa for Füzes-tó, corresponding to depths of 28-38 km (Fig. 11). Figure 11 shows the comparison of the pressures determined from primary mineral chemical equilibrium (M-I), fluid inclusions trapping pressures (FI), vesicles pressure at the last meltfluid equilibrium ( $\mathrm{CO}_{2}$-melt; Creon et al., this volume) and newly formed minerals chemical equilibrium in melt pockets (M-II). The figure 11 illustrates in Szentbékkálla samples that vesicles, fluid inclusions and secondary crystallization of melt pockets happened almost at the same pressure, at about $\sim 0.8 \mathrm{GPa}$. In Szigliget samples, vesiculation and secondary crystallization of melt pockets took place at the same pressure close to the MOHO $(\sim 1.0$ GPa). However fluid inclusions trapping seems to have happened at shallower depths $(\sim 0.5$ GPa), a result likely biased by fluid inclusions decrepitation (Creon et al., this volume). In Füzes-tó samples, secondary crystallization of melt pockets and fluid inclusions show the same pressure close to the MOHO ( 0.9 GPa), whereas vesicles have lower pressure ( $\sim 0.6$ $\mathrm{GPa}$ ), which can be the result of a late melt-fluid equilibrium before the melt quenching. The P-T conditions estimated for mineral-melt equilibrium in the melt pockets show that the melt pockets formed in the upper part of the lithosphere, close to the MOHO, and that this occurred outside the stability field of amphibole-bearing peridotite due to an increase in temperature after melt injection (Olafsson and Eggler, 1983; Niida and Green, 1999).

\subsubsection{Glass in veins}


648 The glass in the veins has variable but high $\mathrm{SiO}_{2}$ contents (54.2 to 62.7 wt. \%). The lowest 649 silica-rich glass in veins (SZB16, SZB52) has a composition similar to the richest silica glass 650 in melt pockets (55.8-59.0 wt. \%). According to petrographic observations, there is only little 651 evidence for reaction between primary minerals (CpxI and SpI) and the interstitial glass in 652 veins. Figure 12 evidences that the melt in veins cannot be associated to in-situ melting of 653 peridotites (Draper and Green, 1997). This observation suggests that the Si-rich glass was in 654 close equilibrium with the host spinel peridotites in which they are found.

655 The glass in veins has high $\mathrm{SiO}_{2}, \mathrm{MgO}$ and $\mathrm{K}_{2} \mathrm{O}$ contents and has trace element contents 656 enriched in the most incompatible elements, showing variable $\mathrm{Pb}$ negative/positive and $\mathrm{Sr}$ 657 positive anomalies but no relative depletion in HFSE (Fig. 13). The Si-rich glass in veins has 658 different major element compositions compared to the Pliocene alkali basalts and calc-alkali 659 volcanics (Fig. 12) and show differentiated compositions in terms of major elements. The 660 glass in veins also display different trace element abundances or ratios than the more mafic 661 alkali basalts and calc-alkali volcanics from the Pannonian Basin (Fig. 13).

662 They also do not display the typical geochemical characteristics of worldwide calc-alkali 663 magmas as seen in most pannonian calc-alkali volcanics (ie. high $\mathrm{Ba} / \mathrm{Nb}$, negative anomalies 664 in HFSE) but it resembles some of the calc-alkali volcanics of the Pannonian Basin (Fig. 13 665 and 15), especially from the Northern Pannonian Basin (NPB, 17-10 Ma, Harangi and 666 Lenkey, 2007). They are however distinctive given their higher $\mathrm{Nb}$ and Ti and lower HREE 667 contents (Fig. 13) but also their higher $\mathrm{SiO}_{2}$ and $\mathrm{Na}_{2} \mathrm{O}$ and lower $\mathrm{FeO}, \mathrm{CaO}$ than the NPB 668 (Fig. 12).

669 The occurrence of Si-rich melts as efficient metasomatic agents and their interaction with the 670 lithospheric mantle beneath the BBHVF has already been documented by Bali et al. (2007, 671 2008a, 2008b) for xenoliths from Szentbékkálla and Szigliget (samples SZB and SZG) and 
672 was also documented by Coltorti et al. (2007) for mantle xenoliths from the Kapfenstein

673 (Austria). In the BBHVF, there are mineralogical and geochemical evidences that the

674 lithospheric mantle was modified by percolation of Si-saturated melts. The occurrence of opx-

675 rich lithologies in peridotites as well as of Qz-bearing websterite veins/bands were interpreted

676 as resulting from the interaction between melts/fluids derived from subducted slab (Bali et al.,

677 2008) and the lithospheric mantle beneath the BBHVF. In the BBHVF, the silica richest glass

678 (54.2-62.7 wt. \% $\mathrm{SiO}_{2}$ ) occurs as primary silicate melt inclusions in pyroxenes (opx, cpx) as

679 well as interstitial glass in veins in pyroxenes-rich xenoliths (Qz-bearing websterite,

680 clinopyroxenite) or in peridotites (lherzolites, harzburgites) from Szigliget (Bali et al., 2008).

681 However, these primary SMI have lower $\mathrm{MgO}, \mathrm{CaO}$ and much higher $\mathrm{K}_{2} \mathrm{O}$ for 57.3-80.2 wt.

$682 \% \mathrm{SiO}_{2}$ compared to the glass in veins (54.2-62.7 wt. \% $\left.\mathrm{SiO}_{2}\right)$. Of particular interest, the

683 interstitial glass in veins reported by Bali et al. (2008) in the Qz-bearing websterite is much

684 more silicic (63.8-80.5 wt. \% $\left.\mathrm{SiO}_{2}\right)$ and more depleted in terms of most major elements

685 except $\mathrm{K}_{2} \mathrm{O}$. In terms of trace elements, the SMI in opx and cpx from Bali et al. (2008) have

686 quite similar LREE, MREE ( \pm HREE) but they have higher Th, U contents and pronounced

687 negatives anomalies in $\mathrm{Nb}, \mathrm{Ta}, \mathrm{Sr}$.

688 Bali et al., (2008) described several features of the trace element composition which resemble 689 those of adakites in silicate melt inclusions of Szentbékkálla and Szigliget. Oppositely, the 690 low Sr content of the silicate melt inclusions (74-116 ppm) and high K/Na ratios, and large 691 ion lithophile element (LILE) and LREE concentrations are not typical for adakites (4400 $692 \mathrm{ppm} \mathrm{Sr}$ ). These features were interpreted as resulting from (1) the presence of a mineral phase 693 that retains $\mathrm{Sr}$ in the source during slab melt generation, (2) incompatible trace elements of 694 the source and (3) small degrees of partial melting. In this study, several characteristics of the 695 major and trace element compositions of the glass in veins also resemble those of adakites, 696 especially the low-Si adakites as illustrated in Figures 12 and 14. For instance, the Si-rich 
697 glasses have high $\mathrm{MgO}$ and $\mathrm{CaO}$, high $\mathrm{La} / \mathrm{Yb}$ at low $\mathrm{Yb}$ contents, high $\mathrm{Sr} / \mathrm{Y}$ at low $\mathrm{Y}$ contents

698 (Fig. 14). However, as demonstrated for the lithospheric mantle beneath the BBHVF (Bali et

699 al. 2008), the silicic melts derived from subduction zones have probably reacted within the

700 lithospheric mantle before being trapped as SMI or silicate melt pockets in the host peridotites

701 so it is unlikely that they have preserved their original geochemical signature.

702 Rapp et al. (1999) showed in their experiments a range of melts produced by assimilation of

703 peridotite by adakitic melts in order to understand the geochemical changes during migration

704 of melts in the mantle wedge. Some of the vein glasses have major element compositions

705 close to the composition obtained by assimilation experiments in Rapp et al. (1999) (MgO,

$706 \mathrm{Na}_{2} \mathrm{O}, \mathrm{K}_{2} \mathrm{O}$ ). However $\mathrm{CaO}$ and $\mathrm{Al}_{2} \mathrm{O}_{3}$ are much higher in the glass in veins than in the

707 experiments (Fig. 12). The trace elements of the glass in veins are also comparable in terms of

$708 \mathrm{REE}+\mathrm{Y}, \mathrm{U}, \mathrm{Rb}, \mathrm{Ba}$ from the assimilation experiments, but have higher $\mathrm{Th}, \mathrm{Nb}$ and do not

709 display a relative enrichment in Sr. The high HFSE contents observed in the glass in veins

710 could be a geochemical characteristic of high-Nb basalts that are found associated with

711 adakites in subduction zones (Defant and Kepezhinskas, 2001), such as the in Northern

712 Pannonian Basin found in the area (Harangi and Lenkey, 2007). The experiments of Xiong et

713 al. (2005) and those of Foley et al. (2000) show that rutile dominates Nb and Ta budgets

714 during the partial melting of subducted oceanic crust and only rutile is able to cause strong

715 fractionation of $\mathrm{Nb}$ and $\mathrm{Ta}$ from other trace elements to produce a negative $\mathrm{Nb}-\mathrm{Ta}$ anomaly in

716 the derived liquid (see next section). The absence of negative anomaly in $\mathrm{Nb}$-Ta imply

717 therefore the absence of rutile as a stable phase during melting in the source region of these

718 melts and during interaction with the lithospheric mantle.

719 The trace elements in the glass in veins could allow to place some constraints on the P-T

720 conditions of the formation of the adakitic melts. The low HREE contents $(\mathrm{La} / \mathrm{Yb}>20)$ and $\mathrm{Y}$

$721(<18 \mathrm{ppm})$ suggests the presence of garnet in the source region (Castillo et al., 1999; Defant 
and Kepezhinskas, 2001). The high abundance of $\mathrm{K}_{2} \mathrm{O}$ in the melts also suggests a substantial

723

724

725

726

727

contribution of phlogopite. In figure 15, the postulated melt source is located below the lithosphere-asthenosphere boundary (LAB, 2.2GPa, Tašárová et al., 2009) above the Pannonian Basin (1000-1200 ${ }^{\circ} \mathrm{C}$ and 2.2-3 GPa, Fig. 15). These estimations are higher than those of Bali et al., (2008) for the melt source $\left(950-1050^{\circ} \mathrm{C}\right.$ and $\left.1.5-2 \mathrm{GPa}\right)$, which were determined using silicate melt pockets modified by amphibole assimilation. Our estimation is based on melt compositions unmodified by amphibole assimilation, and are thus more representative of the source of the metasomatic agent.

\subsection{Melt generation and migration in the Carpathian-Pannonian mantle}

In the Figure 15a, the different P-T conditions determined using geochemical thermobarometers of the different magma genesis events are shown together with mineral phase stability fields. The metasomatic agent was generated along a subduction geotherm, in contact with hotter asthenospheric mantle between 2-3 GPa. The metasomatic agent migrated from its source region to the primary lithospheric mantle mineral equilibrium area $\left(\mathrm{M}_{\mathrm{I}}\right)$, which we locate on the geotherm postulated by Kovacs et al. (2012) to react with the amphiboles and form SMPs. Melt-mineral equilibrium compositions in SMPs $\left(\mathrm{M}_{\mathrm{II}}\right)$ recorded minimum pressure/temperature conditions near present day Moho depths. The $\mathrm{M}_{\mathrm{II}} \mathrm{P}-\mathrm{T}$ region is located in the plagioclase equilibrium field, which is contradiction with our observations. We suggest that the minimum pressures estimated with the method of Putirka are underestimating true melt generation pressures which were more likely in the spinel stability field, at above 1.2-1.3 $\mathrm{GPa}$, within the pressure range of primary mineral equilibrium $\left(\mathrm{M}_{\mathrm{I}}\right)$. The $\mathrm{M}_{\mathrm{II}}$ area is located within the carbonate equilibrium field; which does not satisfy our observations and those of the literature (Bali et al., 2002; Demény et al., 2004; Demény et al., 2010) which illustrate the 
747 presence of free $\mathrm{CO}_{2}$ and potentially carbonates in the mantle xenoliths. We do not explain

748 this discrepancy between known thermodynamic phase equilibrium and our observations. The

749 determination of carbon phase stability is beyond the scope of this work and will not be

750 discussed further here.

751 The Si-rich melts percolating the lithospheric mantle of the BBHVF have strong affinities

752 with high-Nb adakites and are associated with subduction zone fluids. The high $\mathrm{CO}_{2}$ and $\mathrm{H}_{2} \mathrm{O}$

753 contents of Si-rich melts (Creon et al., this volume) are in favor of a hydrated and carbonated

754 pyrolith. Altered oceanic lithosphere and/or sediment melting are best candidates for

755 providing a significant carbon and hydrogen budget (Staudigel et al., 1989; Plank and

756 Langmuir, 1998) to subduction melts. Dehydration and decarbonation of eclogites and

757 metasediments on the subduction geotherm at pressures above $3 \mathrm{GPa}$ liberated volatile and

758 incompatible element-rich fluids that migrated towards the metasomatized mantle wedge (Fig.

759 15). The percolation of these primary fluids destabilized phlogopite and amphibole rich

760 peridotites to generate $\mathrm{CO}_{2}$-supersaturated $\mathrm{Nb}$-rich silicic melts that rapidly reached

761 asthenospheric temperatures. The injection of such hot Si-rich melts in the lithospheric mantle

762 in turn triggered the fusion of pargasite due to increased temperatures within the spinel

763 stability field. Amphibole melts of initial basaltic compositions fractionated into olivine,

764 clinopyroxene, spinel and andesitic melts before the system quenched on its way up to the

765 surface.

766

7676 Conclusion

768

769 Compositional and textural features of fifteen ultramafic mantle xenoliths from four different

770 localities (Szentbékkálla, Szigliget, Füzes-tó and Mindszentkálla) have been studied. They

771 contain trails of secondary fluid inclusions, primary silicate melt inclusions, veins and pockets 
of melts which allow reconstructing different stages of partial melting and metasomatism in

773 the lithospheric mantle:

774

1. The lithospheric mantle below the Pannonian Basin is highly heterogeneous and has recorded a history of high to low partial fusion events overprinted by cryptic and modal metasomatism involving the formation of widespread pargasitic amphiboles.

2. The melting of a $\mathrm{CO}_{2}$-rich subducting slab derived source produced high-Nb silicic melts of adakitic affinity. Melting conditions were comprised at temperatures between $1000-1200^{\circ} \mathrm{C}$ and pressures between 2 and $3 \mathrm{GPa}$, near the lithosphere-asthenosphere boundary. This silicic melt is found in mantle xenoliths as a network of glass veins enclosing large $\mathrm{CO}_{2}$ vesicles.

3. The silicic melt migrated into the lithospheric mantle and interacted with pargasitic amphiboles. The melting of amphiboles was triggered by temperature increase due to magma injection and the high $\mathrm{CO}_{2}$ abundances in melts. The P-T conditions for melting and crystal fractionation of amphibole melt pockets were of 0.7-1.1 GPa and $1200{ }^{\circ} \mathrm{C}$, near the Moho transition. The melt pockets are found in mantle peridotites as an assemblages of andesitic glass, $\mathrm{CO}_{2}$-vesicles and secondary olivine, clinopyroxene and spinel. Pargasite melts could be the parental magmas of the calc-alkaline suite of the Pannonian Basin.

\section{Acknowledgements}

This project was funded by IFP Energies nouvelles. Thank you to Csaba Szabó for his kindness help in the field and in the study of these mantle xenoliths. Herman Ravalojaona is acknowledged for his assistance during sample and thin section preparation. We are grateful to Carole La for her efficient help in LA-ICP-MS analyses of trace elements at LPG Nantes. 
Michel Fialin and Nicolas Rividi of the centre CAMPARIS at UPMC assisted for EPMA.

798

799

800

801

802

803

804

805

806

807

808

809

810

811

812

813

814

815

816

817

818

819

820

821

8 References

Achterberg V., E., Ryan C. G., Jackson S. E. and Griffin W. (2001) Data reduction software for LA-ICP-MS. In: Sylvester, P. (ed.) Laser Ablation ICPMS in Earth Science: Principles and Applications. Mineral. Assoc. Canada 29, 239-243.

Bada G., Hovath F., Gerner P. and Fejes I. (1999) Review of the present day geodynamics of the Pannonian Basin progress and problems. Geodynamics 27, 501-527.

Bali E., Falus G., Szabó C., Peate D. W., Hidas K., Török K. and Ntaflos T. (2007) Remnants of boninitic melts in the upper mantle beneath the central Pannonian Basin? Mineral. Petrol. 90, 51-72. Available at: http://link.springer.com/10.1007/s00710-006-0167-z [Accessed January 25, 2014].

Bali E., Szabó C., Vaselli O. and Torok K. (2002) Significance of silicate melt pockets in upper mantle xenoliths from the Bakony - Balaton Highland Volcanic Field, Western Hungary. Lithos 61, 79-102.

Bali E., Zajacs Z., Kovacs I., Szabó C., Halter W., Vaselli O., Torok K. and Bodnar R. J. (2008) A Quartz-bearing Orthopyroxene-rich Websterite Xenolith from the Pannonian Basin, Western Hungary : Evidence for Release of Quartz-saturated Melts from a Subducted Slab. J. Petrol. 49, 421-439.

Bali E., Zanetti A., Szabó C., Peate D. W. and Waight T. E. (2008) A micro-scale investigation of melt production and extraction in the upper mantle based on silicate melt pockets in ultramafic xenoliths from the Bakony-Balaton Highland Volcanic Field (Western Hungary). Contrib. to Mineral. Petrol. 155, 165-179. Available at: http://link.springer.com/10.1007/s00410-007-0234-4 [Accessed January 25, 2014]. 
Balogh K. and Németh K. (2005) Evidence for the Neogene small-volume intracontinental volcanism in Western Hungary: K/Ar geochronology of the Tihany Maar Volcanic Complex. Geol. Carpathica 56, 91-99.

Balogh K. and Pécskay Z. (2001) K/Ar and Ar/Ar geochronological studies in the PannonianCarpathians-Dinarides (PANCARDI) region. Acta Geol. Hung. 44, 281-299.

Ban M., Witt-Eickschen G., Klein M. and Seck H. a. (2005) The origin of glasses in hydrous mantle xenoliths from the West Eifel, Germany: Incongruent break down of amphibole. Contrib. to Mineral. Petrol. 148, 511-523.

Beccaluva L., Bondadiman C., Coltorti M., Salvini L. and Siena F. (2001) Depletion Events, Nature of Metasomatizing Agent and Timing of Enrichment Processes in Lithospheric Mantle Xenoliths from the Veneto Volcanic Province. J. Petrol. 42, 173-187.

Bodinier J. ., Vasseur G., Vernieres J. and Dupuy C. F. (1990) Mechanisms of mantle metasomatism: geochemical evidence from the Lherz orogenic peridotite. J. Petrol. 31, $597-628$.

Brey G. P., Kohler T. and Nickel K. G. (1990) Geothermobarometry in Four-phase Lherzolites I . Experimental Results from 10 to 60 kb. J. Petrol. 31, 1313-1352.

Castillo P. R., Janney P. E. and Solidum R. U. (1999) Petrology and geochemistry of Camiguin Island, southern Philippines: insights to the source of adakites and other lavas in a complex arc setting. Contrib. to Mineral. Petrol. 134, 33-51.

Coltorti M., Beccaluva L., Bonadiman C., Faccini B., Ntaflos T. and Siena F. (2004) Amphibole genesis via metasomatic reaction with clinopyroxene in mantle xenoliths from Victoria Land, Antarctica. Lithos 75, 115-139.

Coltorti M., Beccaluva L., Bonadiman C., Salvini L. and Siena F. (2000) Glasses in mantle xenoliths as geochemical indicators of metasomatic agents. Earth Planet. Sci. Lett. 183, 303-320. Available at: http://linkinghub.elsevier.com/retrieve/pii/S0012821X00002740. 
Coltorti M., Bonadiman C., Faccini B., Ntaflos T. and Siena F. (2007) Slab melt and intraplate metasomatism in Kapfenstein mantle xenoliths (Styrian Basin, Austria). Lithos 94, 66-89.

Coltorti M., Bonadiman C., Hinton R. W., Siena F. and Upton B. G. J. (1999) Carbonatite Metasomatism of the Oceanic Upper Mantle : Evidence from Clinopyroxenes and Glasses in Ultramafic Xenoliths of Grande Comore, Indian Ocean. J. Petrol. 40, 133165.

Creon L., Rouchon V., Youssef S., Rosenberg E., Delpech G., Guyot F., Szabó C., Tafforeau P., Boller E., Asimow P. D., Antoshechkina P. M. and Ghiorso M. S. Highly CO2supersaturated melts in the Pannonian lithospheric mantle - A transient carbon reservoir? this Vol.

Csontos L., Nagymarosy A., Horváth F. and Kovác M. (1992) Tertiary evolution of the IntraCarpathian area: a model. Teconophysics 208, 221-241.

Dawson J. (1984) Contrasting types of upper-mantle metasomatism? In: Kornprobst J (ed) Kimberlites II: The mantle and crust- mantle relationships. Holland, 289.

Defant M. J. and Kepezhinskas P. (2001) Evidence suggests slab melting in arc magmas. Eos, Trans. Am. Geophys. Union 83, 256.

Delpech G., Grégoire M., O’Reilly S. Y., Cottin J. Y., Moine B., Michon G. and Giret a. (2004) Feldspar from carbonate-rich silicate metasomatism in the shallow oceanic mantle under Kerguelen Islands (South Indian Ocean). Lithos 75, 209-237.

Demény A., Dallai L., Frezzotti M.-L., Vennemann T. W., Embey-Isztin A., Dobosi G. and Nagy G. (2010) Origin of CO2 and carbonate veins in mantle-derived xenoliths in the Pannonian Basin. Lithos 117, 172-182. Available at: http://linkinghub.elsevier.com/retrieve/pii/S0024493710000575 [Accessed December 7, 2012]. 
872 Demény A., Vennemann T. ., Hegner E., Nagy G., Milton J. ., Embey-Isztin A., Homonnay Z.

873

874

875

876

877

878

879

880

881

882

883

884

885

886

887

888

889

890

891

892

893

894

895

896 and Dobosi G. (2004) Trace element and C-O-Sr-Nd isotope evidence for subductionrelated carbonate-silicate melts in mantle xenoliths (Pannonian Basin, Hungary). Lithos 75, 89-113. Available at: http://www.sciencedirect.com/science/article/pii/S0024493704000209 [Accessed March $16,2015]$.

Demény A., Vennemann T. W., Homonnay Z. and Milton A. (2005) Origin of amphibole megacrysts in the Pliocene-Pleistocene basalts of the Carpathian-Pannonian region. Geol. Carpathica 56, 179-189.

Downes H., Embey-Isztin A. and Thirlwall M. F. F. . (1992) Petrology and geochemistry of spinel peridotite xenoliths from the western Pannonian Basin (Hungary): evidence for an association between enrichment and texture in the upper mantle. Contrib. Mineral. Petrol. 109, 340-354.

Draper D. S. and Green T. H. (1997) P - T Phase Relations of Silicic, Alkaline, Aluminous Mantle-Xenolith Glasses Under Anhydrous and C - O - H Fluid-saturated Conditions. $J$. Petrol. 38, 1187-1224.

Embey-Isztin a, Dobosi G., Altherr R. and Meyer H.-P. (2001) Thermal evolution of the lithosphere beneath the western Pannonian Basin: evidence from deep-seated xenoliths. Tectonophysics 331, 285-306. Available at: http://linkinghub.elsevier.com/retrieve/pii/S0040195100002870.

Embey-Isztin A., Dobosi G., Bodinier J.-L., Bosch D., Jenner G. a., Pourtales S. and Bruguier O. (2014) Origin and significance of poikilitic and mosaic peridotite xenoliths in the western Pannonian Basin: geochemical and petrological evidences. Contrib. to Mineral. Petrol. 168, 1054. Available at: http://link.springer.com/10.1007/s00410-014-1054-y. 
compilation of new major, trace element and isotope geochemical analyses of the young alkali basalts from the Pannonian Basin. Fragm. Mineral. Palaeontol. 16, 5-26.

Embey-isztin A., Downes H., James D. E. E., Upton B. G. J. G. J., Dobosi G., Ingram G. A. a., Harmon R. S. S. and Scharbert H. G. G. (1993) The petrogenesis of Pliocene alkaline volcanic rocks from the Pannonian Basin, Eastern central Europe. J. Petrol. 34, 317-343.

902 Embey-Isztin A. and Scharbert H. G. (2001) Glasses in peridotite xenoliths from the western 903 Pannonian Basin. Per. Mineral. 70, 359-376.

904 Embey-Isztin A., Scharbert H. G., Dietrich H. and Poultidis H. (1989) Petrology and geochemistry of peridotite xenoliths in alkali basalts from the Transdanubian volcanic region. J. Petrol. 30, 79-106.

Falus G., Drury M. R., van Roermund H. L. M. and Szabó C. (2004) Magmatism-related localized deformation in the mantle: a case study. Contrib. to Mineral. Petrol. 146, 493505. Available at: http://link.springer.com/10.1007/s00410-003-0513-7 [Accessed February 8, 2014].

Falus G., Szabó C., Kovács I., Zajacz Z. and Halter W. (2007) Symplectite in spinel lherzolite xenoliths from the Little Hungarian Plain, Western Hungary: A key for understanding the complex history of the upper mantle of the Pannonian Basin. Lithos 94, 230-247. Available at: http://linkinghub.elsevier.com/retrieve/pii/S0024493706001848 [Accessed elements and an assessment of the influence of rutile on the trace element characteristics 

of subduction zone magmas. Geochim. Cosmochim. Acta 64, 933-938.

923 Gagnon J. E., Fryer B. J., Samson I. M. and Williams-Jones A. E. (2008) Quantitative 924 analysis of silicate certified reference materials by LA-ICPMS with and without an internal standard. J. Anal. At. Spectrom. 23, 1529.

Ghiorso M. S. and Gualda G. A. R. (2015) An H2O-CO2 mixed fluid saturation model

Gualda G. A. R., Ghiorso M. S., Lemons R. V. and Carley T. L. (2012) Rhyolite-MELTS: a Modified Calibration of MELTS Optimized for Silica-rich, Fluid-bearing Magmatic

Hellebrand E., Snow J. E., Hoppe P. and Hofmann A. W. (2002) Garnet-field Melting and Late-stage Refertilization in " Residual " Abyssal Peridotites from the Central Indian Ridge. J. Petrol. 43, 2305-2338.

Horvath F. (1993) Towards a mechanical model for the formation of the Pannonian Basin. Tectonophysics 226, 333-357.

Huismans R. S., Podladchikov Y. Y. and Cloetingh S. a. P. L. (2002) The Pannonian basin: Dynamic modelling of the transition from passive to active rifting. In EGU Special

Ionov D. a., Chanefo I. and Bodinier J. L. (2005) Origin of Fe-rich lherzolites and wehrlites from Tok, SE Siberia by reactive melt percolation in refractory mantle peridotites. 
Johnson K. T. M., Dick H. J. B. and Shimizu N. (1990) Melting in the oceanic upper mantle: An ion microprobe study of diopsides in abyssal peridotites. J. Geophys. Res. 95, 2661.

Kazmer M. and Kovacs S. (1985) ermian-Paleogene paleogeography along the Eastern part of the Insubric-Periadriatic Lineament system: evidence for continental escape of the Bakony- Drauzug unit. Acta Geol. Hung. 1-2, 71-84.

Kereszturi G., Németh K., Csillag G., Balogh K. and Kovács J. (2011) The role of external environmental factors in changing eruption styles of monogenetic volcanoes in a Mio/Pleistocene continental volcanic field in western Hungary. J. Volcanol. Geotherm. Res. 201, 227-240. Available at: http://www.sciencedirect.com/science/article/pii/S0377027310002647 [Accessed January 19, 2015].

Kovacs I., Falus G., Stuart G., Hidas K., Szabó C., Flower M. F. J., Hegedűs E., Posgay K. and Zilahi-Sebess L. (2012) Seismic anisotropy and deformation patterns in upper mantle xenoliths from the central Carpathian-Pannonian region: Asthenospheric flow as a driving force for Cenozoic extension and extrusion? Tectonophysics 514-517, 168-179. Available at: http://linkinghub.elsevier.com/retrieve/pii/S0040195111004562 [Accessed November 14, 2014].

Laurora a, Mazzucchelli M., Rivalenti G., Vannucci R., Zanetti A., Barbieri M. a and Cingolani C. a (2001) Metasomatism and melting in carbonated peridotite xenoliths from the mantle wedge: The Gobernador Gregores case (southern Patagonia). J. Petrol. 42, 69-87.

Locock A. J. (2014) An Excel spreadsheet to classify chemical analyses of amphiboles following the IMA 2012 recommendations. Comput. Geosci. 62, 1-11. Available at: http://dx.doi.org/10.1016/j.cageo.2013.09.011.

Lu J., Zheng J., Grif W. L., Reilly S. Y. O. and Pearson N. J. (2015) Lithos Microscale effects 

of melt in filtration into the lithospheric mantle : Peridotite xenoliths from Xilong, South China. Lithos 232, 111-123.

974 Martin U., Auer A., Németh K. and Breitkreuz C. (2003) Mio-pliocene phreatomagmatic volcanism in a Fluvio-Lacustrine basin in Western Hungary. GeoLines 15, 93-97.

McDonough W. F. F. and Sun S. -s. S. . (1995) The composition of the Earth. Chem. Geol. 120, 223-253. Available at: http://www.sciencedirect.com/science/article/pii/0009254194001404 [Accessed January $15,2015]$.

Mercier J. C. and Nicolas A. (1975) Textures and Fabrics of Upper-Mantle Peridotites as Illustrated by Xenoliths from Basalts. J. Petrol. 16.

Miller C., Zanetti a., Thöni M., Konzett J. and Klötzli U. (2012) Mafic and silica-rich glasses in mantle xenoliths from Wau-en-Namus, Libya: Textural and geochemical evidence for peridotite-melt reactions. Lithos 128-131, 11-26. Available at: http://dx.doi.org/10.1016/j.lithos.2011.11.004.

Moine B. N., Grégoire M., O’Reilly S. Y., Delpech G., Sheppard S. M. F., Lorand J. P., Renac C., Giret a. and Cottin J. Y. (2004) Carbonatite melt in oceanic upper mantle beneath the Kerguelen Archipelago. Lithos 75, 239-252.

Neumann E.-R., Wulff-Pedersen E., Pearson N. J. and Spenser E. a (2002) Mantle xenoliths from Tenerife (Canary Islands): evidence for reactions between mantle peridotites and silicic carbonatite melts inducing Ca metasomatism. J. Petrol. 43, 825-857. Available at: http://petrology.oupjournals.org/cgi/content/abstract/43/5/825.

Niida K. and Green D. H. (1999) Stability and chemical composition of pargasitic amphibole in MORB pyrolite under upper mantle conditions. Contrib. to Mineral. Petrol. 135, 1840.

Olafsson M. and Eggler D. H. (1983) Phase relations of amphibole, amphibole-carbonate, and 
phlogopite-carbonate peridotite: petrologic constraints on the asthenosphere. Earth Planet. Sci. Lett. 64, 305-315. Available at: http://linkinghub.elsevier.com/retrieve/pii/0012821X83902121.

Posgay K., Bodoky T., Hegedus E., Kovacsvolgyi S., Lenkey L., Szafian P., Takacs E., T1mar Z. and Varga G. (1995) Asthenospheric structure beneath a Neogene basin in southeast Hungary. Tectonophysics 252, 467-484.

1004

Putirka K. D. (2008) Thermometers and Barometers for Volcanic Systems. Mineral.

\section{5}

1006

1007

1008

1009

1010

1011

1012

1013

1014

1015

1016

Szabó C., Bodnar R. J. and Sobolev A. V. (1996) Metasomatism associated with subductionrelated, volatile-rich silicate melt in the upper mantle beneath the Nograd-Gomor Volcanic Field, Northern HungarySouthern Slovakia - Evidence from silicat. Eur. J. 
1022

1023

1024

1025

1026

1027

1028

1029

1030

1031

1032

1033

1034

1035

1036

1037

1038

1039

1040

1041

1042

1043

1044

1045

1046

Miner. 8, 881-899.

Szabó C., Falus G., Zajacz Z., Kovács I. and Bali E. (2004) Composition and evolution of lithosphere beneath the Carpathian-Pannonian Region: a review. Tectonophysics 393, 119-137. Available at: http://linkinghub.elsevier.com/retrieve/pii/S0040195104002574 [Accessed December 7, 2012].

Szabó C., Harangi S. and Csontos L. (1992) Review of Neogene and Quaternary volcanism of the Carpathian-Pannonian region. Tectonophysics 208, 243-256.

Szabó C., Harangi S., Vaselli O. and Downes H. (1995) Temperature and oxygen fugacity in peridotite xenoliths from the Carpathian-Pannonian Region. ACta Vulcanol. 7, 231-239.

Szabó C., Hidas K., Bali E., Zajacz Z., Kovács I., Yang K., Guzmics T. and Török K. (2009) Melt-wall rock interaction in the mantle shown by silicate melt inclusions in peridotite xenoliths from the central Pannonian Basin (western Hungary). Isl. Arc 18, 375-400. Available at: http://doi.wiley.com/10.1111/j.1440-1738.2009.00672.x [Accessed December 7, 2012].

Szabó C., Kovacs I., Dégi J., Kothay K., Torok K., Hidas K. K., Konya P., Berkesi M., Degi J., Kothay K., Torok K., Hidas K. K., Konya P. and Berkesi M. (2010) From maars to lava lakes: Ultramafic and granulite xenoliths associated with the alkaline basaltic volcanism of the Pannonian Basin. In Mineralogica-petrographica field guide series pp.

Tašárová A., Afonso J. C., Bielik M., Götze H.-J. and Hók J. (2009) The lithospheric structure of the Western Carpathian-Pannonian Basin region based on the CELEBRATION 2000 seismic experiment and gravity modelling. Tectonophysics 475, 454-469. Available at: http://linkinghub.elsevier.com/retrieve/pii/S0040195109003229 [Accessed January 22, 2014].

Török K., Dégi J., Szép A. and Marosi G. (2005) Reduced carbonic fluids in mafic granulite 
xenoliths from the Bakony-Balaton Highland Volcanic Field, W-Hungary. Chem. Geol. 223, 93-108. Available at: http://linkinghub.elsevier.com/retrieve/pii/S0009254105002913 [Accessed December 7, 2012].

Vannucci R., Bottazzi P., Wulff-Pedersen E. and Neumann E.-R. (1998) Partitioning of REE, Y, Sr, Zr, and Ti between clinopyroxene and silicate melts in the mantle under La Palma (Canary Islands): implications for the nature of the metasomatic agents. Earth Planet. Sci. Lett. 158, 39-51.

Wijbrans J., Németh K., Martin U. and Balogh K. (2007) 40Ar/39Ar geochronology of Neogene phreatomagmatic volcanism in the western Pannonian Basin, Hungary. $J$. Volcanol. Geotherm. Res. 164, 193-204. Available at: http://www.sciencedirect.com/science/article/pii/S0377027307001357 [Accessed January 14, 2015].

Wulff-Pedersen E., Neumann E.-R., Vannucci R., Bottazzi P. and Ottolini L. (1999) Silicic melts produced by reaction between peridotite and infiltrating basaltic melts : ion probe data on glasses and minerals in veined xenoliths from La Palma, Canary Islands. Contrib. to Mineral. Petrol. 137, 59-82.

Xiong X. L., Adam J. and Green T. H. (2005) Rutile stability and rutile/melt HFSE partitioning during partial melting of hydrous basalt: Implications for TTG genesis. Chem. Geol. 218, 339-359.

Yaxley G. M. and Kamenetsky V. (1999) In situ origin for glass in mantle xenoliths from southeastern Australia : insights from trace element compositions of glasses and metasomatic phases. Earth Planet. Sci. Lett. 172, 97-109. Available at: http://dx.doi.org/10.1016/S0012-821X(99)00196-X. 
$1 \quad$ Figure captions

2

3 Figure 1: Location of the Bakony Balaton highland volcanic fied and of the four sampling

4 areas (Szentbékkálla, Szigliget, Füzes-tó, Mindszentkálla). The light grey is area is the Outer

5 Carpathians and the dark grey area represents the Carpathian belt (North, East and South-

6 East), Eastern Alps (West) and Dinarides (South West).

7

Figure 2: Streckeisen diagram (Streckeisen, 1976) of studied mantle xenoliths. They are all within the fields of lherzolites (diamonds) and harzburgites (triangles). Small circles are literature data from Downes et al. (1992); Falus et al. (2004); Bali et al. (2002). SZBSzentbékkálla, SZG- Szigliget, FT- Füzes-tó and MSZK- Mindszentkálla. The grey area corresponds to the Sub-continental lithospherique mantle (Downes et al., 1992).

Figure 3: Textural characteristics of the Szentbékkálla, Szigliget, Füzes-tó and Mindszentkálla mantle xenoliths. A- Primary silicate melt inclusions (SMI) in a primary cpx; Some cpx present spongy rim (SZG14). B- Poikilitic opx containing ol and trails of secondary fluid inclusions (SZG14). C- Melt vein crosscutting the peridotite sample and reacting with Cpx (spongy textures); secondary crystallization of SpII, OlII and CpxII in the melt; trails of secondary fluid inclusions are crosscutting the vein (SZB16). D- Interconnected melt pockets in SZG23; The box is a zoom in a melt pocket of SZB16. E- Glass pocket with few cpx secondary crystallization at boundaries (SZG44). F- Numerous trails of secondary fluid inclusions crosscutting together cpx and opx (SZB51); The box is a zoom on fluid inclusions. G-. Pseudomorphic melt pocket after amphibole breakdown (SZB51). H- Pseudomorphic melt pocket after amphibole breakdown (FT08P. Ol- olivine, Opx- Orthopyroxene, Cpx- 
Clinopyroxene, Sp- spinel, Amp- amphibole, FI- fluid inclusions, MP- melt pocket, Vsvesicle, M.I- Primary mineral, M.II- Secondary mineral, SMI- silicate melt inclusion.

Figure 4: Major-element compositions for primary minerals of the mantle xenoliths from the four sampled areas. Literature from Downes et al. (1992); Embey-Isztin et al. (1989); Bali et al. (2002); Falus et al. (2004); Demény et al. (2004, 2005). Blue squares: primitive mantle, triangles: harzburgite-like, diamonds: lherzolites. Black, dark-grey, light grey and white colors are respectively assigned to Szentbékkálla, Szigliget, Füzes-tó and Mindszentkálla. PM - partial melting.

Figure 5: Major element compositions of the newly formed cpx, ol and spinels. The grey area shows the domain for primary mineral compositions for comparison. Black circles: Szentbékkálla, dark-grey circles: Szigliget, light-grey circles: Füzes-tó. Smaller dots are from Bali et al. (2002).

Figure 6: REE and trace-element patterns for primary clinopyroxene and amphibole from the four localities. Grey areas are literature data from Embey-Isztin et al. (2014). Black, darkgrey, light grey and black dashed lines are respectively assigned to Szentbékkálla, Szigliget, Füzes-tó and Mindszentkálla samples. See text for group description.

Figure 7: Major-element compositions for vein (circles) and melt pocket (diamond) glass in samples from SZB (black), SZG (dark-grey) and FT (light grey). The small grey circles are from Bali et al. (2002). Doted lines are assimilation of cpx (black), amp (dark grey) and sp (light grey). The dashed lines represent crystal fractionation (CF) trends calculated using 
Rhyolite-MELTS (Gualda et al., 2012; Ghiorso and Gualda, 2015). Black and grey square present respectively the starting compositions for crystal fractionation and assimilation.

Figure 8: Trace-element patterns for glass in melt pockets (SMP) in samples of SZB (dark), SZG (dark-grey) and FT (light-grey).

Figure 9: Textural observations of amphibole breakdown for the FT08P xenoliths. Vs vesicle, Gl - glass, Amp - amphibole, Cpx - clinopyroxene, Sp - spinel.

Figure 10: Trace element patterns illustrating the assimilation of amphibole in melt. Each doted line corresponds to the addition of $10 \%$ amphibole in initial vein type melt.

Figure 11: Pressure comparison between primary mineral chemical equilibrium, secondary crystalized mineral/melt chemical equilibrium, fluid inclusions trapping and vesicles last equilibrium with melt. Primary minerals are formed at deeper pressures and vesicles, silicate melt pockets and fluid inclusions trapping happened at close pressures near to the MOHO.

Figure 12: Major element variations in veins and melt pockets (MP) for Szentbékkálla (SZB), Szigliget (SZG) and Füzes-tó (FT). Comparison is given by adakites, mantle xenolith glasses from Draper \& Green (1997), experimental melts from Rapp et al. (1999), calc-alkali magmas of the Pannonian Basin (Harangi and Lenkey, 2007), silicate melt pockets of SZB mantle xenoliths (small circles, Bali et al., 2002; Demény et al., 2004) and silicate melt inclusions of SZG mantle xenoliths (small circles, Szabó et al., 2009). 
73 Figure 13: Trace element patterns comparison between glasses in veins from mantle xenoliths 74 and Northern Panonnian Basalts, calc-alkaline (16.5-2 Ma, Harangi and Lenkey, 2007) and

Figure 14: Glass from melt veins compared with known adakite compositional domains (Grey areas). Small dots are data from Bali et al. (2008).

Figure 15: Phase equilibrium diagram. A- Modified from Stern (2002) and Martin (1999). The blue field represents the assumed P-T source of the Si-rich melts in veins. lhz- lherzolite; gargarnet; amph- amphibole; sp- spinel; plg- plagioclase. The dry peridotite solidus is from Gudfinnsson \& Presnall (2005). B- Pressure-temperature diagram showing the effects of $\mathrm{CO}_{2}$ on the solidus of carbonated lithologies in the mantle. Two different estimates of the peridotite- $-\mathrm{CO}_{2}$ solidus are reported: $\mathrm{CMAS}-\mathrm{CO}_{2}$ after Dalton \& Presnall (1998) and Gudfinnsson \& Presnall (2005), and peridotite- $\mathrm{CO}_{2}$ (2.5 wt.\%) from Dasgupta \& Hirschmann (2006). The dry peridotite solidus in the CMAS system is from Gudfinnsson \& Presnall (2005). Eclogite- $\mathrm{CO}_{2}$ solidus (dry eclogite+5 wt.\% $\mathrm{CO}_{2}$ ) from Dasgupta et al. (2004). Asterisks (*) correspond to the $\mathrm{KNCFMASH}-\mathrm{CO}_{2}$ solidus (carbonated pelite+1.1 wt.\% $\mathrm{H}_{2} \mathrm{O}+4.8$ wt.\% $\mathrm{CO}_{2}$ ) from Thomsen \& Schmidt (2008). The effect of carbonates on the composition of melts generated at increasing temperature is reported as wt. $\% \mathrm{CO}_{2}$, based on the CMAS- $\mathrm{CO}_{2}$ system. The solid blue line represents the geotherm from Kovacs et al. (2012) Supp_data, Fig. a: Trace element modeling of residual clinopyroxene using the non-modal partial melting equations and parameters of Hellebrand et al. (2002) and CI-chondrite 
98 normalization values after McDonough \& Sun (1995). The numbers refer to the amount of

99 melting in percentage. Triangles are harzburgite-like rocks and diamonds are lherzolites-like 100 rocks.

101 


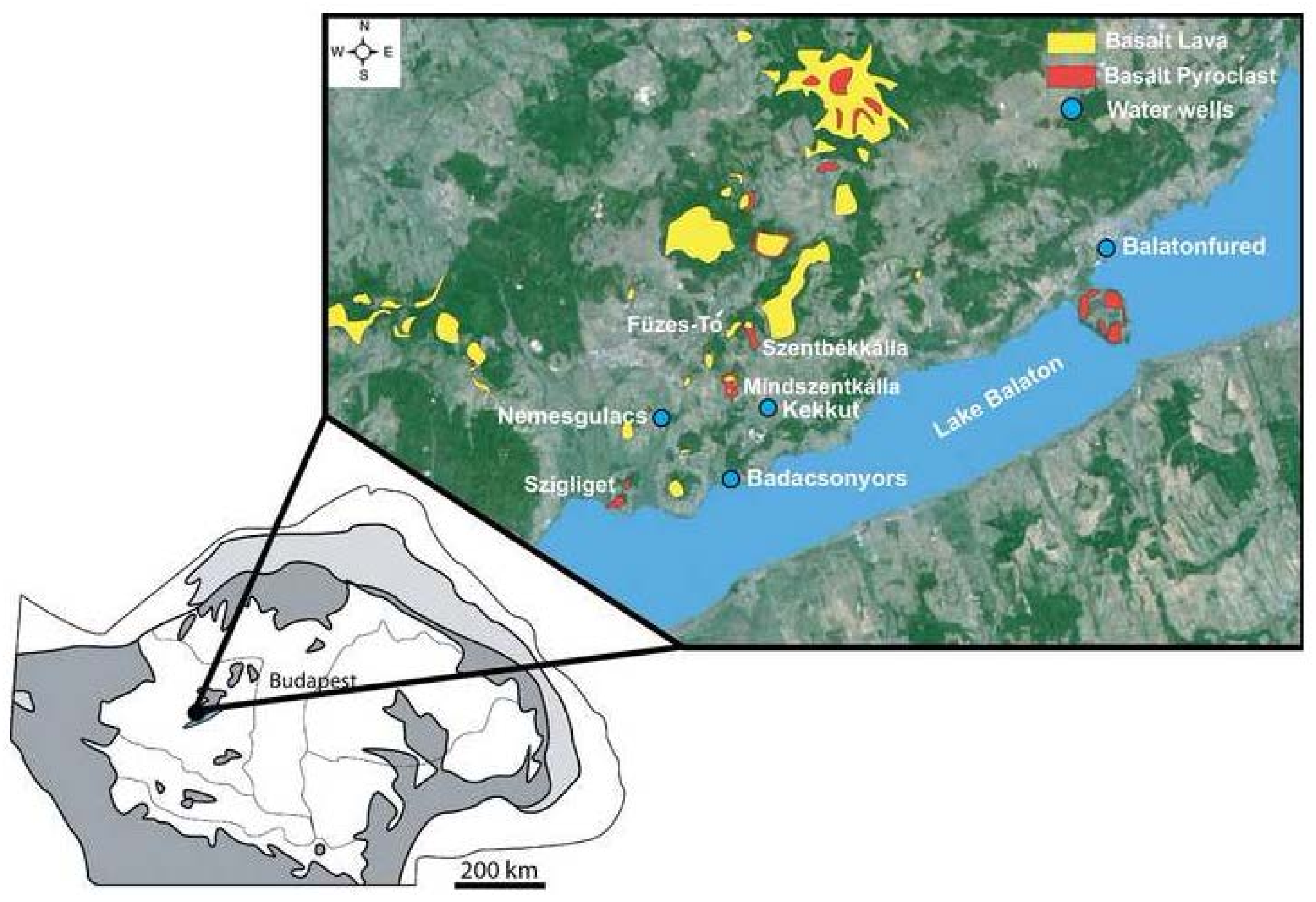




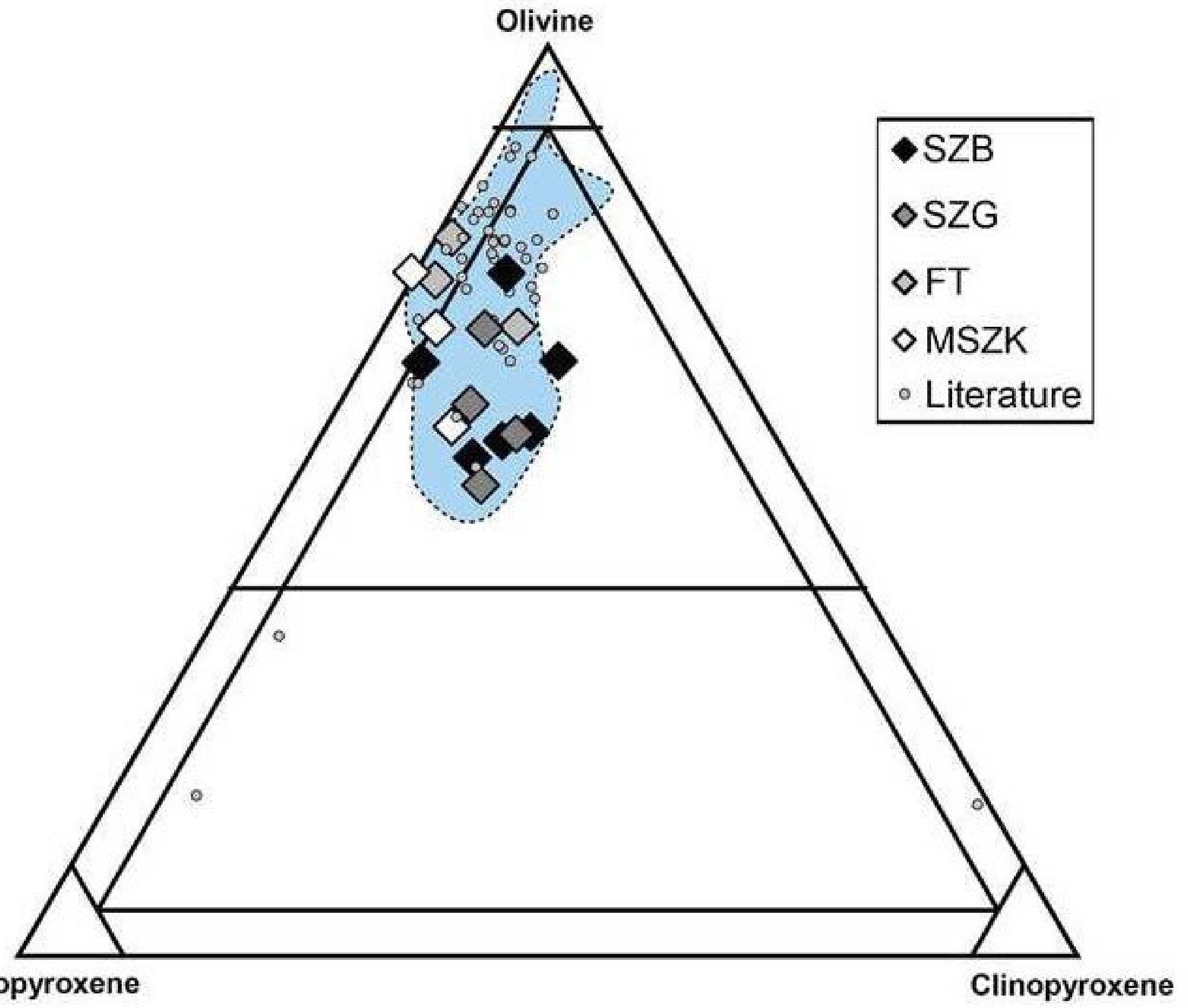




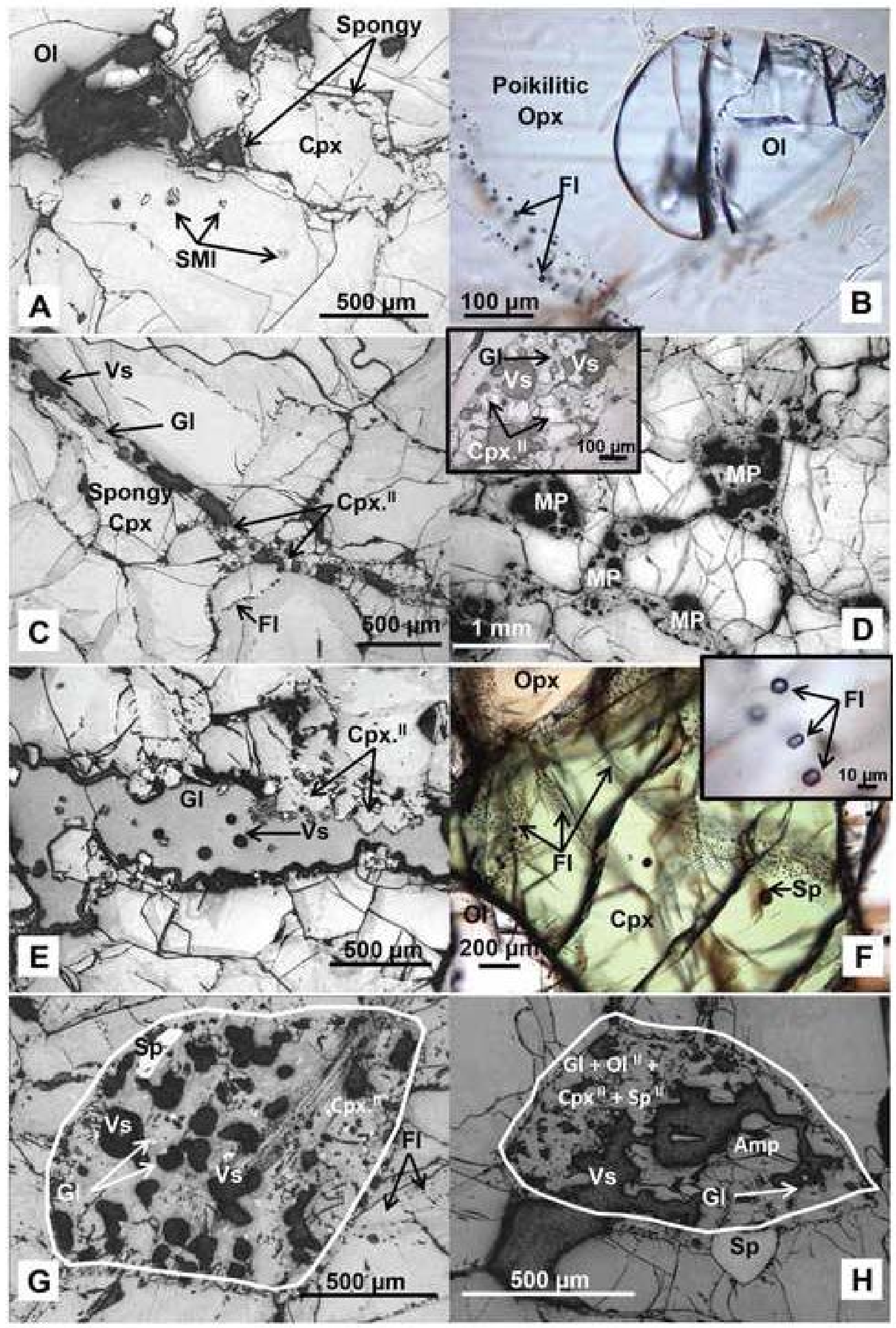




\section{Figure 4}

Click here to download high resolution image
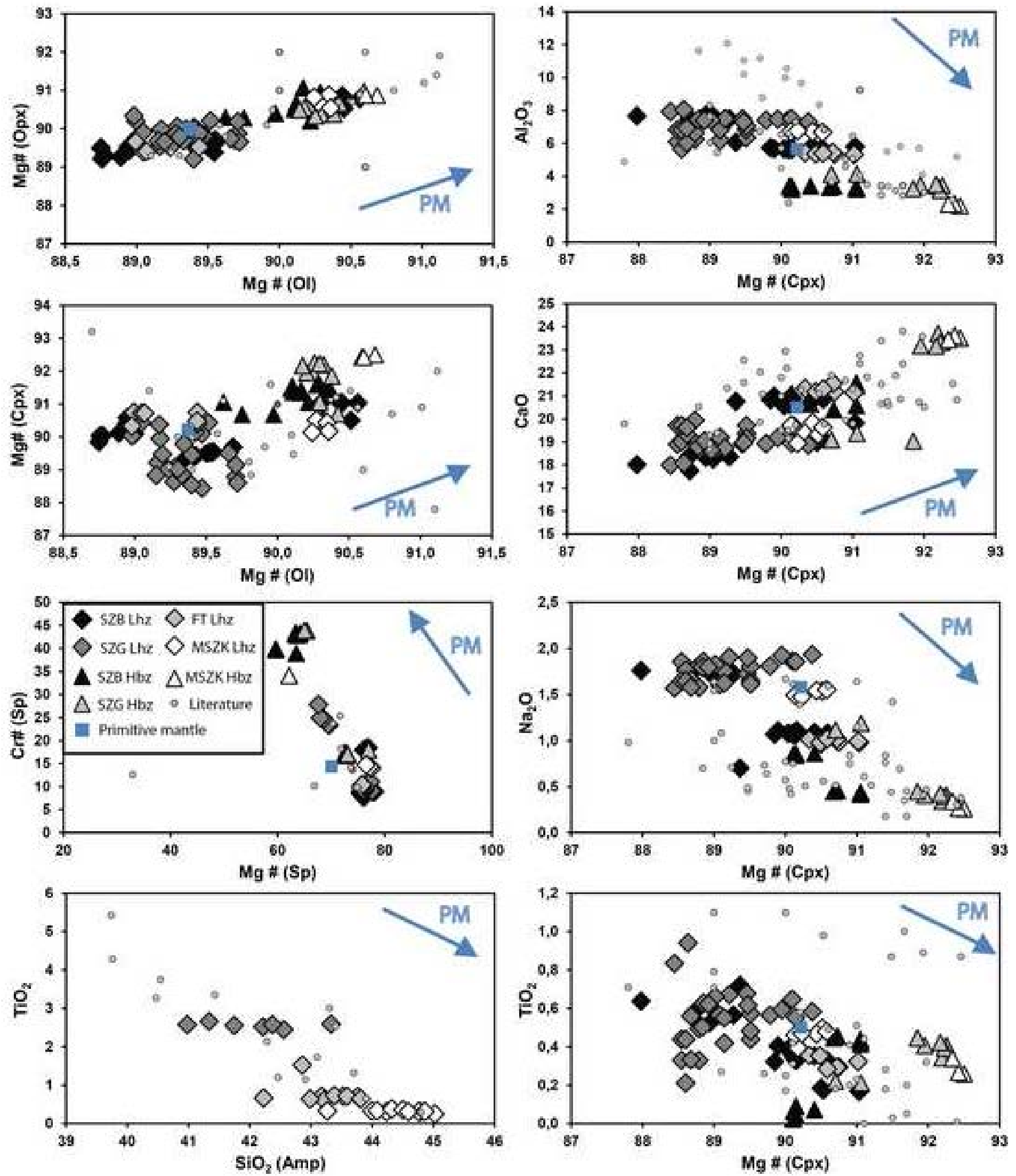

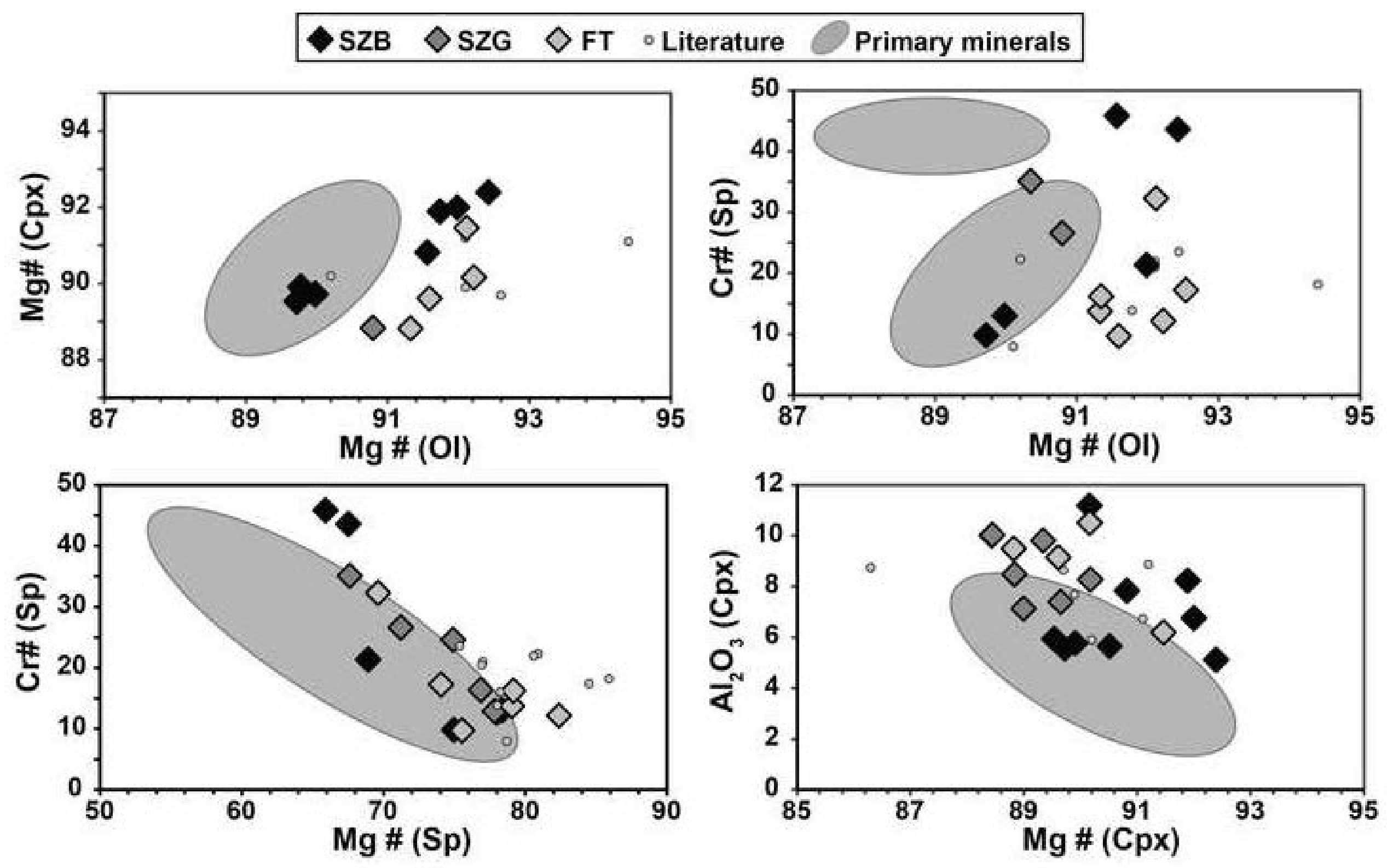


\section{Figure 6}

Click here to download high resolution image

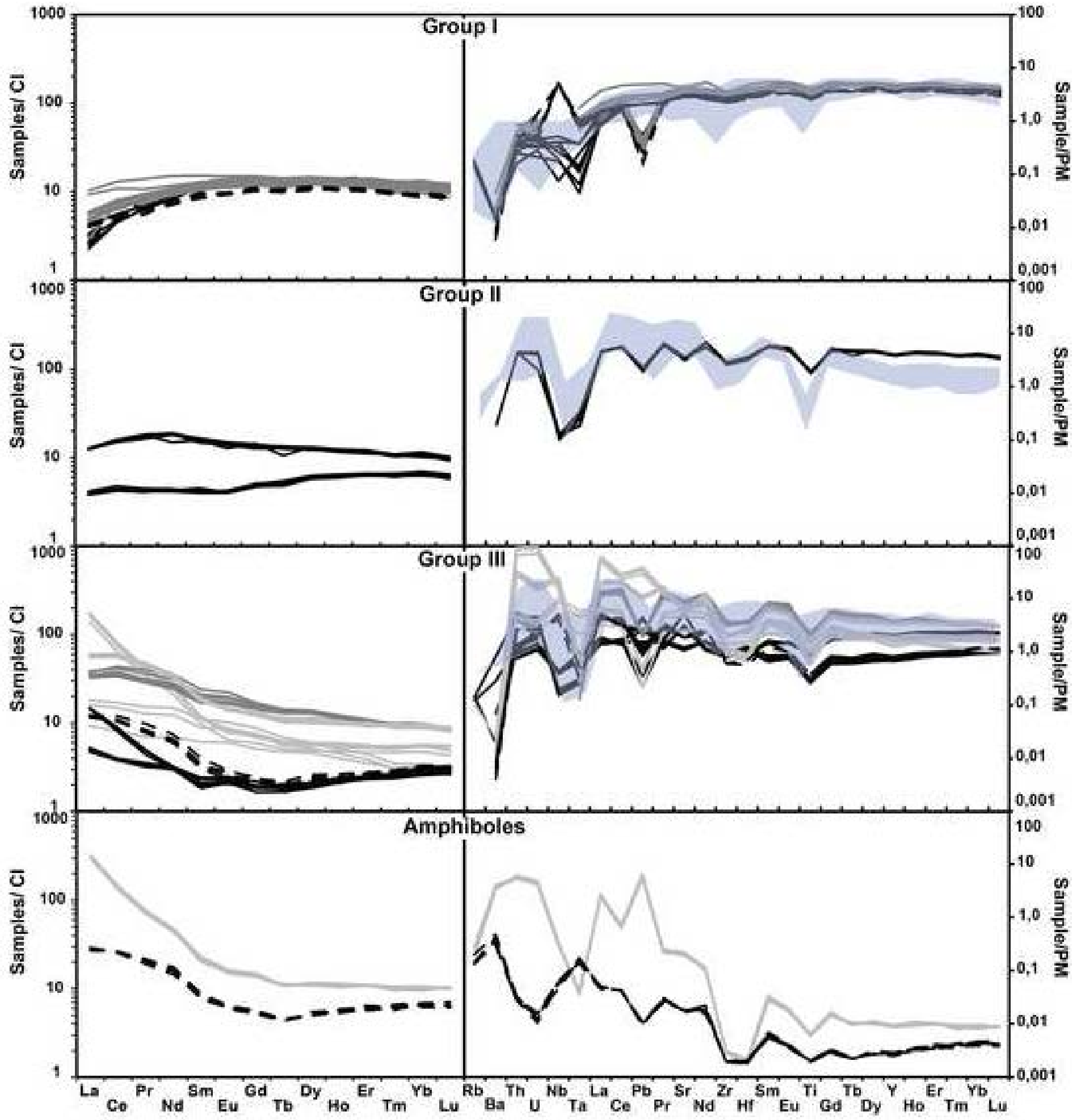




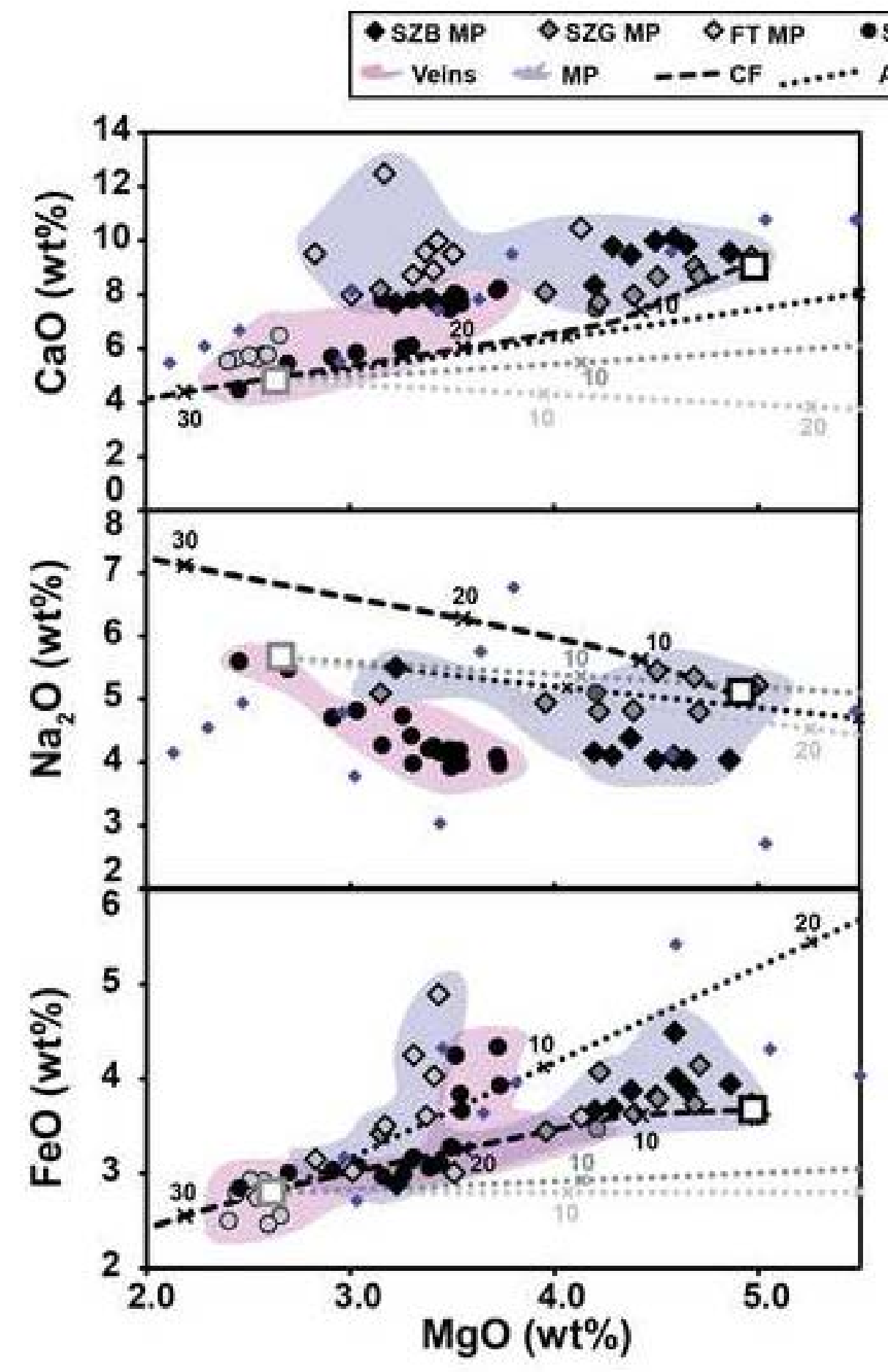

SZB vein OSZG SMI OFT vein * Literature
Assim Cpx $\ldots . . .+$ Assim Amp Assim Sp

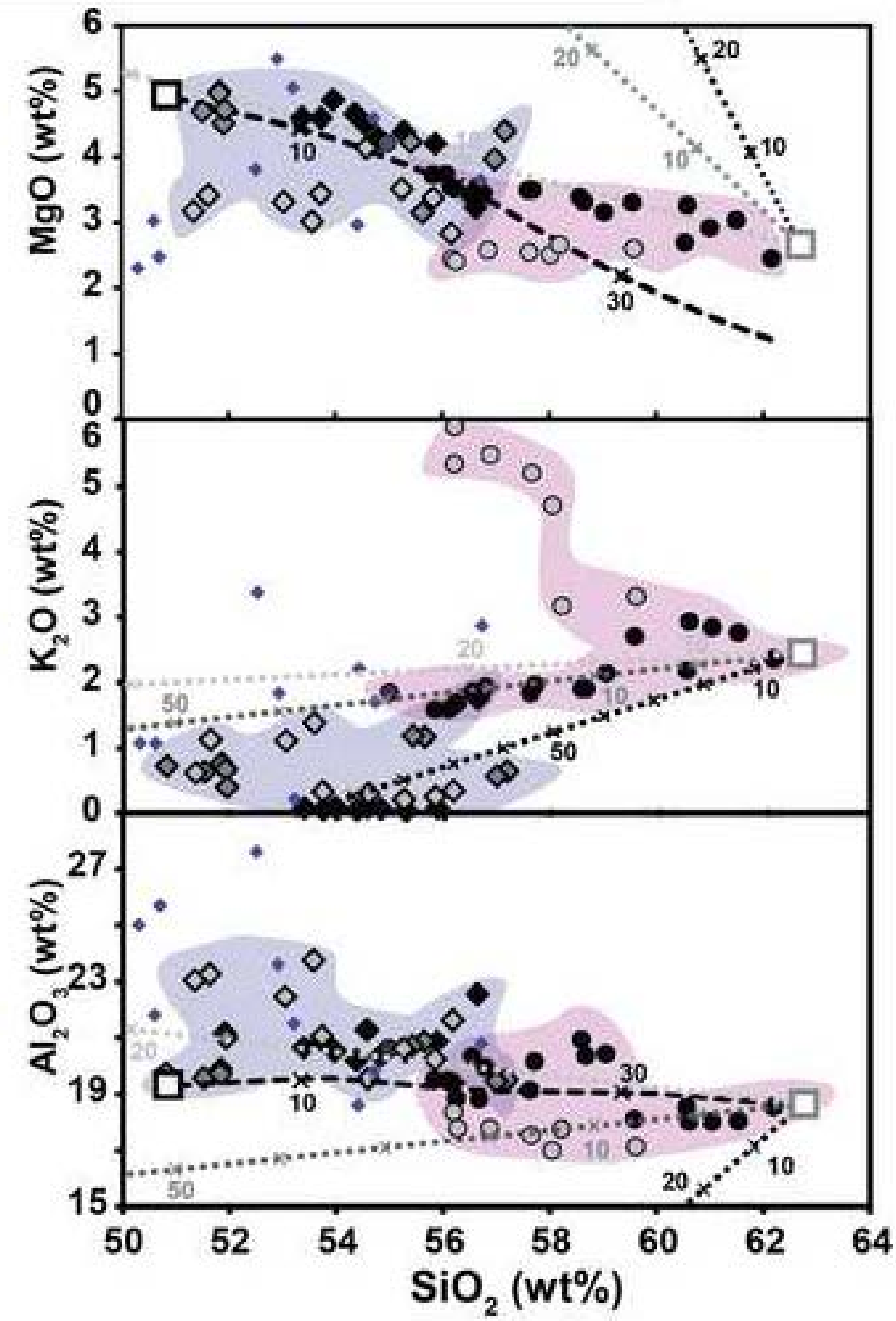




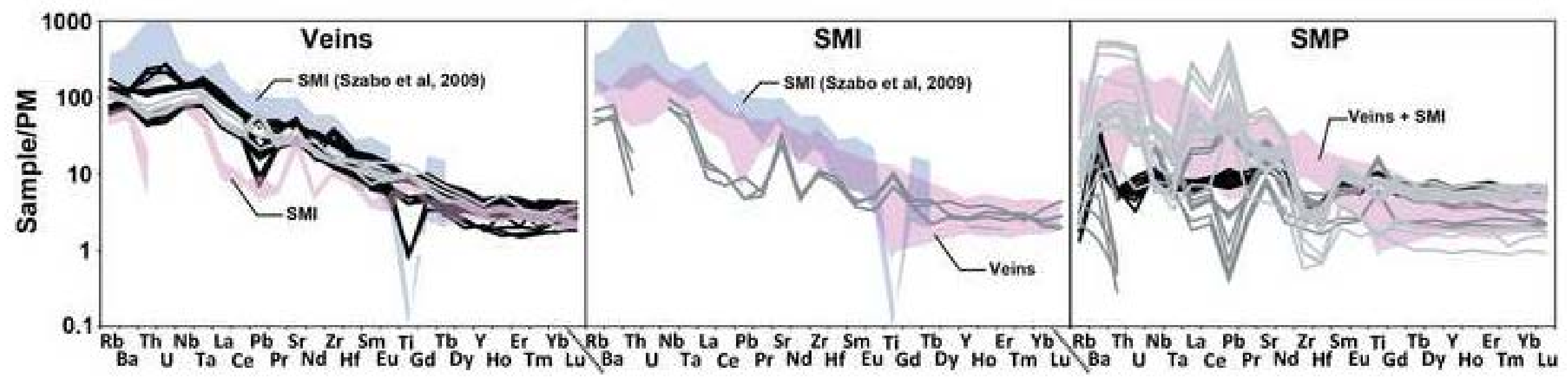


Click here to download high resolution image

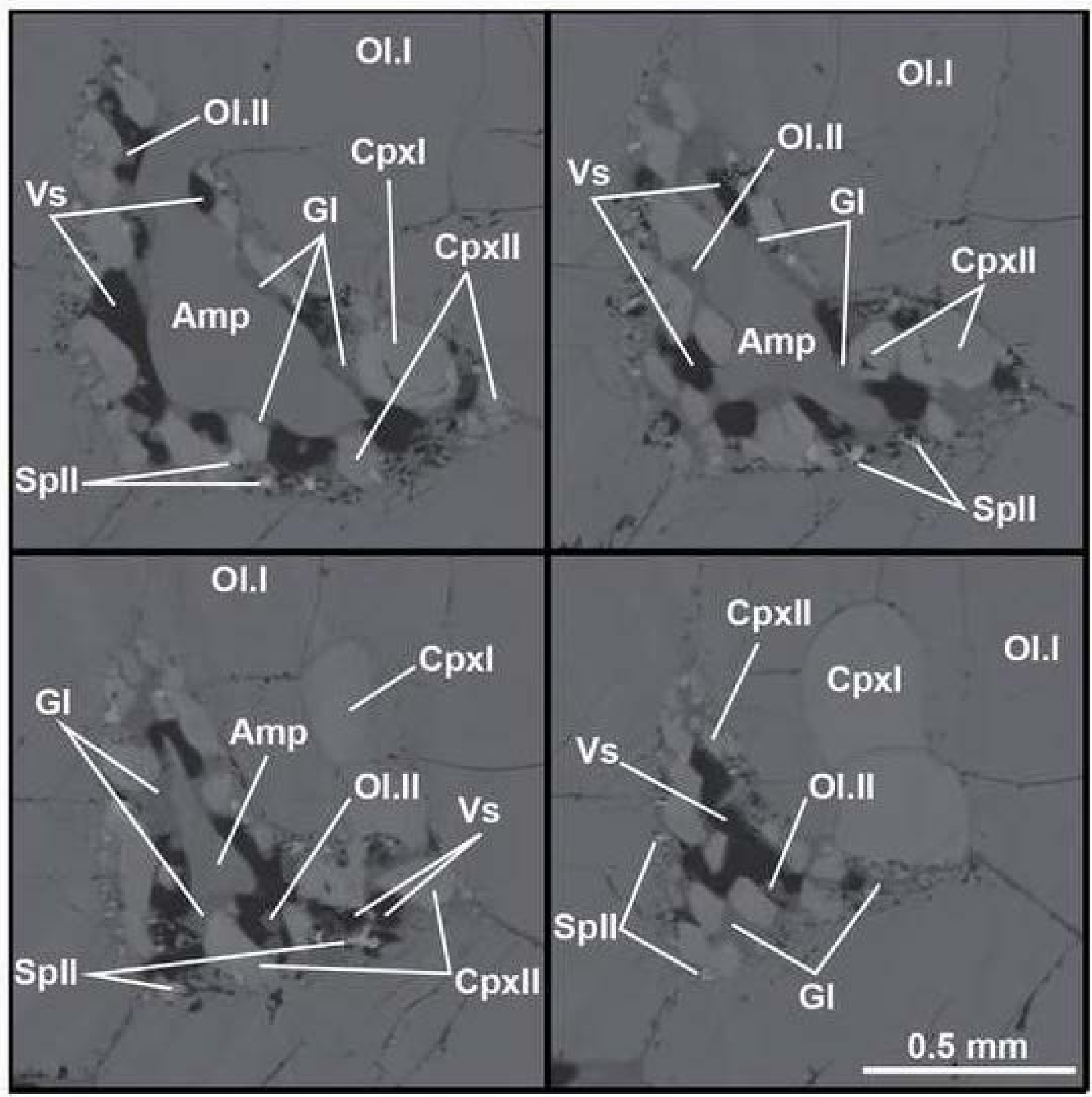



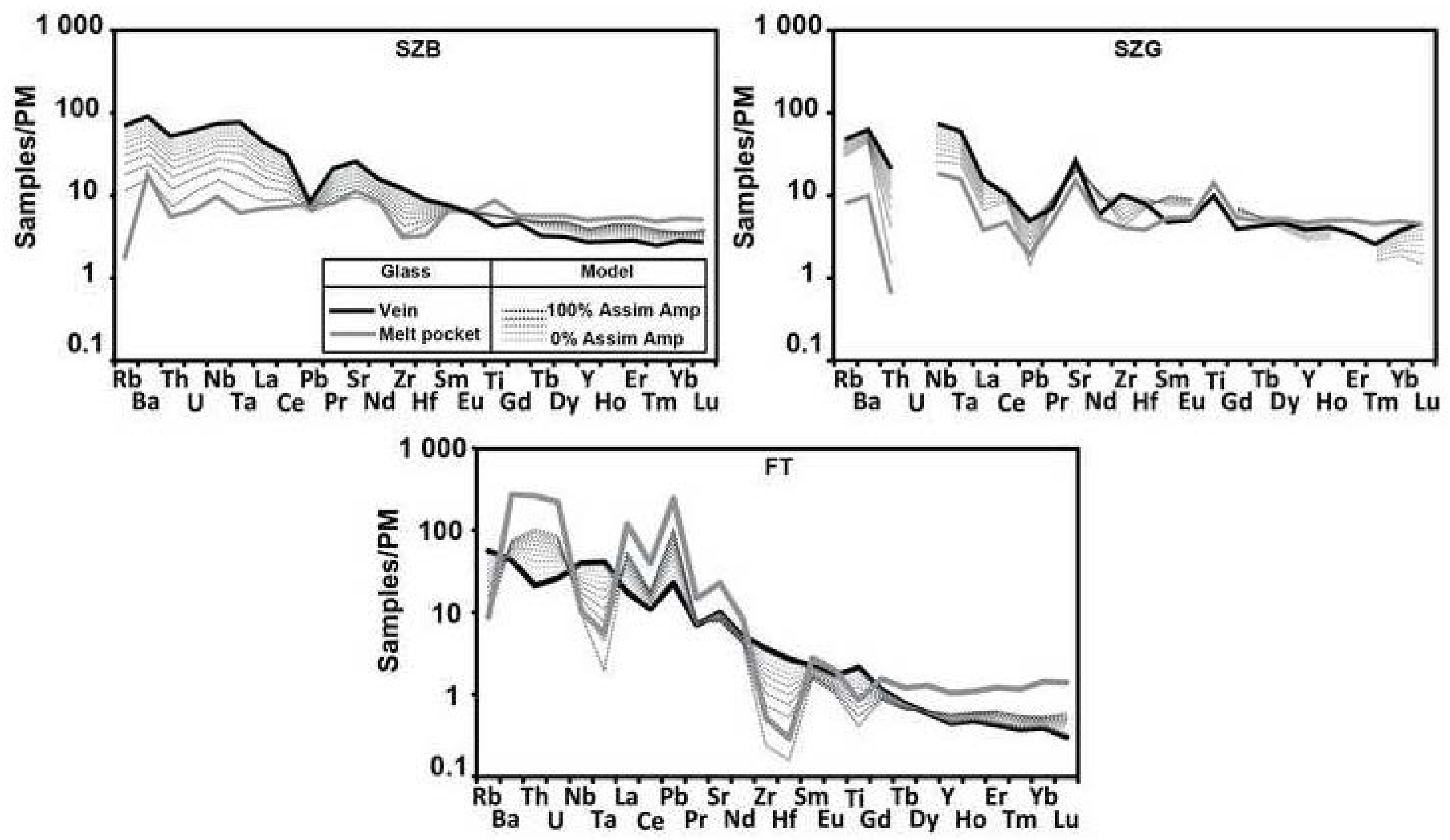


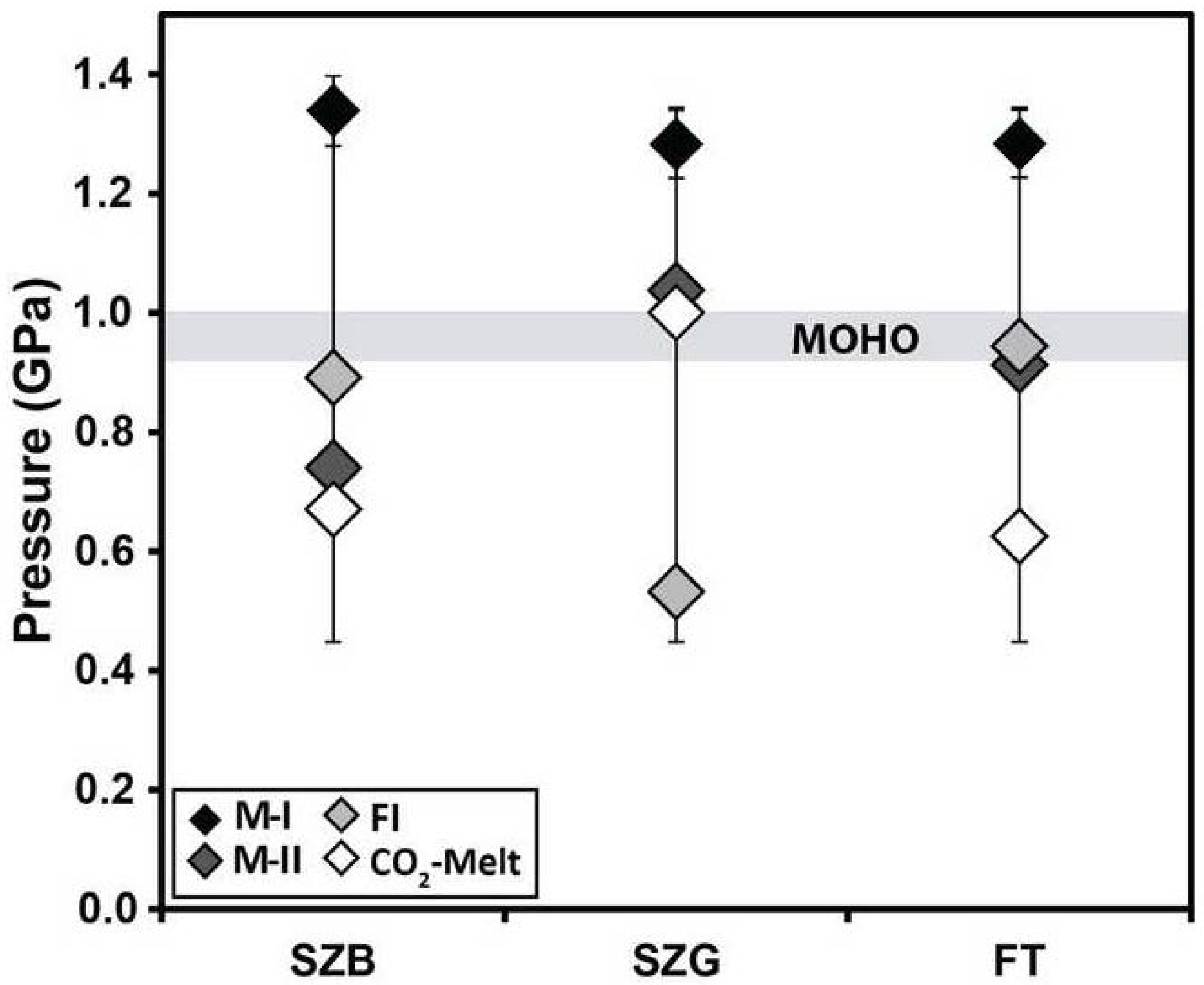


Click here to download high resolution image
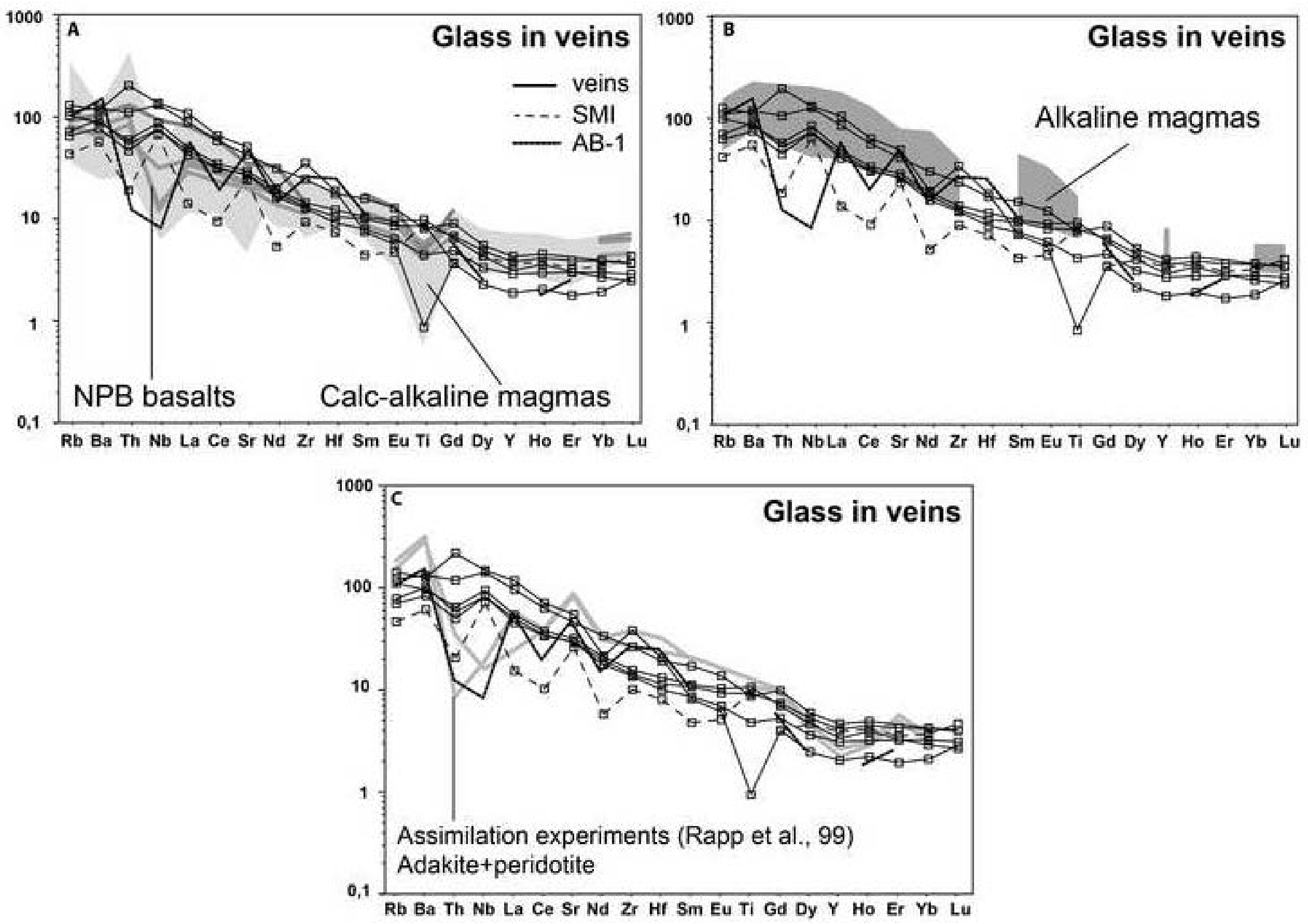


\section{Figure 14}

Click here to download high resolution image
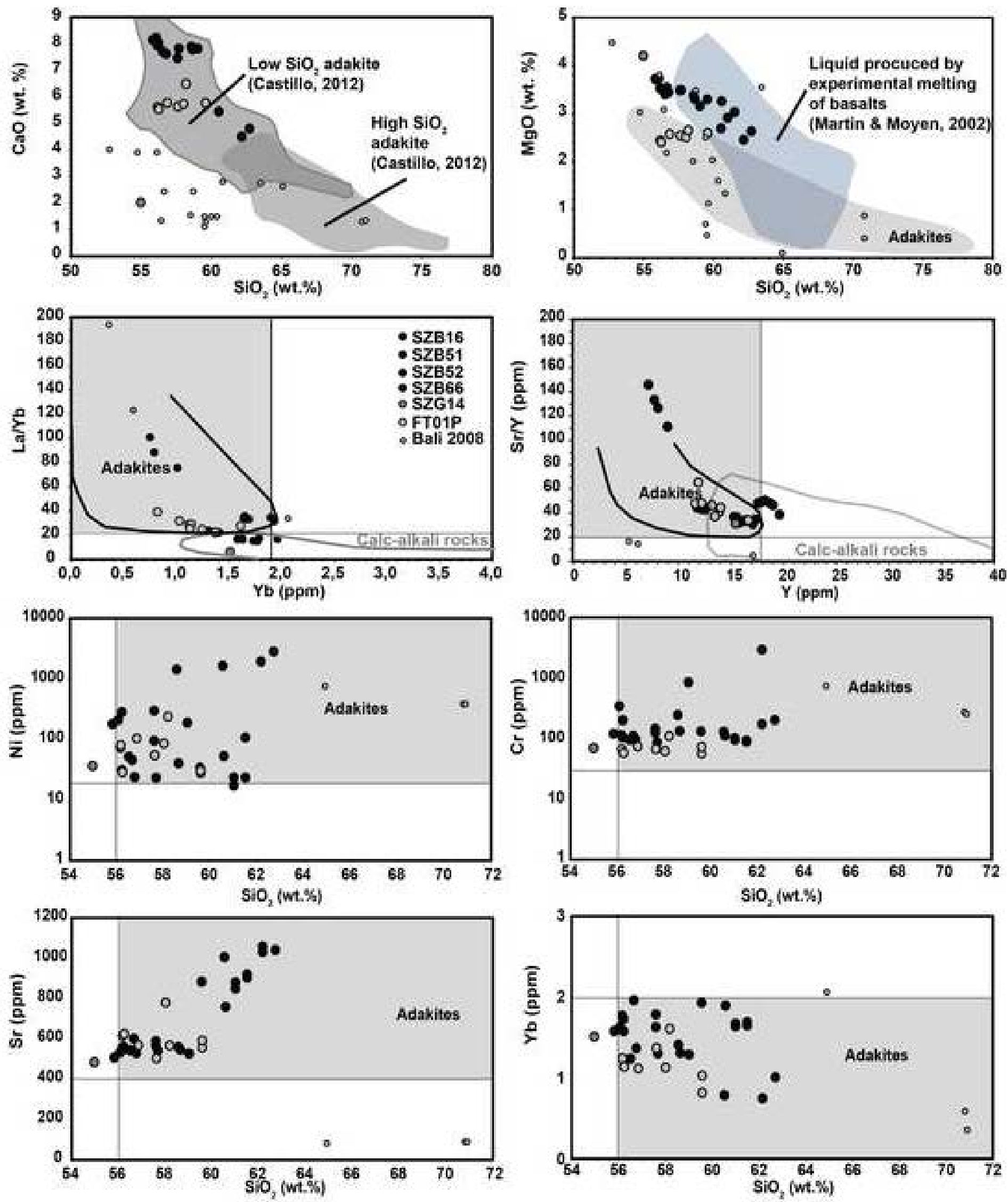

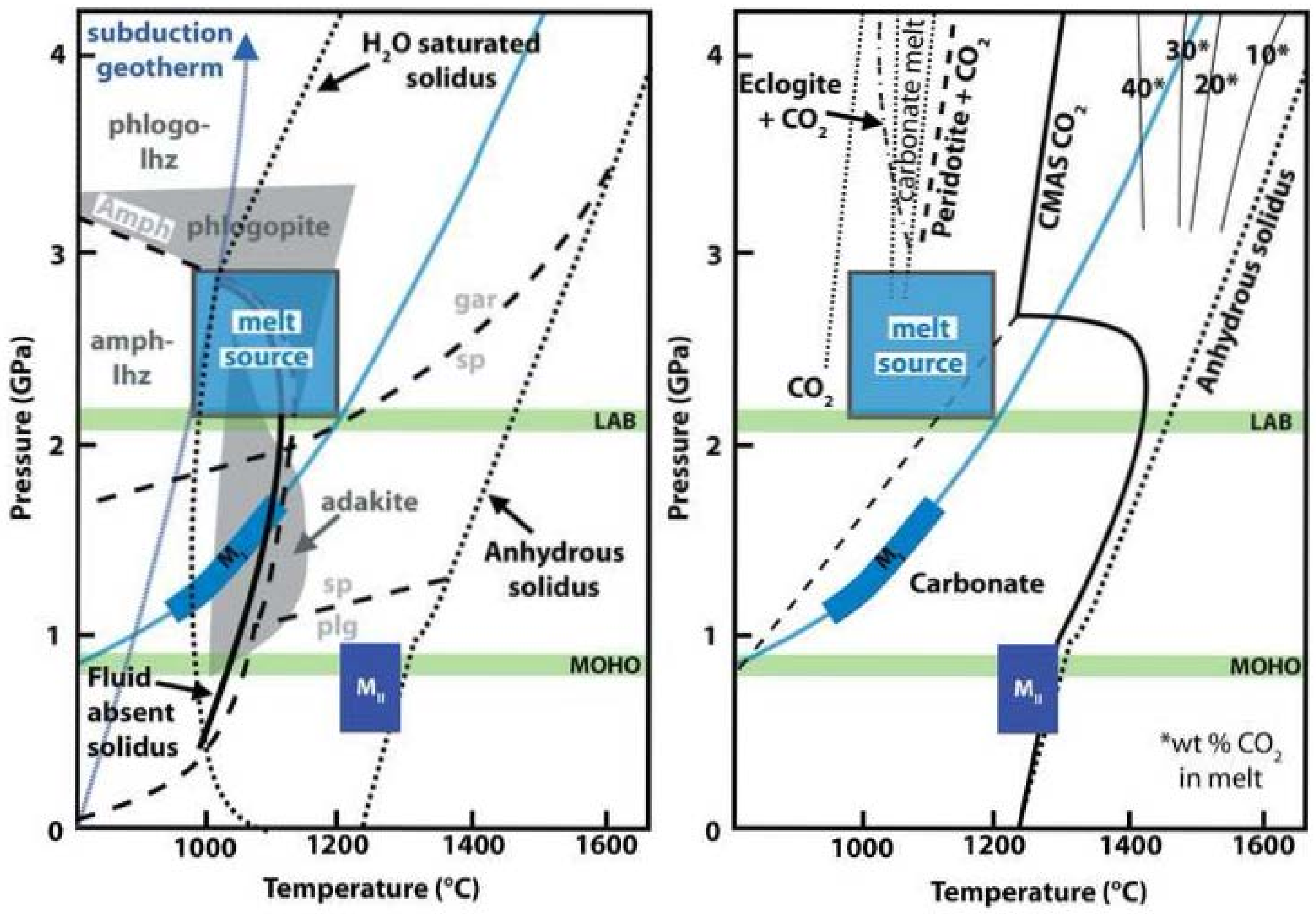


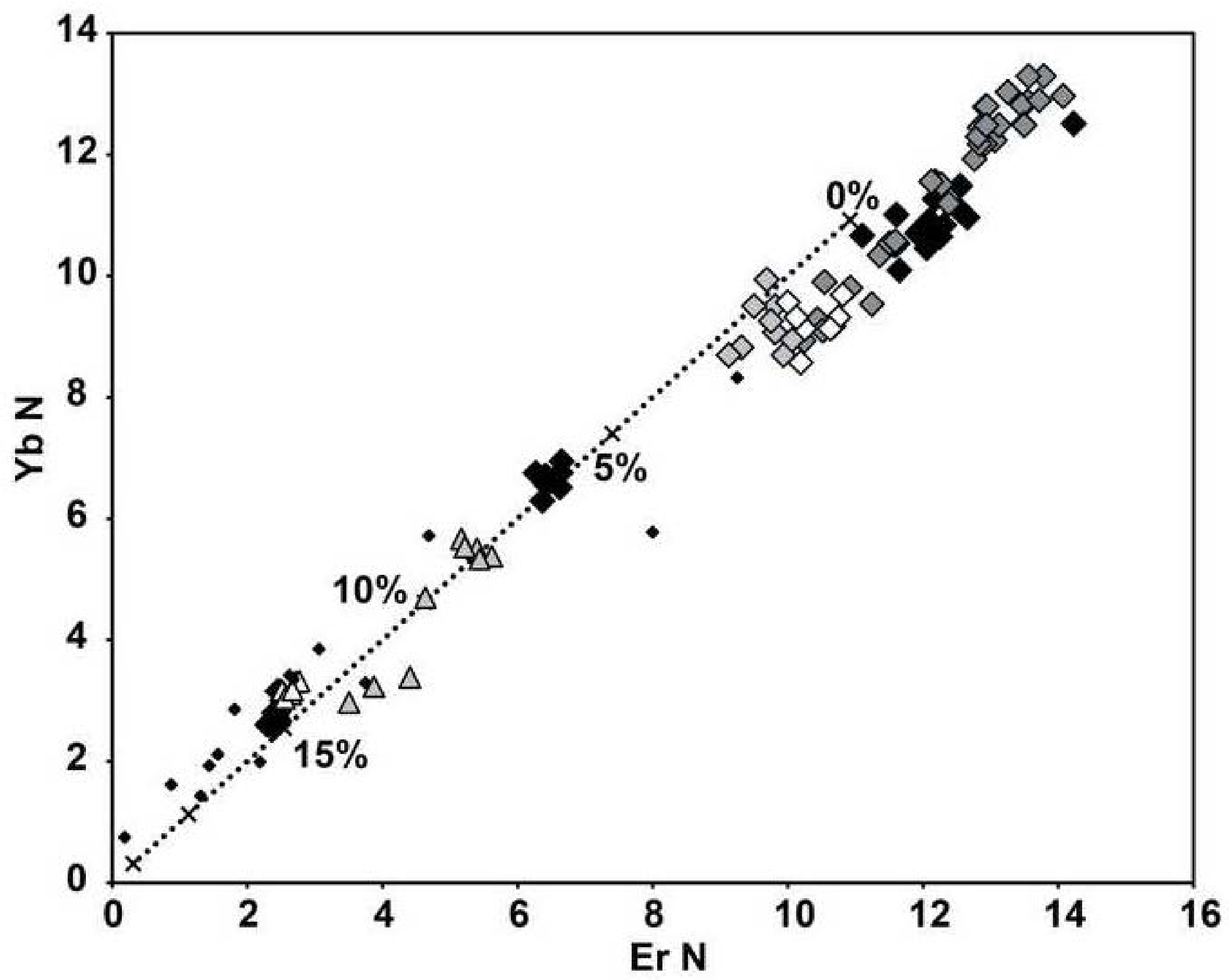




\begin{tabular}{|c|c|c|c|c|c|c|c|c|c|c|}
\hline Sample & $\begin{array}{l}\text { Whole } \\
\text { size }\end{array}$ & Grain size & & Texture & Minerals & $\begin{array}{l}\text { Rock } \\
\text { name }\end{array}$ & $\begin{array}{c}\text { Fluid } \\
\text { inclusions }\end{array}$ & Melt & $\begin{array}{c}2^{\text {nd }} \\
\text { Minerals }\end{array}$ & Major petrographic characters \\
\hline SZB16 & $9 \mathrm{~cm}$ & $<1$ to $>3 \mathrm{~mm}$ & $\mathrm{H}$ & Protogranular & $\begin{array}{l}\text { Ol, Opx, } \\
\text { Cpx, Sp }\end{array}$ & $\mathrm{Lz}$ & $2^{\text {ndary }}$ & Vein & $\begin{array}{l}\mathrm{Ol}, \mathrm{Cpx} \\
\quad \mathrm{Sp}\end{array}$ & $\begin{array}{l}\text { Minerals in contact with melt are broken-down. Phyllosilicates } \\
\text { observed in vein. Some Gl (S) observed }\end{array}$ \\
\hline SZB44 & $7 \mathrm{~cm}$ & $<1 \mathrm{~mm}$ & $\mathrm{E}$ & $\begin{array}{l}\text { Mosaic + Poikilitic } \\
\text { features }\end{array}$ & $\begin{array}{l}\text { Ol, Opx, } \\
\text { Cpx, Sp }\end{array}$ & $\mathrm{Lz}$ & $2^{\text {ndary }}$ & MP & $\begin{array}{l}\mathrm{Ol}, \mathrm{Cpx} \\
\mathrm{Sp}\end{array}$ & Spongy Sp at melt contact. Some Gl (S) observed \\
\hline SZB50 & $7 \mathrm{~cm}$ & $\sim 1 \mathrm{~mm}$ & $\mathrm{E}$ & Mosaic & $\begin{array}{l}\text { Ol, Opx, } \\
\text { Cpx, Sp }\end{array}$ & $\mathrm{Lz}$ & $2^{\text {ndary }}$ & $\begin{array}{l}\text { Vein } \\
+\mathrm{MP}\end{array}$ & $\begin{array}{l}\mathrm{Ol}, \mathrm{Cpx} \\
\mathrm{Sp}\end{array}$ & Spongy Sp. Gl (S) sometimes associated with FI \\
\hline SZB51 & $11 \mathrm{~cm}$ & 1 to $5 \mathrm{~mm}$ & $\mathrm{H}$ & Protogranular & $\begin{array}{l}\text { Ol, Opx, } \\
\text { Cpx, Sp }\end{array}$ & $\mathrm{Lz}$ & $2^{\text {ndary }}$ & MP & $\begin{array}{l}\mathrm{Ol}, \mathrm{Cpx} \\
\mathrm{Sp}\end{array}$ & $\begin{array}{l}\text { Spongy Sp. Large Gl (S) in melt. Melt pocket formed from Cpx } \\
\text { breakdown }\end{array}$ \\
\hline SZB52 & $9 \mathrm{~cm}$ & $<1$ to $5 \mathrm{~mm}$ & $\mathrm{H}$ & Protogranular & $\begin{array}{l}\text { Ol, Opx } \\
\text { Cpx, Sp }\end{array}$ & $\mathrm{Lz}$ & $2^{\text {ndary }}$ & Vein & $\begin{array}{l}\mathrm{Ol}, \mathrm{Cpx} \\
\quad \mathrm{Sp}\end{array}$ & $\begin{array}{l}\text { Large vein. No mineral breakdown. Gl (S) sometimes associated } \\
\text { with FI }\end{array}$ \\
\hline SZB66 & $18 \mathrm{~cm}$ & 4 to $6 \mathrm{~mm}$ & $\mathrm{E}$ & $\begin{array}{l}\text { Protogranular }+ \\
\text { Poikilitic features }\end{array}$ & $\begin{array}{l}\text { Ol, Opx, } \\
\text { Cpx, Sp }\end{array}$ & $\mathrm{Lz}$ & $2^{\text {ndary }}$ & Vein & $\begin{array}{l}\mathrm{Ol}, \mathrm{Cpx} \\
\mathrm{Sp}\end{array}$ & $\begin{array}{l}\text { Poikilitic Ol (containing Opx). Little reaction between melt and } \\
\text { minerals }\end{array}$ \\
\hline SZG14 & $7 \mathrm{~cm}$ & $\sim 1 \mathrm{~mm}$ & $\mathrm{E}$ & Protogranular & $\begin{array}{l}\text { Ol, Opx, } \\
\mathrm{Cpx}, \mathrm{Sp}\end{array}$ & $\mathrm{Lz}$ & $2^{\text {ndary }}$ & $\begin{array}{c}\text { Vein }+ \\
\text { SMI }\end{array}$ & $\begin{array}{l}\text { Ol, Cpx } \\
\text { Sp }\end{array}$ & Poikilitic Opx (containing Ol). Spongy Opx \\
\hline SZG23 & $7 \mathrm{~cm}$ & $<1$ to $4 \mathrm{~mm}$ & $\mathrm{H}$ & Protogranular & $\begin{array}{l}\text { Ol, Opx, } \\
\text { Cpx, Sp }\end{array}$ & $\mathrm{Lz}$ & $2^{\text {ndary }}$ & $\begin{array}{l}\text { MP + } \\
\text { Vein }\end{array}$ & $\begin{array}{l}\mathrm{Ol}, \mathrm{Cpx} \\
\mathrm{Sp}\end{array}$ & Lot of melt and fluid percolation. Lot of oxides in melt pockets \\
\hline SZG30 & $5 \mathrm{~cm}$ & $\sim 1 \mathrm{~mm}$ & $\mathrm{E}$ & Mosaic & $\begin{array}{l}\text { Ol, Opx, } \\
\text { Cpx, Sp + } \\
\text { Amph }\end{array}$ & $\mathrm{Lz}$ & $2^{\text {ndary }}$ & Vein & $\begin{array}{l}\mathrm{Ol}, \mathrm{Cpx} \\
\mathrm{Sp}\end{array}$ & $\begin{array}{l}\text { Lot of carbonate melts + fluid. Amph are broken-down. Gl (S), } \\
\text { carbonate melts veins and FI }\end{array}$ \\
\hline SZG44 & $7 \mathrm{~cm}$ & $\sim 1-2 \mathrm{~mm}$ & $\mathrm{E}$ & $\begin{array}{l}\text { Protogranular with } \\
\text { Mosaic tendency }\end{array}$ & $\begin{array}{l}\text { Ol, Opx } \\
\text { Cpx, Sp }\end{array}$ & $\mathrm{Lz}$ & $2^{\text {ndary }}$ & $\begin{array}{l}\text { Vein }+ \\
\text { Pockets }\end{array}$ & $\begin{array}{l}\mathrm{Ol}, \mathrm{Cpx} \\
\mathrm{Sp}\end{array}$ & $\begin{array}{l}\mathrm{Ol} \text { and } \mathrm{Cpx} \text { are destabilized at melt contact. Gl (S) observed at } \\
\text { melt/minerals boundaries }\end{array}$ \\
\hline FT12 & $9 \mathrm{~cm}$ & $\sim 1 \mathrm{~mm}$ & $\mathrm{E}$ & Mosaic & $\begin{array}{c}\text { Ol, Opx, } \\
\text { Cpx, Sp + } \\
\text { Amph }\end{array}$ & $\mathrm{Lz}$ & $2^{\text {ndary }}$ & $\begin{array}{l}\mathrm{MP}+ \\
\text { Vein }\end{array}$ & $\begin{array}{l}\mathrm{Ol}, \mathrm{Cpx} \\
\mathrm{Sp}\end{array}$ & $\begin{array}{l}\text { Broken-down Amph at melt contact. Some Gl (S) at grain } \\
\text { boundaries }\end{array}$ \\
\hline FT01P & $12 \mathrm{~cm}$ & $<1$ to $5 \mathrm{~mm}$ & $\mathrm{H}$ & Protogranular & $\begin{array}{l}\text { Ol, Opx, } \\
\mathrm{Cpx}, \mathrm{Sp}\end{array}$ & $\mathrm{Hzb}$ & $2^{\text {ndary }}$ & Vein & $\begin{array}{l}\mathrm{Ol}, \mathrm{Cpx} \\
\quad \mathrm{Sp}\end{array}$ & $\begin{array}{l}\text { Gl (S) sometimes associated with FI. Cryptic metasomatism. } \\
\text { Newly formed minerals at grain boundaries }\end{array}$ \\
\hline FT08P & $8 \mathrm{~cm}$ & 1 to $2 \mathrm{~mm}$ & $\mathrm{E}$ & Tabular & $\begin{array}{c}\text { Ol, Opx, } \\
\text { Cpx, Sp + } \\
\text { Amph }\end{array}$ & $\mathrm{Hzb}$ & $2^{\text {ndary }}$ & $\begin{array}{l}\text { Vein } \\
+\mathrm{Mp}\end{array}$ & $\begin{array}{l}\text { Ol, Cpx } \\
\quad \mathrm{Sp}\end{array}$ & $\begin{array}{l}\text { Gl (S) observed. Broken-down Amph with CpxII crystallization. } \\
\text { Beginning of Opx break-down }\end{array}$ \\
\hline $\begin{array}{l}\text { MSZK1306 } \\
\text { A }\end{array}$ & $2.5 \mathrm{~cm}$ & $<1$ to $3 \mathrm{~mm}$ & $\mathrm{H}$ & Protogranular & $\begin{array}{c}\text { Ol, Opx, } \\
\text { Cpx, Sp + } \\
\text { Amph }\end{array}$ & $\mathrm{Hzb}$ & $2^{\text {ndary }}$ & Vein & $\begin{array}{l}\mathrm{Ol}, \mathrm{Cpx} \\
\mathrm{Sp}\end{array}$ & $\begin{array}{l}\text { Broken-down Cpx at melt contact. Sp are enclosed in minerals } \\
\text { (Poikilitic features). Little destabilization of Amph }\end{array}$ \\
\hline MSZK1308 & $7 \mathrm{~cm}$ & $<1$ to $5 \mathrm{~mm}$ & $\mathrm{H}$ & $\begin{array}{l}\text { Protogranular }+ \\
\text { Poikilitic features }\end{array}$ & $\begin{array}{l}\text { Ol, Opx, } \\
\text { Cpx, Sp }\end{array}$ & $\mathrm{Lz}$ & $2^{\text {ndary }}$ & Vein & $\begin{array}{l}\mathrm{Ol}, \mathrm{Cpx} \\
\mathrm{Sp}\end{array}$ & $\mathrm{Gl}(\mathrm{S})$ in melt and sometimes associated with FI \\
\hline
\end{tabular}

Table 1: Petrographic description of BBHVF mantle xenoliths. H- heterogranular, E- equigranular, Lz- Lherzolite, Hzb- Harzburgite, 2ndarytrails of secondary fluid inclusions, Gl (s)- sulfide globule. 


\begin{tabular}{|c|c|c|c|c|c|c|c|c|c|c|c|c|c|c|c|c|c|c|c|c|c|c|c|c|c|c|c|c|c|c|}
\hline \multicolumn{31}{|l|}{ Olivine } \\
\hline Sample & SZB16 & & SZB44 & & SZB50 & & SZB51 & & SZB52 & & SZB66 & & SZG14 & & SZG23 & & SZG30 & & SZG44 & & FT12 & & FT01P & & FT08P & & MSZK1306A & & MSZK1308 & \\
\hline$n=$ & 8 & $1 \sigma$ & 3 & $1 \sigma$ & 2 & $1 \sigma$ & 4 & $1 \sigma$ & 4 & $1 \sigma$ & 3 & $1 \sigma$ & 6 & $1 \sigma$ & 3 & $1 \sigma$ & 4 & $1 \sigma$ & 4 & $1 \sigma$ & 4 & $1 \sigma$ & 2 & $1 \sigma$ & 6 & $1 \sigma$ & 2 & $1 \sigma$ & 4 & $1 \sigma$ \\
\hline$\overline{\mathrm{SiO}_{2}}$ & 40,97 & 0,21 & 40,9 & 0,24 & 40,43 & 0,27 & 41,56 & 0,15 & 40,84 & 0,3 & 41,04 & 0,09 & 41,05 & 0,22 & 40,8 & 0,47 & 41,47 & 0,34 & 41,26 & 0,3 & 40,96 & 0,23 & 42,09 & 0,12 & 41,56 & 0,17 & 41,31 & 0,41 & 41,39 & 41,39 \\
\hline $\mathrm{TiO}_{2}$ & 0,02 & 0,02 & 0,01 & 0,01 & 0 & 0 & 0,01 & 0,01 & 0,02 & 0,03 & 0 & 0 & 0,01 & 0,01 & 0 & 0,01 & 0,02 & 0,02 & 0,02 & 0,02 & 0 & 0 & 0,01 & 0,01 & 0 & 0 & 0 & 0 & 0,01 & 0,01 \\
\hline $\mathrm{Al}_{2} \mathrm{O}_{3}$ & 0,05 & 0,03 & 0,03 & 0,02 & 0,1 & 0,08 & 0,03 & 0,02 & 0,04 & 0,01 & 0,03 & 0,01 & 0,06 & 0,03 & 0,06 & 0,04 & 0,03 & 0,02 & 0,03 & 0,02 & 0,02 & 0,02 & 0,05 & 0,01 & 0,02 & 0,03 & 0,01 & 0 & 0,04 & 0,04 \\
\hline $\mathrm{Cr}_{2} \mathrm{O}_{3}$ & 0,02 & 0,02 & 0,03 & 0,05 & 0,01 & 0,01 & 0,07 & 0,08 & 0,07 & 0,04 & 0,06 & 0,04 & 0,03 & 0,04 & 0,05 & 0,02 & 0,02 & 0,04 & 0,04 & 0,05 & 0,02 & 0,01 & 0,04 & 0,01 & 0,03 & 0,04 & 0,02 & 0,01 & 0,03 & 0,03 \\
\hline $\mathrm{FeO}$ & 10,19 & 0,1 & 10,78 & 0,1 & 10,68 & 0,05 & 9,5 & 0,13 & 9,24 & 0,13 & 9,74 & 0,29 & 10,31 & 0,12 & 9,93 & 0,13 & 10,04 & 0,09 & 10,37 & 0,1 & 10,45 & 0,17 & 9,28 & 0,1 & 9,56 & 0,09 & 9,22 & 0,08 & 9,43 & 9,43 \\
\hline MnO & 0,13 & 0,03 & 0,13 & 0,04 & 0,12 & 0,03 & 0,12 & 0,01 & 0,14 & 0,01 & 0,12 & 0,02 & 0,15 & 0,03 & 0,15 & 0,04 & 0,13 & 0,01 & 0,15 & 0,02 & 0,15 & 0,02 & 0,15 & 0,03 & 0,14 & 0,02 & 0,13 & 0,02 & 0,13 & 0,13 \\
\hline $\mathrm{NiO}$ & 0,36 & 0,03 & 0,35 & 0,02 & 0,36 & 0,02 & 0,35 & 0,02 & 0,36 & 0,02 & 0,4 & 0,02 & 0 & 0 & 0 & 0 & 0 & 0 & 0 & 0 & 0 & 0 & 0 & 0 & 0 & 0 & 0 & 0 & 0 & 0 \\
\hline MgO & 48,77 & 0,13 & 48,16 & 0,25 & 48,06 & 0,03 & 49,08 & 0,12 & 48,99 & 0,24 & 48,59 & 0,22 & 48,35 & 0,12 & 48,17 & 0,08 & 48,37 & 0,21 & 48,17 & 0,15 & 48,22 & 0,47 & 48,78 & 0,01 & 49,54 & 0,29 & 49,98 & 0,15 & 49,31 & 49,31 \\
\hline $\mathrm{CaO}$ & 0,09 & 0,01 & 0,07 & 0,01 & 0,05 & 0 & 0,07 & 0,01 & 0,12 & 0,03 & 0,08 & 0,01 & 0,12 & 0,01 & 0,11 & 0,08 & 0,06 & 0,01 & 0,08 & 0,01 & 0,05 & 0,01 & 0,1 & 0,02 & 0,06 & 0,03 & 0,04 & 0,01 & 0,09 & 0,09 \\
\hline $\mathrm{Na}_{2} \mathrm{O}$ & 0,02 & 0,01 & 0,01 & 0,01 & 0 & 0 & 0,01 & 0,01 & 0,01 & 0,01 & 0,01 & 0,01 & 0,02 & 0,02 & 0,01 & 0 & 0,01 & 0 & 0,02 & 0,01 & 0 & 0 & 0,01 & 0,01 & 0,01 & 0,01 & 0 & 0 & 0,01 & 0,01 \\
\hline $\mathrm{K}_{2} \mathrm{O}$ & 0 & 0 & 0 & 0 & 0 & 0 & 0,01 & 0,01 & 0 & 0,01 & 0 & 0,01 & 0 & 0 & 0 & 0 & 0 & 0,01 & 0,01 & 0,01 & 0 & 0 & 0 & 0 & 0 & 0 & 0 & 0 & 0,01 & 0,01 \\
\hline $\mathrm{V}_{2} \mathrm{O}_{3}$ & 0 & 0 & 0 & 0 & 0 & 0 & 0 & 0 & 0 & 0 & 0 & 0 & 0,35 & 0,04 & 0,34 & 0,03 & 0,35 & 0,03 & 0,34 & 0,04 & 0,36 & 0,03 & 0,37 & 0,01 & 0,38 & 0,02 & 0,38 & 0,02 & 0,37 & 0,37 \\
\hline Total & 100,62 & 0,3 & 100,47 & 0,21 & 99,81 & 0,07 & 100,81 & 0,17 & 99,83 & 0,44 & 100,08 & 0,38 & 100,45 & 0,21 & 99,62 & 0,37 & 100,51 & 0,28 & 100,48 & 0,31 & 100,25 & 0,27 & 100,87 & 0,23 & 101,3 & 0,31 & 101,1 & 0,64 & 100,82 & 100,82 \\
\hline mg\# & 89,51 & 0,09 & 88,85 & 0,12 & 88,92 & 0,04 & 90,21 & 0,11 & 90,43 & 0,1 & 89,89 & 0,26 & 89,32 & 0,11 & 89,64 & 0,14 & 89,19 & 0,26 & 89,23 & 0,07 & 89,16 & 0,22 & 90,36 & 0,09 & 90,23 & 0,09 & 90,63 & 0,05 & 90,31 & 90,31 \\
\hline \multicolumn{31}{|l|}{ Opx } \\
\hline Sample & SZB16 & & SZB44 & & SZB50 & & SZB51 & & SZB52 & & SZB66 & & SZG14 & & SZG23 & & SZG30 & & SZG44 & & FT12 & & FT01P & & FT08P & & MSZK1306A & & MSZK1308 & \\
\hline$n=$ & 7 & $1 \sigma$ & 3 & $1 \sigma$ & 5 & $1 \sigma$ & 4 & $1 \sigma$ & 2 & $1 \sigma$ & 3 & $1 \sigma$ & 7 & $1 \sigma$ & 3 & $1 \sigma$ & 4 & $1 \sigma$ & 3 & $1 \sigma$ & 3 & $1 \sigma$ & 4 & $1 \sigma$ & 5 & $1 \sigma$ & 3 & $1 \sigma$ & 5 & $1 \sigma$ \\
\hline $\mathrm{SiO}_{2}$ & 54,21 & 0,48 & 55,41 & 0,76 & 55,23 & 0.19 & 56,62 & 33,45 & 55,45 & 1,15 & 56,19 & 0,2 & 54,91 & 0,29 & 55,25 & 0,54 & 55,34 & 0,45 & 54,92 & 0,23 & 55,17 & 0,21 & 56,55 & 0,23 & 56,45 & 0,27 & 56,82 & 0,43 & 55,44 & 0,23 \\
\hline $\mathrm{TiO}_{2}$ & 0,15 & 0,02 & 0,09 & 0,02 & 0,1 & 0.03 & 0,04 & 33,45 & 0,06 & 0,02 & 0,04 & 0,02 & 0,16 & 0,03 & 0,09 & 0,05 & 0,14 & 0,04 & 0,16 & 0,01 & 0,08 & 0,03 & 0,09 & 0,03 & 0,04 & 0,03 & 0,03 & 0,04 & 0,12 & 0,03 \\
\hline $\mathrm{Al}_{2} \mathrm{O}_{3}$ & 5,7 & 0,09 & 4,59 & 0,14 & 4,5 & 0.06 & 2,8 & 33,45 & 5,04 & 0,19 & 3,12 & 0,06 & 5,18 & 0,16 & 3,98 & 0,22 & 4,84 & 0,09 & 5,12 & 0,07 & 4,26 & 0,07 & 3,33 & 0,05 & 3,48 & 0,07 & 2,61 & 0,07 & 5,08 & 0,07 \\
\hline $\mathrm{Cr}_{2} \mathrm{O}_{3}$ & 0,44 & 0,05 & 0,29 & 0,02 & 0,24 & 0.03 & 0,61 & 33,45 & 0,57 & 0,01 & 0,61 & 0,05 & 0,34 & 0,04 & 0,59 & 0,03 & 0,4 & 0,03 & 0,37 & 0,03 & 0,29 & 0,04 & 0,8 & 0,04 & 0,34 & 0,04 & 0,35 & 0,05 & 0,5 & 0,03 \\
\hline FeO & 6,52 & 0,12 & 6,76 & 0,16 & 6,91 & 0.13 & 5,98 & 3,05 & 5,81 & 0,12 & 6,3 & 0,05 & 6,47 & 0,13 & 6,49 & 0,19 & 6,34 & 0,14 & 6,57 & 0,05 & 6,79 & 0,1 & 5,81 & 0,12 & 6,34 & 0,07 & 6,08 & 0,12 & 5,91 & 0,1 \\
\hline Mno & 0,1 & 0,03 & 0,14 & 0,03 & 0,13 & 0.05 & 0,11 & 33,45 & 0,13 & 0,03 & 0,14 & 0,04 & 0,12 & 0,03 & 0,13 & 0,03 & 0,13 & 0,03 & 0,13 & 0,03 & 0,14 & 0,02 & 0,09 & 0,01 & 0,14 & 0,03 & 0,13 & 0,02 & 0,11 & 0,03 \\
\hline NiO & 0,09 & 0,04 & 0,08 & 0,01 & 0,09 & 0.02 & 0,08 & 0,46 & 0,1 & 0,02 & 0,1 & 0,02 & 0,01 & 0 & 0,01 & 0 & 0,02 & 0,01 & 0,01 & 0 & 0,01 & 0,01 & 0,02 & 0 & 0,01 & 0 & 0,01 & 0 & 0,01 & 0 \\
\hline $\mathrm{MgO}$ & 31,62 & 0,41 & 32,2 & 0,5 & 32,35 & 0.12 & 33,24 & 33,45 & 31,98 & 0,14 & 32,77 & 0,09 & 31,94 & 0,22 & 32,08 & 0,44 & 32,29 & 0,19 & 31,93 & 0,16 & 32,48 & 0,08 & 32,38 & 0,22 & 33,74 & 0,16 & 34,28 & 0,17 & 32,51 & 0,13 \\
\hline $\mathrm{CaO}$ & 1,03 & 0,02 & 0,75 & 0,08 & 0,68 & 0.02 & 0,81 & 33,45 & 1,12 & 0,01 & 0,89 & 0,03 & 0,88 & 0,1 & 0,84 & 0,03 & 0,78 & 0,02 & 0,83 & 0,03 & 0,69 & 0,03 & 1,17 & 0,05 & 0,6 & 0,02 & 0,6 & 0,01 & 0,93 & 0,02 \\
\hline $\mathrm{Na}_{2} \mathrm{O}$ & 0,18 & 0,01 & 0,06 & 0,01 & 0,07 & 0.00 & 0,06 & 33,45 & 0,09 & 0,01 & 0,02 & 0,01 & 0,15 & 0,02 & 0,16 & 0,01 & 0,11 & 0,01 & 0,15 & 0,01 & 0,05 & 0,01 & 0,13 & 0,01 & 0,02 & 0,01 & 0,02 & 0,03 & 0,12 & 0,01 \\
\hline $\mathbf{K}_{2} \mathbf{O}$ & 0,01 & 0,01 & 0,01 & 0,01 & 0,01 & 0.01 & 0 & 33,45 & 0,01 & 0,01 & 0 & 0,01 & 0,01 & 0,01 & 0 & 0 & 0 & 0 & 0,01 & 0,01 & 0 & 0 & 0 & 0 & 0,01 & 0,01 & 0 & 0,01 & 0 & 0 \\
\hline $\mathrm{V}_{2} \mathrm{O}_{3}$ & 0,02 & 0 & 0,01 & 0,01 & 0,02 & 0.00 & 0,01 & 33,45 & 0,01 & 0 & 0,02 & 0 & 0,09 & 0,02 & 0,08 & 0,01 & 0,09 & 0,01 & 0,09 & 0,01 & 0,09 & 0 & 0,1 & 0,02 & 0,09 & 0,02 & 0,09 & 0,02 & 0,1 & 0,02 \\
\hline Total & 100,06 & 0,84 & 100,4 & 0,42 & 100,33 & 0.29 & 100,36 & 4,96 & 100,38 & 1,47 & 100,19 & 0,35 & 100,28 & 0,35 & 99,7 & 0,32 & 100,48 & 0,67 & 100,29 & 0,21 & 100,07 & 0,27 & 100,47 & 0,31 & 101,27 & 0,25 & 101,03 & 0,5 & 100,84 & 0,29 \\
\hline mg\# & 89,62 & 0,17 & 89,47 & 0,19 & 89,3 & 0.16 & 90,83 & 38,44 & 90,75 & 0,15 & 90,27 & 0,08 & 89,8 & 0,17 & 89,81 & 0,37 & 90,08 & 0,2 & 89,65 & 0,1 & 89,5 & 0,12 & 90,85 & 0,17 & 90,46 & 0,1 & 90,96 & 0,17 & 90,74 & 0,12 \\
\hline
\end{tabular}




\begin{tabular}{|c|c|c|c|c|c|c|c|c|c|c|c|c|c|c|c|c|c|c|c|c|c|c|c|c|c|c|c|c|c|c|}
\hline \multicolumn{31}{|l|}{ Cpx } \\
\hline Sample & SZB16 & & SZB44 & & SZB50 & & SZB51 & & SZB52 & & SZB66 & & SZG14 & & SZG23 & & SZG30 & & SZG44 & & FT12 & & FT01P & & FT08P & & MSZK1306A & & MSZK1308 & \\
\hline$n=$ & 9 & $1 \sigma$ & 3 & $1 \sigma$ & 5 & $1 \sigma$ & 4 & $1 \sigma$ & 3 & $1 \sigma$ & 3 & $1 \sigma$ & 7 & $1 \sigma$ & 4 & $1 \sigma$ & 3 & $1 \sigma$ & 3 & $1 \sigma$ & 3 & $1 \sigma$ & 2 & $1 \sigma$ & 4 & $1 \sigma$ & 4 & $1 \sigma$ & 6 & $1 \sigma$ \\
\hline $\mathrm{SiO}_{2}$ & 51,55 & 0,21 & 52,10 & 0,22 & 52,39 & 0,33 & 53,73 & 0,30 & 51,99 & 0,27 & 53,01 & 0,46 & 51,65 & 0,68 & 51,88 & 0,70 & 52,25 & 0,34 & 51,93 & 0,20 & 52,32 & 0,29 & 53,97 & 0,36 & 53,34 & 0,32 & 53,83 & 0,18 & 52,25 & 0,23 \\
\hline $\mathrm{TiO}_{2}$ & 0,59 & 0,06 & 0,37 & 0,03 & 0,34 & 0,01 & 0,06 & 0,03 & 0,17 & 0,01 & 0,06 & 0,02 & 0,66 & 0,14 & 0,40 & 0,14 & 0,49 & 0,05 & 0,62 & 0,05 & 0,32 & 0,03 & 0,22 & 0,01 & 0,14 & 0,03 & 0,05 & 0,03 & 0,46 & 0,03 \\
\hline $\mathrm{Al}_{2} \mathrm{O}_{3}$ & 7,38 & 0,54 & 5,65 & 0,07 & 5,69 & 0,06 & 3,36 & 0,09 & 5,84 & 0,05 & 3,32 & 0,06 & 7,54 & 0,27 & 6,13 & 0,24 & 6,84 & 0,12 & 7,40 & 0,07 & 5,38 & 0,05 & 4,12 & 0,01 & 3,36 & 0,14 & 2,29 & 0,05 & 6,70 & 0,06 \\
\hline $\mathrm{Cr}_{2} \mathrm{O}_{3}$ & 0,81 & 0,04 & 0,47 & 0,02 & 0,44 & 0,04 & 1,07 & 0,08 & 1,03 & 0,04 & 0,86 & 0,07 & 0,70 & 0,03 & 1,23 & 0,07 & 0,77 & 0,03 & 0,71 & 0,03 & 0,51 & 0,06 & 1,41 & 0,09 & 0,40 & 0,06 & 0,35 & 0,05 & 0,93 & 0,05 \\
\hline $\mathrm{FeO}$ & 3,44 & 0,11 & 3,08 & 0,08 & 3,04 & 0,05 & 2,81 & 0,03 & 2,96 & 0,08 & 3,03 & 0,09 & 3,17 & 0,29 & 3,31 & 0,14 & 2,93 & 0,05 & 3,25 & 0,09 & 2,87 & 0,07 & 3,03 & 0,05 & 2,56 & 0,04 & 2,57 & 0,02 & 2,99 & 0,06 \\
\hline MnO & 0,08 & 0,02 & 0,07 & 0,02 & 0,07 & 0,02 & 0,04 & 0,02 & 0,04 & 0,02 & 0,04 & 0,03 & 0,08 & 0,03 & 0,03 & 0,01 & 0,05 & 0,02 & 0,07 & 0,01 & 0,06 & 0,01 & 0,04 & 0,03 & 0,06 & 0,02 & 0,06 & 0,02 & 0,07 & 0,01 \\
\hline NiO & 0,05 & 0,03 & 0,06 & 0,02 & 0,04 & 0,01 & 0,04 & 0,01 & 0,06 & 0,01 & 0,06 & 0,02 & 0,04 & 0,00 & 0,04 & 0,01 & 0,04 & 0,00 & 0,04 & 0,00 & 0,03 & 0,00 & 0,03 & 0,00 & 0,03 & 0,00 & 0,02 & 0,00 & 0,03 & 0,01 \\
\hline MgO & 15,46 & 0,37 & 15,71 & 0,05 & 15,65 & 0,15 & 16,90 & 0,09 & 16,41 & 0,13 & 16,91 & 0,32 & 15,20 & 0,29 & 14,96 & 0,11 & 15,35 & 0,10 & 14,86 & 0,09 & 15,70 & 0,07 & 16,80 & 0,16 & 16,74 & 0,31 & 17,51 & 0,11 & 15,69 & 0,06 \\
\hline $\mathrm{CaO}$ & 18,53 & 0,93 & 20,80 & 0,16 & 20,71 & 0,06 & 20,90 & 0,19 & 19,50 & 0,41 & 21,17 & 0,53 & 18,76 & 0,44 & 19,16 & 0,20 & 19,59 & 0,29 & 18,84 & 0,17 & 21,28 & 0,15 & 19,19 & 0,16 & 22,63 & 1,77 & 23,52 & 0,08 & 19,58 & 0,33 \\
\hline $\mathrm{Na}_{2} \mathrm{O}$ & 1,61 & 0,37 & 1,09 & 0,02 & 1,07 & 0,01 & 0,85 & 0,01 & 0,98 & 0,01 & 0,44 & 0,01 & 1,77 & 0,14 & 1,78 & 0,06 & 1,62 & 0,03 & 1,85 & 0,05 & 1,00 & 0,02 & 1,14 & 0,04 & 0,40 & 0,04 & 0,30 & 0,04 & 1,52 & 0,03 \\
\hline $\mathrm{K}_{2} \mathrm{O}$ & 0,02 & 0,03 & 0,01 & 0,01 & 0,00 & 0,00 & 0,00 & 0,00 & 0,01 & 0,00 & 0,00 & 0,00 & 0,00 & 0,00 & 0,01 & 0,00 & 0,00 & 0,00 & 0,00 & 0,00 & 0,00 & 0,00 & 0,00 & 0,00 & 0,00 & 0,00 & 0,01 & 0,01 & 0,01 & 0,01 \\
\hline $\mathrm{V}_{2} \mathrm{O}_{3}$ & 0,04 & 0,01 & 0,03 & 0,00 & 0,03 & 0,00 & 0,04 & 0,00 & 0,04 & 0,00 & 0,04 & 0,01 & 0,04 & 0,01 & 0,04 & 0,02 & 0,04 & 0,01 & 0,03 & 0,01 & 0,03 & 0,02 & 0,04 & 0,02 & 0,04 & 0,02 & 0,04 & 0,02 & 0,03 & 0,03 \\
\hline Total & 99,55 & 0,30 & 99,44 & 0,32 & 99,48 & 0,47 & 99,80 & 0,13 & 99,03 & 0,26 & 98,93 & 1,16 & 99,61 & 0,67 & 98,97 & 0,50 & 99,97 & 0,33 & 99,60 & 0,31 & 99,49 & 0,41 & 99,98 & 0,05 & 99,72 & 2,03 & 100,56 & 0,21 & 100,27 & 0,17 \\
\hline mg\# & 88,91 & 0,45 & 90,09 & 0,24 & 90,18 & 0,13 & 91,48 & 0,10 & 90,81 & 0,28 & 90,87 & 0,20 & 89,55 & 0,69 & 88,97 & 0,42 & 90,32 & 0,16 & 89,08 & 0,25 & 90,69 & 0,22 & 90,82 & 0,21 & 92,11 & 0,17 & 92,40 & 0,07 & 90,36 & 0,18 \\
\hline \multicolumn{31}{|l|}{ Sp } \\
\hline Sample & SZB16 & & SZB44 & & SZB50 & & SZB51 & & SZB52 & & SZB66 & & SZG14 & & SZG23 & & SZG30 & & SZG44 & & FT12 & & FT01P & & FT08P & & MSZK1306A & & MSZK1308 & \\
\hline$n=$ & 8 & $1 \sigma$ & 4 & $1 \sigma$ & 4 & $1 \sigma$ & 5 & $1 \sigma$ & 4 & $1 \sigma$ & 4 & $1 \sigma$ & 11 & $1 \sigma$ & 5 & $1 \sigma$ & 1 & $1 \sigma$ & 6 & $1 \sigma$ & 5 & $1 \sigma$ & 2 & $1 \sigma$ & 7 & $1 \sigma$ & 1 & $1 \sigma$ & 4 & $1 \sigma$ \\
\hline $\mathrm{SiO}_{2}$ & 0,11 & 0,02 & 0,06 & 0,01 & 0,07 & 0,01 & 0,63 & 1,30 & 0,07 & 0,02 & 0,12 & 0,11 & 0,10 & 0,03 & 0,06 & 0,03 & 0,06 & - & 0,07 & 0,02 & 0,05 & 0,02 & 0,08 & 0,02 & 0,03 & 0,03 & 0,01 & - & 0,06 & 0,02 \\
\hline $\mathrm{TiO}_{2}$ & 0,22 & 0,03 & 0,10 & 0,00 & 0,08 & 0,03 & 0,10 & 0,01 & 0,10 & 0,03 & 0,09 & 0,03 & 0,26 & 0,02 & 0,20 & 0,03 & 0,12 & - & 0,17 & 0,02 & 0,09 & 0,01 & 0,35 & 0,03 & 0,06 & 0,01 & 0,07 & - & 0,18 & 0,01 \\
\hline $\mathrm{Al}_{2} \mathrm{O}_{3}$ & 57,18 & 0,50 & 58,74 & 0,44 & 59,15 & 0,56 & 31,24 & 0,29 & 50,58 & 0,35 & 31,87 & 0,20 & 58,34 & 0,34 & 43,81 & 1,44 & 57,00 & - & 58,17 & 0,23 & 57,63 & 0,54 & 30,80 & 0,03 & 51,08 & 0,48 & 36,38 & - & 54,09 & 0,34 \\
\hline $\mathrm{Cr}_{2} \mathrm{O}_{3}$ & 9,77 & 0,14 & 8,30 & 0,25 & 7,77 & 0,34 & 35,40 & 0,46 & 16,72 & 0,20 & 31,20 & 0,73 & 8,62 & 0,14 & 21,63 & 1,34 & 10,62 & - & 8,72 & 0,21 & 9,44 & 0,24 & 35,92 & 0,14 & 15,83 & 0,39 & 28,07 & - & 13,50 & 0,24 \\
\hline $\mathrm{FeO}$ & 11,46 & 0,22 & 11,58 & 0,10 & 11,42 & 0,18 & 15,72 & 0,36 & 10,79 & 0,12 & 18,41 & 0,76 & 10,68 & 0,15 & 14,71 & 0,42 & 10,78 & - & 11,52 & 0,13 & 11,40 & 0,18 & 15,42 & 0,20 & 12,48 & 0,64 & 17,86 & - & 10,83 & 0,27 \\
\hline MnO & 0,00 & 0,00 & 0,00 & 0,00 & 0,00 & 0,00 & 0,00 & 0,00 & 0,00 & 0,00 & 0,00 & 0,00 & 0,00 & 0,00 & 0,00 & 0,00 & 0,00 & - & 0,00 & 0,00 & 0,00 & 0,00 & 0,00 & 0,00 & 0,00 & 0,00 & 0,00 & - & 0,00 & 0,00 \\
\hline $\mathrm{NiO}$ & 0,39 & 0,02 & 0,38 & 0,02 & 0,39 & 0,02 & 0,20 & 0,03 & 0,33 & 0,03 & 0,26 & 0,03 & 0,06 & 0,00 & 0,08 & 0,00 & 0,07 & - & 0,06 & 0,00 & 0,06 & 0,00 & 0,14 & 0,00 & 0,08 & 0,00 & 0,17 & - & 0,07 & 0,00 \\
\hline MgO & 20,59 & 0,14 & 20,16 & 0,11 & 20,16 & 0,06 & 15,50 & 0,23 & 19,61 & 0,24 & 15,90 & 0,67 & 21,06 & 0,17 & 18,08 & 0,24 & 20,68 & - & 20,62 & 0,11 & 20,10 & 0,21 & 16,26 & 0,03 & 19,32 & 0,54 & 16,47 & - & 20,52 & 0,05 \\
\hline $\mathrm{CaO}$ & 0,00 & 0,00 & 0,01 & 0,01 & 0,00 & 0,00 & 0,04 & 0,08 & 0,01 & 0,00 & 0,00 & 0,00 & 0,01 & 0,01 & 0,00 & 0,00 & 0,01 & - & 0,00 & 0,00 & 0,00 & 0,00 & 0,00 & 0,00 & 0,01 & 0,01 & 0,02 & - & 0,00 & 0,00 \\
\hline $\mathrm{Na}_{2} \mathrm{O}$ & 0,01 & 0,01 & 0,01 & 0,01 & 0,01 & 0,01 & 0,06 & 0,11 & 0,01 & 0,01 & 0,01 & 0,01 & 0,01 & 0,01 & 0,01 & 0,02 & 0,01 & - & 0,01 & 0,01 & 0,00 & 0,01 & 0,00 & 0,00 & 0,01 & 0,01 & 0,02 & - & 0,01 & 0,01 \\
\hline $\mathrm{K}_{2} \mathrm{O}$ & 0,00 & 0,01 & 0,00 & 0,01 & 0,02 & 0,02 & 0,02 & 0,04 & 0,01 & 0,01 & 0,01 & 0,01 & 0,00 & 0,00 & 0,00 & 0,00 & 0,00 & - & 0,00 & 0,00 & 0,00 & 0,00 & 0,00 & 0,00 & 0,00 & 0,00 & 0,00 & - & 0,01 & 0,01 \\
\hline $\mathbf{V}_{2} \mathbf{O}_{3}$ & 0,07 & 0,00 & 0,06 & 0,01 & 0,06 & 0,00 & 0,16 & 0,01 & 0,08 & 0,00 & 0,20 & 0,00 & 0,38 & 0,03 & 0,33 & 0,02 & 0,38 & - & 0,36 & 0,03 & 0,36 & 0,03 & 0,27 & 0,02 & 0,31 & 0,03 & 0,25 & - & 0,35 & 0,03 \\
\hline Total & 99,80 & 0,37 & 99,40 & 0,12 & 99,13 & 0,17 & 99,06 & 0,54 & 98,28 & 0,20 & 98,07 & 0,87 & 99,52 & 0,53 & 98,92 & 0,36 & 99,73 & - & 99,69 & 0,39 & 99,13 & 0,29 & 99,24 & 0,31 & 99,19 & 0,62 & 99,33 & - & 99,63 & 0,25 \\
\hline mg\# & 76,21 & 0,36 & 75,62 & 0,12 & 75,88 & 0,26 & 63,73 & 0,44 & 76,41 & 0,37 & 60,62 & 1,92 & 77,85 & 0,17 & 68,66 & 0,85 & 77,37 & - & 76,14 & 0,16 & 75,86 & 0,30 & 65,27 & 0,33 & 73,40 & 1,47 & 62,18 & - & 77,16 & 0,45 \\
\hline cr\# & 10,28 & 0,19 & 8,66 & 0,29 & 8,10 & 0,39 & 43,18 & 0,22 & 18,15 & 0,22 & 39,63 & 0,47 & 9,02 & 0,12 & 24,89 & 1,78 & 11,11 & - & 9,14 & 0,22 & 9,90 & 0,31 & 43,89 & 0,07 & 17,21 & 0,40 & 34,11 & - & 14,34 & 0,29 \\
\hline
\end{tabular}

Table 2: Major element composition of primary olivines, orthopyroxenes, clinopyroxènes and spinels (in wt. \%). 


\begin{tabular}{|c|c|c|c|c|c|c|c|c|c|c|c|c|c|c|c|c|c|c|c|c|c|c|c|c|c|c|c|c|c|c|c|c|}
\hline \multicolumn{11}{|c|}{ Olivine II } & \multicolumn{9}{|l|}{ Cpx II } & \multicolumn{13}{|l|}{ Sp II } \\
\hline Sample & SZB50 & & SZB51 & & SZG23 & & FT12 & & FT08P & & Sample & SZB16 & & SZB44 & & SZB50 & & SZB51 & & Sample & SZB50 & & SZB51 & & SZG23 & & SZG44 & & FT12 & & FT08P & \\
\hline$n=$ & 12 & $1 \sigma$ & 9 & $1 \sigma$ & 12 & $1 \sigma$ & 13 & $1 \sigma$ & 8 & $1 \sigma$ & $\mathrm{n}=$ & 2 & $1 \sigma$ & 3 & $1 \sigma$ & 4 & $1 \sigma$ & 4 & $1 \sigma$ & $\mathrm{n}=$ & 2 & $1 \sigma$ & 3 & $1 \sigma$ & 2 & $1 \sigma$ & 4 & $1 \sigma$ & 3 & $1 \sigma$ & 3 & $1 \sigma$ \\
\hline $\mathrm{SiO}_{2}$ & 41,06 & 0,43 & 41,51 & 0,35 & 41,38 & 1,10 & 41,78 & 0,58 & 41,62 & 0,42 & $\mathrm{SiO}_{2}$ & 52.21 & 0.03 & 49.39 & 2.87 & 50.56 & 2.54 & 51.15 & 1.26 & $\mathrm{SiO}_{2}$ & 0.06 & 0.03 & 8.88 & 15.32 & 0.09 & 0.04 & 0.10 & 0.02 & 0.08 & 0.00 & 1.06 & 1.69 \\
\hline $\mathrm{TiO}_{2}$ & 0,05 & 0,02 & 0,03 & 0,02 & 0,07 & 0,11 & 0,02 & 0,02 & 0,03 & 0,03 & $\mathrm{TiO}_{2}$ & 0.59 & 0.07 & 1.33 & 0.85 & 1.00 & 0.83 & 0.28 & 0.07 & $\mathrm{TiO}_{2}$ & 0.23 & 0.14 & 0.15 & 0.15 & 0.64 & 0.02 & 0.74 & 0.03 & 0.27 & 0.14 & 0.18 & 0.19 \\
\hline $\mathrm{Al}_{2} \mathrm{O}_{3}$ & 0,05 & 0,02 & 0,09 & 0,15 & 0,39 & 1,07 & 0,06 & 0,04 & 0,04 & 0,03 & $\mathrm{Al}_{2} \mathrm{O}_{3}$ & 7.67 & 0.14 & 8.95 & 2.91 & 7.25 & 2.11 & 6.99 & 1.39 & $\mathrm{Al}_{2} \mathrm{O}_{3}$ & 56.35 & 2.01 & 29.91 & 1.41 & 38.56 & 3.96 & 51.36 & 4.24 & 54.34 & 3.34 & 48.44 & 10.45 \\
\hline $\mathrm{Cr}_{2} \mathrm{O}_{3}$ & 0,08 & 0,05 & 0,10 & 0,04 & 0,11 & 0,05 & 0,07 & 0,04 & 0,11 & 0,05 & $\mathrm{Cr}_{2} \mathrm{O}_{3}$ & 0.00 & 0.00 & 0.00 & 0.00 & 0.00 & 0.00 & 0.00 & 0.00 & $\mathrm{Cr}_{2} \mathrm{O}_{3}$ & 10.85 & 2.04 & 28.48 & 14.72 & 25.60 & 4.58 & 15.21 & 4.83 & 12.31 & 2.81 & 18.00 & 7.36 \\
\hline $\mathrm{FeO}$ & 8,99 & 0,51 & 7,82 & 0,25 & 8,27 & 0,59 & 8,23 & 0,30 & 7,31 & 0,24 & $\mathrm{FeO}$ & 3.61 & 0.01 & 3.05 & 0.38 & 3.10 & 0.10 & 2.44 & 0.13 & FeO & 11.28 & 1.04 & 12.57 & 3.94 & 14.54 & 0.66 & 10.90 & 0.58 & 10.63 & 0.76 & 11.25 & 2.47 \\
\hline MnO & 0,12 & 0,03 & 0,10 & 0,03 & 0,12 & 0,03 & 0,13 & 0,03 & 0,10 & 0,03 & MnO & 0.04 & 0.06 & 0.10 & 0.06 & 0.06 & 0.02 & n.d. & 0.03 & MnO & n.d. & & n.d. & & n.d. & & n.d. & & n.d. & & n.d. & \\
\hline $\mathrm{NiO}$ & 0,35 & 0,04 & 0,34 & 0,05 & 0,31 & 0,05 & 0,31 & 0,04 & 0,42 & 0,05 & $\mathrm{NiO}$ & 0.00 & 0.00 & 0.00 & 0.00 & 0.00 & 0.00 & 0.00 & 0.00 & $\mathrm{NiO}$ & 0.42 & 0.01 & 0.18 & 0.07 & 0.26 & 0.01 & 0.36 & 0.07 & 0.39 & 0.02 & 0.36 & 0.08 \\
\hline MgO & 49,09 & 0,66 & 49,37 & 1,40 & 48,02 & 2,86 & 49,58 & 0,98 & 50,11 & 0,29 & $\mathrm{MgO}$ & 15.32 & 0.02 & 14.89 & 0.91 & 15.20 & 1.03 & 15.33 & 0.86 & MgO & 20.81 & 0.89 & 14.46 & 3.89 & 18.55 & 1.39 & 20.35 & 0.56 & 21.08 & 1.03 & 19.51 & 2.69 \\
\hline $\mathrm{CaO}$ & 0,16 & 0,03 & 0,36 & 0,56 & 0,31 & 0,47 & 0,16 & 0,03 & 0,24 & 0,02 & $\mathrm{CaO}$ & 18.35 & 0.12 & 20.72 & 0.48 & 20.77 & 0.95 & 21.59 & 0.49 & $\mathrm{CaO}$ & 0.02 & & 1.35 & 2.26 & 0.05 & 0.03 & 0.06 & 0.03 & 0.03 & 0.02 & 0.46 & 0.61 \\
\hline $\mathrm{Na}_{2} \mathrm{O}$ & 0,01 & 0,01 & & & & & & & & & $\mathrm{Na}_{2} \mathrm{O}$ & 1.70 & 0.03 & 0.94 & 0.18 & 0.92 & 0.12 & 0.82 & 0.22 & $\mathrm{Na}_{2} \mathrm{O}$ & 0.00 & 0.00 & 1.41 & 2.00 & 0.01 & & 0.01 & 0.01 & 0.01 & 0.01 & 0.04 & 0.05 \\
\hline $\mathrm{K}_{2} \mathrm{O}$ & & & & & & & & & & & $\mathbf{K}_{2} \mathbf{O}$ & 0.00 & 0.00 & 0.00 & 0.01 & n.d. & 0.01 & n.d. & 0.02 & $\mathbf{K}_{2} \mathbf{O}$ & 0.02 & & 0.43 & 0.61 & 0.00 & 0.00 & 0.03 & & n.d. & & 0.01 & 0.01 \\
\hline $\mathrm{V}_{2} \mathrm{O}_{3}$ & & & & & & & & & & & $\mathbf{V}_{2} \mathbf{O}_{3}$ & 0.00 & 0.00 & 0.00 & 0.00 & 0.00 & 0.00 & 0.00 & 0.00 & $\mathrm{~V}_{2} \mathrm{O}_{3}$ & 0.10 & 0.06 & 0.16 & 0.00 & 0.15 & 0.01 & 0.20 & 0.02 & 0.13 & 0.06 & 0.16 & 0.08 \\
\hline Total & 99,91 & 0,54 & 99,76 & 0,82 & 99,08 & 2,34 & 100,34 & 1,17 & 99,98 & 0,55 & Total & 99.50 & 0.03 & 99.38 & 0.35 & 98.88 & 0.79 & 98.56 & 0.91 & Total & 99.82 & 0.15 & 97.66 & 4.24 & 98.15 & 0.61 & 99.15 & 0.82 & 99.01 & 0.51 & 99.26 & 0.98 \\
\hline mg\# & 90,68 & 0,57 & 91,84 & 0,31 & 91,18 & 0,66 & 91,48 & 0,30 & 92,44 & 0,25 & mg\# & 85.60 & 0.06 & 87.25 & 1.34 & 87.26 & 0.48 & 89.76 & 0.82 & mg\# & 76.67 & 2.41 & 67.45 & 1.51 & 69.42 & 2.54 & 76.89 & 1.42 & 77.92 & 2.06 & 75.35 & 6.48 \\
\hline & & & & & & & & & & & & & & & & & & & & cr\# & 11.45 & 2.27 & 36.94 & 13.53 & 30.86 & 6.01 & 16.64 & 5.59 & 13.25 & 3.29 & 20.59 & 10.45 \\
\hline
\end{tabular}

\begin{tabular}{|c|c|c|c|c|c|c|c|c|}
\hline \multicolumn{9}{|l|}{ Amp } \\
\hline Sample & SZG30 & & FT12 & & FT08P & & $\underset{\text { A }}{\operatorname{MSZK130}}$ & \\
\hline$n=$ & 7 & $\sigma$ & 1 & $\sigma$ & 9 & $\sigma$ & 11 & $\sigma$ \\
\hline $\mathrm{SiO}_{2}$ & 42,08 & 0,79 & 42,86 & & 43,30 & 0,49 & 44,40 & 0,50 \\
\hline $\mathrm{TiO}_{2}$ & 2,56 & 0,07 & 1,52 & - & 0,68 & 0,04 & 0,32 & 0,03 \\
\hline $\mathrm{Al}_{2} \mathrm{O}_{3}$ & 15,13 & 0,14 & 15,13 & - & 14,70 & 0,12 & 13,24 & 0,14 \\
\hline $\mathrm{Cr}_{2} \mathrm{O}_{3}$ & 1,14 & 0,04 & 1,00 & & 1,25 & 0,07 & 1,66 & 0,08 \\
\hline $\mathrm{FeO}$ & 4,02 & 0,03 & 4,18 & - & 4,10 & 0,07 & 4,14 & 0,11 \\
\hline MnO & 0,02 & 0,02 & 0,01 & - & 0,01 & 0,02 & 0.00 & 0,02 \\
\hline $\mathrm{NiO}$ & 0,11 & 0,03 & 0,15 & & 0,13 & 0,02 & 0,11 & 0,03 \\
\hline MgO & 17,28 & 0,33 & 17,53 & - & 17,55 & 0,16 & 18,08 & 0,15 \\
\hline $\mathrm{CaO}$ & 10,55 & 0,17 & 10,89 & - & 11,60 & 0,14 & 11,97 & 0,17 \\
\hline $\mathrm{Na}_{2} \mathrm{O}$ & 3,38 & 0,08 & 3,65 & - & 2,70 & 0,04 & 2,14 & 0,04 \\
\hline $\mathrm{K}_{2} \mathrm{O}$ & 0,96 & 0,04 & 0,20 & - & 0,66 & 0,04 & 1,10 & 0,04 \\
\hline $\mathrm{V}_{2} \mathrm{O}_{3}$ & 0,07 & 0,01 & 0,06 & - & 0,06 & 0,01 & 0,08 & 0,00 \\
\hline Total & 97,45 & 0,63 & 97,09 & - & 96,88 & 0,75 & 97,25 & 0,83 \\
\hline mg\# & 88,45 & 0,18 & 88,20 & - & 88,41 & 0,16 & 88,61 & 0,23 \\
\hline
\end{tabular}

Table 3: Secondary minerals from veins and melt pockets (ol, cpx, sp) and amphiboles major element compositions (in wt. \%). 


\begin{tabular}{|c|c|c|c|c|c|c|c|c|c|c|c|c|c|c|c|c|c|c|c|c|}
\hline \multicolumn{21}{|l|}{ Cpx I } \\
\hline Sample & \begin{tabular}{|l|} 
SZB16 \\
\end{tabular} & & $\begin{array}{l}\text { SZB44 } \\
\end{array}$ & & $\begin{array}{l}\text { SZB50 } \\
\end{array}$ & & SZZ51 & & SZB52 & & $\begin{array}{l}\text { SZB66 } \\
\end{array}$ & & SZG14 & & SZG23 & & SZG30 & & SZG44 & \\
\hline $\mathrm{n}=$ & 8 & $\sigma$ & 7 & $\sigma$ & 5 & $\sigma$ & 5 & $\sigma$ & 7 & $\sigma$ & 6 & $\sigma$ & 9 & $\sigma$ & 7 & $\sigma$ & 7 & $\sigma$ & 9 & $\sigma$ \\
\hline Al27 & 39514 & 1903 & 29057 & 266 & 29096 & 346 & 17205 & 290 & 3265 & 687 & 16571 & 437 & 41315 & 1290 & 33800 & 1324 & 36597 & 1011 & 40524 & 1344 \\
\hline Ca44 & 132416 & 6614 & 148566 & 1273 & 147672 & 506 & 149330 & 1381 & 19,7 & 0,4 & 149337 & 3395 & 18,8 & 0,44 & 19,1 & 0,22 & 19,6 & 0,3 & 18,8 & 0,16 \\
\hline Sc45 & 57,2 & 2,54 & 58,5 & 0,82 & 59,2 & 0,39 & 81,81 & 1,12 & 53 & 1,64 & 61,2 & 1,84 & 61,8 & 2,45 & 69,4 & 1,68 & 64,0 & 1,87 & 66 & 1,63 \\
\hline Ti49 & 3486 & 177 & 2236 & 35,5 & 2195,39 & 28,3 & 317 & 2,07 & 1103 & 17,9 & 366 & 10,1 & 4112 & 414 & 2742 & 549 & 3561 & 73,4 & 4224 & 136 \\
\hline v51 & 125 & 9,98 & 158 & 5,36 & 161 & 3,32 & nd & nd & nd & nd & 53,7 & 24,5 & 160 & 4,68 & nd & nd & 142 & 4 & 165 & 10,5 \\
\hline Cr52 & 4862 & 330 & 3153 & 38,8 & 2911 & 71,7 & nd & nd & nd & nd & 3381 & 1143 & 4982 & 182 & nd & nd & 5375 & 185 & 5088 & 140 \\
\hline Cr53 & 5136 & 292 & 3287 & 65,8 & 2991 & 80,9 & 6841 & 358 & 7259 & 195 & 5414 & 164 & 5103 & 183 & 8815 & 274 & 5545 & 183 & 5234 & 134 \\
\hline Mn55 & 771 & 41,9 & 698 & 4,94 & 695 & 11,7 & 643 & 13,6 & 714 & 22,2 & 645 & 17 & 718 & 32,3 & 743 & 14,9 & 691 & 14,7 & 726 & 28,1 \\
\hline Co59 & 25,6 & 1,44 & 23,5 & 0,15 & 22,9 & 0,55 & 23,2 & 0,67 & 26,3 & 0,79 & 24,5 & 0,67 & 23,05 & 1,17 & 22,9 & 0,4 & 22,3 & 0,61 & 22,4 & 0,7 \\
\hline Ni60 & 409 & 23,3 & 367 & 3,37 & 358 & 7,3 & 370 & 11,0 & 433 & 11,6 & 410 & 11,5 & 358 & 17,5 & 366 & 6,14 & 350 & 11,8 & 336 & 8,96 \\
\hline Rb85 & nd & nd & nd & nd & nd & nd & nd & nd & nd & nd & nd & nd & nd & nd & nd & nd & nd & nd & nd & nd \\
\hline Sr88 & 64,3 & 4,55 & nd & nd & 67,75 & 1,16 & 105,96 & 0,78 & 23,12 & 1,12 & 62,4 & 0,98 & 77,01 & 2,9 & 154,64 & 34,11 & 71,2 & 0,95 & nd & nd \\
\hline Y89 & 18,1 & 0,85 & 17,0 & 0,37 & 16,88 & 0,11 & 3,07 & 0,05 & 8,75 & 0,22 & 3,02 & 0,11 & 18,67 & 0,53 & 15,98 & 0,49 & 17,07 & 0,81 & 18,61 & 0,31 \\
\hline $\mathrm{Zr} 90$ & 28,0 & 1,68 & 30 & 0,57 & 29,42 & 0,14 & 9,62 & 0,34 & 9,4 & 0,29 & 8,58 & 0,31 & 33,93 & 1,66 & 35,99 & 2,89 & 27,46 & 1,14 & 34,78 & 1,01 \\
\hline Nb93 & 0,19 & 0,09 & 0,08 & 0,01 & 0,08 & 0,01 & 0,12 & 0,02 & nd & nd & 0,28 & 0,02 & nd & nd & nd & nd & nd & nd & nd & nd \\
\hline Ba135 & nd & nd & nd & nd & nd & nd & nd & nd & nd & nd & nd & nd & nd & nd & nd & nd & nd & nd & nd & nd \\
\hline Ba137 & 0,08 & 0,02 & nd & nd & nd & nd & 0,08 & 0,05 & 0,43 & 0,67 & nd & nd & nd & nd & nd & nd & nd & nd & nd & nd \\
\hline La139 & 0,71 & 0,15 & 3 & 0,04 & 3 & 0,03 & 3,43 & 0,04 & 0,94 & 0,03 & 1,16 & 0,05 & 1,3 & 0,43 & 7,44 & 2,37 & 1,33 & 0,03 & 1,28 & 0,22 \\
\hline Ce140 & 2,95 & 0,26 & 9,61 & 0,14 & 9,35 & 0,18 & 5,27 & 0,2 & 2,71 & 0,12 & 2,35 & 0,05 & 4,4 & 1,32 & 20,88 & 6,61 & 4,36 & 0,14 & 4,8 & 0,17 \\
\hline Pr141 & 0,61 & 0,04 & 1,67 & 0,02 & 1,64 & 0,02 & 0,44 & 0,02 & 0,4 & 0,01 & 0,31 & 0,01 & 0,78 & 0,19 & 2,74 & 0,85 & 0,74 & 0,02 & 0,84 & 0,05 \\
\hline Nd146 & 3,96 & 0,24 & 8,25 & 0,65 & 8,41 & 0,08 & 1,43 & 0,04 & 1,97 & 0,04 & 1,38 & 0,04 & 4,66 & 0,82 & 11,92 & 3,36 & 4,25 & 0,1 & 4,89 & 0,13 \\
\hline Sm147 & 1,7 & 0,09 & 2,34 & 0,08 & 2,34 & 0,04 & 0,29 & 0,02 & 0,62 & 0,03 & 0,35 & 0,01 & 1,77 & 0,18 & 2,73 & 0,52 & 1,58 & 0,04 & 1,83 & 0,05 \\
\hline Eu151 & 0,69 & 0,04 & 0,8 & 0,07 & 0,81 & 0,02 & 0,12 & 0,01 & 0,23 & 0,01 & 0,13 & 0,01 & 0,72 & 0,04 & 1 & 0,15 & 0,65 & 0,02 & 0,71 & 0,02 \\
\hline Eu153 & 0,69 & 0,04 & 0,81 & 0,02 & 0,8 & 0,02 & 0,12 & 0 & 0,23 & 0,01 & 0,14 & 0 & 0,72 & 0,05 & 1,01 & 0,15 & 0,66 & 0,02 & 0,71 & 0,02 \\
\hline Gd157 & 2,55 & 0,16 & 2,77 & 0,08 & 2,68 & 0,03 & 0,36 & 0,02 & 0,97 & 0,04 & 0,38 & 0,03 & 2,64 & 0,15 & 3,03 & 0,19 & 2,42 & 0,11 & 2,62 & 0,1 \\
\hline Tb159 & 0,48 & 0,02 & 0,46 & 0,04 & 0,46 & 0,01 & 0,06 & 0 & 0,18 & 0,01 & 0,07 & 0 & 0,48 & 0,02 & 0,49 & 0,02 & 0,43 & 0,02 & 0,47 & 0,01 \\
\hline Dy163 & 3,23 & 0,14 & 3,16 & 0,09 & 3,11 & 0,07 & 0,48 & 0,03 & 1,48 & 0,04 & 0,5 & 0,02 & 3,47 & 0,12 & 3,27 & 0,09 & 3,11 & 0,12 & 3,39 & 0,09 \\
\hline Ho165 & 0,7 & 0,03 & 0,66 & 0,02 & 0,66 & 0,01 & 0,12 & 0 & 0,34 & 0,01 & 0,12 & 0,01 & 0,75 & 0,02 & 0,63 & 0,02 & 0,67 & 0,03 & 0,72 & 0,02 \\
\hline Er166 & 2,03 & 0,11 & 1,92 & 0,04 & 1,88 & 0,03 & 0,4 & 0,01 & 1,04 & 0,02 & 0,39 & 0,01 & 2,15 & 0,06 & 1,7 & 0,05 & 1,92 & 0,08 & 2,09 & 0,04 \\
\hline Tm169 & 0,28 & 0,02 & 0,26 & 0,01 & 0,26 & 0,01 & 0,06 & 0 & 0,16 & 0,01 & 0,06 & 0 & 0,31 & 0,01 & 0,23 & 0,01 & 0,27 & 0,01 & 0,3 & 0,01 \\
\hline Yb172 & 1,81 & 0,09 & 1,74 & 0,07 & 1,71 & 0,04 & 0,48 & 0,03 & 1,07 & 0,03 & 0,44 & 0,03 & 2,07 & 0,04 & 1,51 & 0,06 & 1,79 & 0,1 & 2,01 & 0,06 \\
\hline Lu175 & 0,26 & 0,01 & 0,24 & 0,01 & 0,25 & 0 & 0,08 & 0 & 0,15 & 0,01 & 0,07 & 0 & 0,29 & 0,01 & 0,2 & 0,01 & 0,25 & 0,01 & 0,29 & 0,01 \\
\hline Hf178 & 0,95 & 0,05 & 1,01 & 0,02 & 1,01 & 0,03 & 0,33 & 0,03 & 0,26 & 0,01 & 0,28 & 0,01 & 1,13 & 0,1 & 1,03 & 0,04 & 0,91 & 0,03 & 1,07 & 0,04 \\
\hline Ta181 & nd & nd & nd & nd & 0,01 & 0 & 0,01 & 0 & 0,02 & 0,01 & 0,03 & 0 & 0,03 & 0,01 & 0,01 & 0,01 & 0,02 & 0 & nd & nd \\
\hline Pb208 & 0,05 & 0,01 & nd & nd & 0,3 & 0,01 & 0,37 & 0,02 & nd & nd & 0,65 & 0,03 & nd & nd & 0,28 & 0,08 & 0,09 & 0,02 & nd & nd \\
\hline Th232 & 0,03 & 0,01 & 0,35 & 0,01 & 0,35 & 0,01 & 0,37 & 0,01 & 0,1 & 0,01 & 0,07 & 0,01 & 0,05 & 0,01 & 0,36 & 0,06 & 0,05 & 0 & nd & nd \\
\hline U238 & nd & nd & 0,08 & 0,02 & 0,09 & 0 & 0,08 & 0,01 & 0,04 & 0 & 0,03 & 0 & 0,02 & 0,01 & 0,06 & 0,01 & 0,02 & 0 & nd & nd \\
\hline
\end{tabular}




\begin{tabular}{|c|c|c|c|c|c|c|c|c|c|c|}
\hline \multicolumn{11}{|l|}{ Cpx I } \\
\hline \multirow{2}{*}{$\begin{array}{l}\text { Sample } \\
n=\end{array}$} & \multirow{2}{*}{$\begin{array}{l}\text { FT12 } \\
10\end{array}$} & \multirow[b]{2}{*}{$\sigma$} & \multicolumn{2}{|l|}{ FT01P } & \multicolumn{2}{|l|}{ FT08P } & \multicolumn{2}{|c|}{ MSZK1306A } & \multicolumn{2}{|c|}{ MSZK1308 } \\
\hline & & & 3 & $\sigma$ & 6 & $\sigma$ & 6 & $\sigma$ & 7 & $\sigma$ \\
\hline Al27 & 29735 & 270 & 22038 & 1370 & 18680 & 1451 & 13082 & 518 & 36909 & 677 \\
\hline Ca44 & 152067 & 1114 & 137103 & 1155 & 161737 & 12647 & 168074 & 596 & 139918 & 2328 \\
\hline Sc45 & 61,3 & 1,15 & 56,4 & 2,18 & 53,1 & 3,59 & 66,3 & 1,26 & 63,5 & 1,27 \\
\hline Ti49 & 2016 & 48,3 & 1348 & 266 & 842 & 74,2 & 459 & 11,7 & 3130 & 51,1 \\
\hline v51 & 179 & 4,91 & nd & nd & 122 & 9,9 & 149 & 3,84 & 148 & 4,94 \\
\hline Cr52 & 3658 & 91,1 & nd & nd & 2982 & 318 & 2541 & 560 & 6530 & 245 \\
\hline Cr53 & 3752 & 90,6 & 9920 & 595 & 3020 & 323 & 2687 & 602 & 6864 & 204 \\
\hline Mn55 & 674 & 5,23 & 688 & 36,0 & 617 & 52 & 601 & 14,4 & 685 & 14,3 \\
\hline Co59 & 22,2 & 0,31 & 26,1 & 0,62 & 21,1 & 1,94 & 22,0 & 0,53 & 23,4 & 0,58 \\
\hline Ni60 & 352 & 4,05 & 413 & 15,6 & 339 & 31,2 & 372 & 10,5 & 376 & 9,58 \\
\hline Rb85 & nd & nd & nd & nd & nd & nd & nd & nd & nd & nd \\
\hline Sr88 & 109 & 3,31 & 88,3 & 35,5 & 136 & 8,27 & 38,4 & 0,95 & 59,8 & 2,29 \\
\hline Y89 & 14,6 & 0,29 & 6,09 & 0,73 & 7,75 & 0,56 & 3,45 & 0,08 & 15,4 & 0,31 \\
\hline Zr90 & 20,6 & 0,52 & 16,2 & 6,29 & 11,0 & 1,08 & 6,49 & 0,35 & 23,1 & 0,42 \\
\hline Nb93 & 0,21 & 0,03 & 1,44 & 0,32 & 0,09 & 0,01 & 0,12 & 0,03 & 0,38 & 0,01 \\
\hline Ba135 & nd & nd & nd & nd & nd & nd & nd & nd & nd & nd \\
\hline Ba137 & nd & nd & 0,1 & 0,03 & 0,1 & 0,04 & 0,04 & 0,01 & nd & nd \\
\hline La139 & 13,7 & 0,41 & 3,41 & 1,09 & 38,5 & 2,93 & 2,83 & 0,06 & 0,98 & 0,03 \\
\hline Ce140 & 36,0 & 1,13 & 8,09 & 2,79 & 45,4 & 3,44 & 6,62 & 0,35 & 3,17 & 0,07 \\
\hline Pr141 & 4,27 & 0,15 & 1,07 & 0,39 & 3,68 & 0,27 & 0,77 & 0,07 & 0,55 & 0,02 \\
\hline Nd146 & 15,9 & 0,5 & 5,14 & 1,83 & 11,5 & 0,93 & 2,94 & 0,24 & 3,38 & 0,1 \\
\hline Sm147 & 2,71 & 0,07 & 1,29 & 0,38 & 1,66 & 0,11 & 0,51 & 0,05 & 1,36 & 0,08 \\
\hline Eu151 & 0,8 & 0,03 & 0,46 & 0,12 & 0,44 & 0,04 & 0,14 & 0,01 & 0,53 & 0,02 \\
\hline Eu153 & 0,78 & 0,02 & 0,46 & 0,12 & 0,43 & 0,04 & 0,15 & 0,02 & 0,52 & 0,01 \\
\hline Gd157 & 2,53 & 0,1 & 1,38 & 0,36 & 1,37 & 0,11 & 0,45 & 0,03 & 2,06 & 0,07 \\
\hline Tb159 & 0,39 & 0,02 & 0,21 & 0,04 & 0,21 & 0,01 & 0,07 & 0,01 & 0,37 & 0,01 \\
\hline Dy163 & 2,62 & 0,11 & 1,28 & 0,18 & 1,37 & 0,09 & 0,57 & 0,04 & 2,73 & 0,1 \\
\hline Ho165 & 0,55 & 0,02 & 0,24 & 0,03 & 0,29 & 0,02 & 0,13 & 0,01 & 0,58 & 0,02 \\
\hline Er166 & 1,55 & 0,05 & 0,63 & 0,07 & 0,84 & 0,05 & 0,42 & 0,02 & 1,66 & 0,05 \\
\hline Tm169 & 0,23 & 0,01 & 0,08 & 0,01 & 0,13 & 0,01 & 0,07 & 0 & 0,23 & 0,01 \\
\hline Yb172 & 1,47 & 0,06 & 0,51 & 0,03 & 0,86 & 0,06 & 0,51 & 0,02 & 1,49 & 0,06 \\
\hline Lu175 & 0,21 & 0,01 & 0,07 & 0 & 0,13 & 0,01 & 0,07 & 0 & 0,21 & 0,01 \\
\hline Hf178 & 0,77 & 0,04 & 0,49 & 0,12 & 0,23 & 0,03 & 0,19 & 0,02 & 0,79 & 0,03 \\
\hline Ta181 & 0,02 & 0 & 0,16 & 0,07 & 0,02 & 0 & 0,02 & 0 & 0,03 & 0 \\
\hline Pb208 & 1,58 & 0,08 & 0,06 & 0,02 & 5,42 & 0,57 & 0,17 & 0,02 & nd & nd \\
\hline Th232 & 2,53 & 0,18 & 0,32 & 0,08 & 6,71 & 0,76 & 0,21 & 0,02 & 0,03 & 0,01 \\
\hline U238 & 0,36 & 0,03 & 0,07 & 0,01 & 1,77 & 0,18 & 0,04 & 0,01 & nd & $\mathrm{Nd}$ \\
\hline
\end{tabular}

\begin{tabular}{|c|c|c|c|c|}
\hline Amphibo & & & & \\
\hline Sample & FT08P & & MSZK1306 & \\
\hline $\mathrm{N}=$ & 5 & $\sigma$ & 6 & $\sigma$ \\
\hline $\begin{array}{l}\text { Al27 } \\
\text { P31 }\end{array}$ & $\begin{array}{c}68264 \\
n d\end{array}$ & $\begin{array}{l}785 \\
\text { nd }\end{array}$ & $\begin{array}{c}59474 \\
\text { nd }\end{array}$ & $\begin{array}{c}965 \\
\text { nd }\end{array}$ \\
\hline Ca44 & 71470 & 0 & 71470 & 0 \\
\hline Sc45 & 58,3 & 1,27 & 82,6 & 1,88 \\
\hline Ti49 & 3607 & 83,2 & 1826 & 28,3 \\
\hline v51 & 193 & 17,8 & 102 & 52,18 \\
\hline Cr52 & 6859 & 427 & 4545 & 1802 \\
\hline Cr53 & 7324 & 195 & 9683 & 236 \\
\hline Mn55 & 370 & 8,53 & 323 & 3,03 \\
\hline Co59 & 34,2 & 1,29 & 32,7 & 0,42 \\
\hline Ni60 & 759 & 25,6 & 781 & 13,9 \\
\hline Rb85 & 16,7 & 1,53 & 12,3 & 1,22 \\
\hline Sr88 & 492 & 18,8 & 112 & 2,82 \\
\hline Y89 & 16,1 & 0,35 & 7,97 & 0,27 \\
\hline Zr9o & 20,3 & 0,45 & 15,6 & 0,19 \\
\hline Nb93 & 10,7 & 0,33 & 14,1 & 0,21 \\
\hline Ba135 & 912 & 44,0 & 235 & 24,4 \\
\hline Ba137 & 915 & 43,3 & 234 & 25,4 \\
\hline La139 & 72,1 & 2,44 & 6,69 & 0,21 \\
\hline Ce140 & 83,4 & 3,17 & 16,0 & 0,26 \\
\hline Pr141 & 6,68 & 0,27 & 1,89 & 0,09 \\
\hline Pr141 & nd & nd & nd & nd \\
\hline Nd146 & 20,8 & 0,63 & 7,45 & 0,52 \\
\hline Sm147 & 3,14 & 0,15 & 1,21 & 0,08 \\
\hline Eu151 & 0,88 & 0,05 & 0,35 & 0,01 \\
\hline Eu153 & 0,85 & 0,02 & 0,34 & 0,01 \\
\hline Gd157 & 2,77 & 0,11 & 1,08 & 0,05 \\
\hline Tb159 & 0,4 & 0,01 & 0,16 & 0 \\
\hline Dy163 & 2,77 & 0,09 & 1,25 & 0,05 \\
\hline Ho165 & 0,59 & 0,03 & 0,31 & 0,01 \\
\hline Er166 & 1,75 & 0,02 & 0,96 & 0,04 \\
\hline Tm169 & 0,25 & 0,01 & 0,15 & 0,01 \\
\hline Yb172 & 1,64 & 0,07 & 1,08 & 0,04 \\
\hline Lu175 & 0,25 & 0,01 & 0,16 & 0,01 \\
\hline Hf178 & 0,41 & 0,03 & 0,42 & 0,02 \\
\hline Ta181 & 0,34 & 0,02 & 0,77 & 0,04 \\
\hline Pb208 & 28,4 & 1,25 & 0,61 & 0,02 \\
\hline Th232 & 14,5 & 0,5 & 0,62 & 0,04 \\
\hline U238 & 3,16 & 0,13 & 0,1 & 0,01 \\
\hline
\end{tabular}

Table 4: Primary Cpx and amphiboles trace element compositions (in ppm). 
Click here to download Table: Table 5.doc

\begin{tabular}{|c|c|c|c|c|c|c|c|c|c|c|c|c|c|c|c|c|c|c|c|c|c|}
\hline \multicolumn{22}{|l|}{ Glass } \\
\hline & SZB16 & & & \multicolumn{3}{|l|}{ SZB44 } & \multicolumn{3}{|l|}{ SZB50 } & \multicolumn{2}{|l|}{ SZB51 } & \multicolumn{3}{|c|}{ SZB51 } & \multicolumn{3}{|c|}{ SZB52 } & \multicolumn{3}{|c|}{ SZB66 } & \multirow[b]{3}{*}{ Max } \\
\hline & \multicolumn{3}{|l|}{ Vein } & MP & & & MP & & & MP & & & Vein & & & Vein & & & Vein & & \\
\hline & 8 & Min & Max & 10 & Min & Max & 4 & Min & Max & 3 & Min & Max & 4 & Min & Max & 6 & Min & Max & 6 & Min & \\
\hline $\mathrm{SiO}_{2}$ & 56,55 & 55,82 & 57,60 & 54,16 & 53,39 & 54,81 & 55,43 & 55,28 & 55,87 & 56,63 & 56,63 & 56,63 & 61,89 & 60,53 & 62,71 & 57,87 & 56,52 & 59,02 & 60,86 & 59,55 & 61,50 \\
\hline $\mathrm{TiO}_{2}$ & 1,57 & 1,46 & 1,69 & 1,72 & 1,67 & 1,84 & 1,71 & 1,62 & 1,73 & 0,43 & 0,43 & 0,43 & 0,14 & 0,07 & 0,19 & 0,75 & 0,52 & 0,99 & 1,29 & 1,21 & 1,41 \\
\hline $\mathrm{Al}_{2} \mathrm{O}_{3}$ & 19,15 & 18,82 & 19,51 & 20,79 & 20,20 & 21,28 & 20,60 & 20,52 & 20,86 & 22,55 & 22,55 & 22,55 & 18,57 & 18,54 & 18,66 & 20,37 & 19,96 & 20,95 & 18,04 & 18,02 & 18,11 \\
\hline FeO & 3,85 & 3,28 & 4,34 & 3,99 & 3,69 & 4,49 & 3,82 & 3,67 & 3,88 & 2,89 & 2,89 & 2,89 & 2,88 & 2,80 & 3,01 & 3,11 & 2,97 & 3,28 & 3,06 & 2,99 & 3,14 \\
\hline MnO & 0,06 & 0,01 & 0,09 & 0,08 & 0,05 & 0,11 & 0,06 & 0,05 & 0,06 & 0,07 & 0,07 & 0,07 & 0,04 & 0,00 & 0,07 & 0,07 & 0,01 & 0,13 & 0,08 & 0,05 & 0,12 \\
\hline $\mathrm{MgO}$ & 3,57 & 3,49 & 3,73 & 4,59 & 4,29 & 4,86 & 4,33 & 4,20 & 4,38 & 3,23 & 3,23 & 3,23 & 2,56 & 2,46 & 2,70 & 3,37 & 3,16 & 3,49 & 3,08 & 2,91 & 3,30 \\
\hline $\mathrm{CaO}$ & 7,88 & 7,47 & 8,25 & 9,89 & 9,55 & 10,08 & 9,19 & 8,34 & 9,47 & 7,66 & 7,66 & 7,66 & 4,82 & 4,50 & 5,45 & 7,79 & 7,64 & 7,90 & 5,88 & 5,70 & 6,12 \\
\hline $\mathrm{Na}_{2} \mathrm{O}$ & 4,12 & 3,97 & 4,21 & 4,05 & 4,03 & 4,10 & 4,32 & 4,16 & 4,38 & 5,50 & 5,50 & 5,50 & 5,58 & 5,48 & 5,66 & 4,13 & 3,92 & 4,27 & 4,70 & 4,42 & 4,82 \\
\hline $\mathbf{K}_{2} \mathrm{O}$ & 1,71 & 1,59 & 1,84 & 0,08 & 0,05 & 0,09 & 0,05 & 0,04 & 0,08 & 1,76 & 1,76 & 1,76 & 2,33 & 2,19 & 2,42 & 1,96 & 1,87 & 2,15 & 2,81 & 2,71 & 2,94 \\
\hline $\mathbf{P}_{2} \mathbf{O}_{5}$ & 0,45 & 0,38 & 0,52 & 0,05 & 0,01 & 0,07 & 0,01 & 0,01 & 0,03 & 0,24 & 0,24 & 0,24 & 1,10 & 0,98 & 1,15 & 0,50 & 0,48 & 0,54 & 0,94 & 0,92 & 0,94 \\
\hline Total & 99,04 & 98,39 & 99,39 & 99,54 & 98,87 & 100,24 & 99,65 & 98,98 & 99,87 & 101,07 & 101,07 & 101,07 & 100,14 & 99,38 & 100,99 & 100,05 & 98,53 & 101,41 & 100,91 & 99,83 & 101,53 \\
\hline Mg\# & 62,35 & 59,58 & 65,48 & 67,25 & 64,57 & 68,71 & 66,89 & 66,81 & 67,12 & 66,58 & 66,58 & 66,58 & 61,33 & 60,57 & 62,69 & 65,83 & 64,99 & 66,39 & 64,14 & 63,13 & 65,98 \\
\hline
\end{tabular}

\begin{tabular}{|c|c|c|c|c|c|c|c|c|c|c|c|c|c|c|c|c|c|}
\hline & \multirow{3}{*}{$\begin{array}{c}\text { SZG14 } \\
\text { Vein } \\
3\end{array}$} & \multicolumn{3}{|c|}{ SZG23 } & \multicolumn{3}{|c|}{ SZG44 } & \multicolumn{3}{|c|}{ FT12 } & \multicolumn{3}{|c|}{ FT01P } & \multicolumn{3}{|c|}{ FT08P } & \multirow[b]{3}{*}{ Max } \\
\hline & & SMI & MP & & & MP & & & MP & & & Vein & & & MP & & \\
\hline & & Min & 6 & Min & Max & 8 & Min & Max & 9 & Min & Max & 8 & Min & Max & 6 & Min & \\
\hline $\mathrm{SiO}_{2}$ & 54,97 & 54,20 & 56,33 & 55,41 & 57,17 & 51,71 & 50,81 & 51,93 & 54,83 & 53,73 & 55,83 & 57,79 & 56,18 & 59,58 & 52,89 & 51,35 & 56,17 \\
\hline $\mathrm{TiO}_{2}$ & 1,74 & 1,74 & 1,52 & 1,27 & 1,88 & 2,72 & 2,45 & 3,21 & 1,64 & 1,60 & 1,69 & 1,76 & 1,58 & 2,03 & 0,80 & 0,72 & 0,93 \\
\hline $\mathrm{Al}_{2} \mathrm{O}_{3}$ & 20,63 & 22,89 & 20,16 & 19,46 & 20,87 & 20,40 & 19,58 & 21,15 & 20,43 & 19,55 & 21,06 & 17,56 & 16,99 & 18,37 & 22,90 & 21,62 & 23,75 \\
\hline $\mathrm{FeO}$ & 3,47 & 3,34 & 3,60 & 3,42 & 4,07 & 3,82 & 3,62 & 4,15 & 3,62 & 3,01 & 4,89 & 2,67 & 2,47 & 2,94 & 3,67 & 3,02 & 4,25 \\
\hline MnO & 0,11 & 0,01 & 0,08 & 0,00 & 0,14 & 0,08 & 0,04 & 0,12 & 0,05 & 0,03 & 0,10 & 0,04 & $-0,01$ & 0,08 & 0,09 & 0,06 & 0,11 \\
\hline MgO & 4,21 & 2,32 & 3,88 & 3,15 & 4,39 & 4,76 & 4,51 & 5,00 & 3,61 & 3,37 & 4,13 & 2,54 & 2,40 & 2,66 & 3,19 & 2,83 & 3,41 \\
\hline $\mathrm{CaO}$ & 7,50 & 2,02 & 8,02 & 7,72 & 8,19 & 8,91 & 8,66 & 9,40 & 9,83 & 9,50 & 10,45 & 5,80 & 5,54 & 6,50 & 9,41 & 7,99 & 12,47 \\
\hline $\mathrm{Na}_{2} \mathrm{O}$ & 5,10 & 7,31 & 4,93 & 4,80 & 5,09 & 5,17 & 4,79 & 5,45 & 5,15 & 4,65 & 5,55 & 4,82 & 4,59 & 5,20 & 5,25 & 4,53 & 5,81 \\
\hline $\mathrm{K}_{2} \mathrm{O}$ & 1,85 & 5,26 & 0,90 & 0,57 & 1,19 & 0,63 & 0,40 & 0,77 & 0,26 & 0,21 & 0,33 & 4,55 & 3,18 & 5,87 & 0,95 & 0,34 & 1,38 \\
\hline $\mathbf{P}_{2} \mathbf{O}_{5}$ & 0,22 & 0,12 & 0,08 & 0,04 & 0,12 & 0,05 & 0,04 & 0,06 & 0,05 & 0,00 & 0,09 & 0,48 & 0,45 & 0,54 & 0,09 & 0,06 & 0,11 \\
\hline Total & 99,92 & 99,39 & 99,58 & 99,02 & 100,26 & 98,30 & 97,83 & 98,81 & 99,56 & 99,06 & 100,09 & 98,15 & 97,60 & 98,76 & 99,65 & 98,92 & 100,9 \\
\hline Mg\# & 68,35 & 55,30 & 65,49 & 62,14 & 68,30 & 68,91 & 66,95 & 71,08 & 62,59 & 55,57 & 67,52 & 62,91 & 60,38 & 65,24 & 60,94 & 58,11 & 63,99 \\
\hline
\end{tabular}

Table 5: Major element composition for glass in melt veins, melt pockets (MP) and silicate melt inclusions (SMI) (in wt. \%). 
Click here to download Table: Table 6.doc

\begin{tabular}{|c|c|c|c|c|c|c|c|c|c|c|c|c|c|c|}
\hline Sample & SZB16 & & SZB44 & & SZB50 & & SZB51 & & SZB51 & & SZB52 & & SZB66 & \\
\hline Area & vein & & MP & & MP & & MP & & vein & & vein & & vein & \\
\hline $\mathrm{n}=$ & 8 & $\sigma$ & 10 & $\sigma$ & 4 & $\sigma$ & 3 & $\sigma$ & 4 & $\sigma$ & 6 & $\sigma$ & 6 & $\sigma$ \\
\hline Al27 & 101040,49 & 1801,77 & 109676,54 & 1926,10 & 109303,43 & 872,20 & 119310,66 & 30,55 & 98308,24 & 300,94 & 107799,47 & 1762,47 & 95459,12 & 213,46 \\
\hline P31 & 1919,30 & 221,93 & nd & nd & 198,27 & 38,58 & 484,84 & 331,48 & 5565,36 & 1759,09 & 2104,08 & 114,06 & 4403,98 & 269,55 \\
\hline Ca44 & 55865,74 & 2544,66 & 109509,87 & 89709,17 & 65041,53 & 3400,12 & 294332,43 & 234191,99 & 39333,34 & 8606,68 & 53587,94 & 1822,67 & 40433,12 & 1783,61 \\
\hline Sc45 & 24,68 & 1,62 & 84,03 & 95,15 & 38,72 & 0,51 & 312,72 & 267,09 & 35,82 & 31,15 & 19,66 & 1,58 & 24,96 & 0,85 \\
\hline Ti49 & 10377,10 & 800,97 & 13640,90 & 5207,73 & 11042,95 & 338,57 & 4387,56 & 1514,70 & 1045,92 & 120,49 & 5367,87 & 546,38 & 9828,74 & 331,54 \\
\hline v51 & 183,45 & 17,29 & 370,93 & 217,85 & 213,71 & 13,45 & 428,35 & 289,10 & 112,91 & 45,77 & 110,80 & 3,86 & 159,98 & 4,87 \\
\hline Cr52 & 157,71 & 81,26 & 4547,71 & 8431,73 & 117,29 & 87,04 & 16977,90 & 12479,66 & 865,04 & 1392,96 & 251,48 & 300,36 & 103,46 & 16,08 \\
\hline Cr53 & 134,38 & 35,97 & 4783,44 & 8918,07 & 113,78 & 85,97 & 24251,49 & 22983,23 & 873,94 & 1378,29 & 262,08 & 324,38 & 107,17 & 17,17 \\
\hline Mn55 & 656,53 & 67,49 & 715,39 & 216,35 & 741,21 & 266,20 & 958,82 & 484,17 & 5717,65 & 9279,33 & 577,32 & 230,70 & 469,73 & 41,04 \\
\hline Co59 & 19,54 & 5,99 & 22,35 & 10,31 & 31,32 & 28,92 & 45,81 & 26,43 & 791,75 & 1347,95 & 25,33 & 28,65 & 10,09 & 2,06 \\
\hline Ni60 & 154,12 & 106,84 & 206,29 & 280,27 & 366,49 & 561,08 & 727,31 & 679,09 & 2172,06 & 625,64 & 297,97 & 570,17 & 43,75 & 34,36 \\
\hline Rb85 & 39,89 & 3,28 & nd & nd & 1,05 & 0,28 & 17,96 & 14,61 & 80,87 & 15,84 & 44,47 & 3,00 & 69,94 & 5,60 \\
\hline Sr88 & 557,77 & 29,91 & 205,35 & 74,44 & 237,71 & 9,28 & 486,64 & 183,18 & 1034,42 & 21,91 & 541,32 & 11,74 & 866,23 & 57,64 \\
\hline Y89 & 16,46 & 0,80 & 34,62 & 22,17 & 22,69 & 1,15 & 13,69 & 6,61 & 8,08 & 0,75 & 12,33 & 0,27 & 18,58 & 0,75 \\
\hline Zr90 & 139,74 & 11,47 & 35,61 & 3,29 & 34,49 & 2,29 & 71,45 & 15,15 & 378,02 & 21,36 & 134,38 & 3,21 & 259,74 & 14,04 \\
\hline Nb93 & 51,62 & 3,62 & 5,14 & 2,45 & 6,74 & 0,63 & 23,33 & 17,39 & 92,80 & 4,52 & 51,77 & 1,06 & 89,18 & 3,26 \\
\hline Cs133 & 0,49 & 0,06 & nd & nd & 0,05 & 0,01 & nd & nd & 1,99 & 0,33 & 0,59 & 0,05 & 0,99 & 0,10 \\
\hline Ba135 & 524,37 & 29,69 & 95,32 & 76,02 & 124,99 & 71,45 & 209,99 & 167,51 & 791,48 & 48,44 & 635,20 & 36,62 & 833,22 & 20,00 \\
\hline Ba137 & 526,16 & 29,32 & 95,66 & 76,93 & 124,30 & 69,88 & 211,34 & 166,13 & 791,05 & 25,30 & 632,61 & 34,98 & 830,98 & 15,27 \\
\hline La139 & 27,98 & 2,52 & 3,81 & 1,18 & 4,72 & 0,46 & 16,68 & 7,14 & 72,55 & 4,02 & 30,41 & 0,74 & 58,58 & 3,86 \\
\hline Ce140 & 53,10 & 4,52 & 12,46 & 2,00 & 12,83 & 0,42 & 27,71 & 6,85 & 112,40 & 4,12 & 54,64 & 1,11 & 100,46 & 2,32 \\
\hline Pr141 & 5,84 & 0,52 & 2,24 & 0,27 & 2,13 & 0,05 & 2,57 & 0,16 & 9,17 & 0,54 & 5,64 & 0,14 & 11,07 & 0,79 \\
\hline Nd146 & 22,58 & 2,51 & 12,41 & 3,26 & 11,33 & 0,30 & 8,80 & 1,18 & 25,30 & 4,03 & 20,64 & 0,99 & 39,95 & 2,40 \\
\hline Sm147 & 4,08 & 0,35 & 3,89 & 1,87 & 2,79 & 0,14 & 1,57 & 0,44 & 3,06 & 0,69 & 3,23 & 0,28 & 6,56 & 0,38 \\
\hline Eu151 & 1,34 & 0,08 & 1,39 & 0,71 & 0,99 & 0,10 & 0,60 & 0,15 & 0,89 & 0,30 & 0,99 & 0,10 & 1,97 & 0,12 \\
\hline Eu153 & 1,33 & 0,13 & 1,36 & 0,68 & 1,05 & 0,07 & 0,59 & 0,18 & 0,87 & 0,16 & 0,99 & 0,09 & 2,00 & 0,13 \\
\hline Gd157 & 3,73 & 0,40 & 5,11 & 3,14 & 3,26 & 0,23 & 1,78 & 0,73 & nd & nd & 2,67 & 0,22 & 4,99 & 0,29 \\
\hline Tb159 & 0,53 & 0,04 & 0,87 & 0,58 & 0,59 & 0,04 & 0,30 & 0,13 & nd & nd & 0,34 & 0,04 & 0,66 & 0,03 \\
\hline Dy163 & 3,28 & 0,24 & 6,41 & 4,25 & 4,01 & 0,20 & 2,13 & 0,96 & nd & nd & 2,26 & 0,12 & 3,74 & 0,27 \\
\hline Ho165 & 0,62 & 0,04 & 1,32 & 0,86 & 0,83 & 0,09 & 0,52 & 0,25 & 0,30 & 0,09 & 0,44 & 0,03 & 0,69 & 0,04 \\
\hline Er166 & 1,72 & 0,11 & 3,84 & 2,44 & 2,50 & 0,19 & 1,57 & 0,77 & 0,78 & 0,12 & 1,32 & 0,09 & 1,87 & 0,13 \\
\hline Tm169 & 0,25 & 0,02 & 0,55 & 0,35 & 0,35 & 0,02 & 0,26 & 0,14 & 0,16 & 0,09 & 0,18 & 0,02 & 0,26 & 0,02 \\
\hline Yb172 & 1,71 & 0,13 & 3,61 & 2,17 & 2,43 & 0,13 & 1,99 & 0,87 & nd & nd & 1,32 & 0,06 & 1,75 & 0,13 \\
\hline Lu175 & 0,25 & 0,02 & 0,49 & 0,25 & 0,36 & 0,01 & 0,29 & 0,12 & 0,18 & 0,07 & 0,19 & 0,01 & 0,25 & 0,01 \\
\hline Hf178 & 3,01 & 0,31 & 1,21 & 0,38 & 0,98 & 0,04 & 1,93 & 0,35 & 5,40 & 1,08 & 2,65 & 0,06 & 5,05 & 0,38 \\
\hline Ta181 & 3,03 & 0,29 & 0,22 & 0,09 & 0,24 & 0,03 & 1,19 & 0,80 & 6,08 & 0,47 & 3,03 & 0,17 & 5,39 & 0,27 \\
\hline Pb208 & 2,99 & 0,75 & nd & nd & 1,26 & 0,13 & 1,05 & 0,83 & nd & nd & 1,31 & 0,14 & 6,45 & 0,49 \\
\hline Th232 & 3,77 & 0,45 & 0,37 & 0,17 & 0,47 & 0,03 & 2,31 & 1,69 & 16,68 & 2,46 & 4,39 & 0,23 & 8,94 & 0,53 \\
\hline U238 & 1,15 & 0,15 & nd & nd & 0,14 & 0,03 & 0,58 & 0,50 & 5,12 & 0,54 & 1,32 & 0,06 & 2,59 & 0,17 \\
\hline
\end{tabular}




\begin{tabular}{|c|c|c|c|c|c|c|c|c|c|c|c|c|c|c|}
\hline Sample & SZG14 & & SZG14 & & SZG23 & & SZG44 & & FT12 & & FT01P & & FT08P & \\
\hline Area & vein & & SMI & & MP & & MP & & MP & & vein & & MP & \\
\hline $\mathrm{n}=$ & 1 & $\sigma$ & 2 & $\sigma$ & 6 & $\sigma$ & 8 & $\sigma$ & 9 & $\sigma$ & 8 & $\sigma$ & 6 & $\sigma$ \\
\hline A127 & 109184,34 & - & 120748,48 & 561,36 & 106873,28 & 4107,02 & 92149,11 & 27353,80 & 96488,23 & 28673,88 & 92956,22 & 2433,56 & 109978,23 & 26805,35 \\
\hline P31 & 1325,29 & - & 695,06 & 116,52 & 395,80 & 137,63 & 228,64 & 74,04 & nd & nd & nd & nd & nd & nd \\
\hline Ca44 & 48857,56 & - & 25493,42 & 347,92 & 55263,25 & 3220,70 & 50025,66 & 16068,89 & 51124,42 & 15685,12 & 39010,05 & 6080,18 & 87336,26 & 34620,34 \\
\hline Sc45 & 17,60 & - & 16,16 & 0,88 & 35,98 & 5,04 & 24,81 & 9,24 & 28,15 & 8,78 & 16,40 & 2,21 & 48,69 & 53,13 \\
\hline Ti49 & 11032,17 & - & 10232,71 & 2984,16 & 10372,61 & 748,18 & 15903,28 & 5672,20 & 9276,16 & 2734,51 & 12077,85 & 1369,54 & 5420,33 & 396,15 \\
\hline v51 & 108,41 & - & 106,48 & 2,80 & 247,47 & 60,32 & 228,88 & 84,38 & 231,67 & 74,98 & 159,65 & 16,94 & 311,34 & 111,38 \\
\hline Cr52 & 69,51 & - & 251,93 & 180,20 & 3351,20 & 5110,57 & 87,50 & 32,26 & 775,32 & 1873,72 & 70,50 & 17,10 & 2023,04 & 3415,28 \\
\hline Cr53 & 85,82 & - & 270,75 & 200,30 & 3549,59 & 5406,26 & 84,03 & 33,18 & 796,64 & 1925,38 & 73,07 & 16,51 & 2896,19 & 5262,64 \\
\hline Mn55 & 531,03 & - & 446,90 & 6,08 & 973,95 & 984,09 & 496,40 & 157,47 & 536,41 & 139,93 & 375,15 & 66,66 & 530,91 & 157,25 \\
\hline Co59 & 12,84 & - & 17,12 & 2,41 & 69,37 & 125,36 & 12,38 & 4,18 & 33,77 & 36,52 & 11,34 & 4,36 & 24,84 & 24,18 \\
\hline Ni60 & 37,19 & - & 53,88 & 14,28 & 1000,93 & 2196,28 & 39,20 & 18,03 & 712,91 & 1544,87 & 82,33 & 70,76 & 318,39 & 470,67 \\
\hline Rb85 & 26,33 & - & 35,87 & 6,05 & 6,28 & 1,99 & 4,52 & 2,06 & 5,56 & 1,48 & 63,00 & 4,46 & 18,90 & 8,82 \\
\hline Sr88 & 485,15 & - & 570,38 & 128,38 & 609,64 & 112,98 & 278,51 & 77,77 & 364,70 & 108,65 & 601,18 & 81,48 & 1067,74 & 455,20 \\
\hline Y89 & 15,51 & - & 11,04 & 0,31 & 18,52 & 2,94 & 18,76 & 6,13 & 18,83 & 5,68 & 13,46 & 1,61 & 22,92 & 2,97 \\
\hline Zr90 & 99,41 & - & 111,08 & 5,51 & 69,92 & 22,61 & 40,34 & 12,20 & 25,84 & 7,49 & 153,22 & 11,02 & 34,31 & 5,89 \\
\hline Nb93 & 45,24 & - & 54,40 & 9,67 & 23,89 & 9,47 & 11,24 & 3,96 & 23,33 & 6,92 & 59,35 & 6,18 & 24,64 & 10,91 \\
\hline Cs133 & 0,27 & - & 0,25 & 0,06 & 0,11 & 0,06 & 0,03 & 0,02 & nd & nd & nd & nd & nd & nd \\
\hline Ba135 & 380,70 & - & 414,13 & 117,80 & 187,31 & 39,59 & 60,52 & 34,04 & 322,11 & 96,39 & 603,80 & 30,84 & 2696,51 & 1232,56 \\
\hline Ba137 & 388,04 & - & 434,17 & 137,19 & 188,01 & 37,66 & 61,45 & 34,23 & 321,29 & 96,49 & 604,99 & 35,11 & 2691,62 & 1232,25 \\
\hline La139 & 9,37 & - & 6,71 & 1,56 & 17,56 & 6,21 & 2,32 & 0,70 & 21,52 & 6,47 & 33,15 & 4,81 & 151,07 & 58,82 \\
\hline Ce140 & 15,95 & - & 14,12 & 3,26 & 47,19 & 15,60 & 7,41 & 2,19 & 53,38 & 15,90 & 59,45 & 8,17 & 163,69 & 51,63 \\
\hline Pr141 & 1,67 & - & 1,36 & 0,09 & 5,68 & 1,47 & 1,16 & 0,35 & 6,11 & 1,85 & 6,44 & 0,78 & 12,21 & 3,13 \\
\hline Nd146 & 6,78 & - & 5,90 & 0,37 & 23,83 & 6,72 & 6,28 & 1,92 & 22,41 & 6,82 & 24,73 & 3,38 & 35,98 & 5,73 \\
\hline Sm147 & 1,81 & - & 1,57 & 0,13 & 4,60 & 1,32 & 2,02 & 0,66 & 3,58 & 1,09 & 4,27 & 0,79 & 4,72 & 0,35 \\
\hline Eu151 & 0,68 & - & 0,66 & 0,22 & 1,54 & 0,39 & 0,79 & 0,26 & 1,07 & 0,33 & 1,48 & 0,37 & 1,38 & 0,12 \\
\hline Eu153 & 0,78 & - & 0,63 & 0,16 & 1,58 & 0,45 & 0,78 & 0,25 & 1,06 & 0,32 & 1,53 & 0,22 & 1,40 & 0,13 \\
\hline Gd157 & 2,00 & - & 2,24 & 0,26 & 4,34 & 1,02 & 2,73 & 0,93 & 3,17 & 0,98 & 3,55 & 0,74 & 3,86 & 0,71 \\
\hline Tb159 & 0,40 & - & 0,33 & 0,16 & 0,58 & 0,14 & 0,46 & 0,14 & 0,48 & 0,15 & 0,50 & 0,08 & 0,58 & 0,10 \\
\hline Dy163 & 2,92 & - & 1,88 & 0,09 & 3,67 & 0,77 & 3,25 & 1,08 & 3,26 & 1,01 & 2,91 & 0,37 & 3,88 & 0,88 \\
\hline Ho165 & 0,57 & - & 0,44 & 0,04 & 0,68 & 0,11 & 0,70 & 0,23 & 0,69 & 0,21 & 0,54 & 0,12 & 0,82 & 0,15 \\
\hline Er166 & 1,43 & - & 1,19 & 0,15 & 1,85 & 0,23 & 2,05 & 0,65 & 2,01 & 0,61 & 1,33 & 0,16 & 2,54 & 0,38 \\
\hline Tm169 & 0,16 & - & 0,20 & 0,01 & 0,24 & 0,03 & 0,29 & 0,09 & 0,30 & 0,10 & 0,18 & 0,03 & 0,39 & 0,07 \\
\hline Yb172 & 1,51 & - & 0,99 & 0,11 & 1,60 & 0,26 & 2,01 & 0,66 & 2,14 & 0,67 & 1,18 & 0,23 & 2,72 & 0,28 \\
\hline Lu175 & 0,29 & - & 0,16 & 0,04 & 0,22 & 0,04 & 0,29 & 0,09 & 0,30 & 0,09 & 0,17 & 0,04 & 0,38 & 0,07 \\
\hline Hf178 & 2,11 & - & 2,25 & 0,31 & 1,23 & 0,33 & 1,01 & 0,33 & 0,83 & 0,25 & 3,52 & 0,36 & 0,61 & 0,10 \\
\hline Ta181 & 2,05 & - & 1,94 & 0,54 & 0,56 & 0,37 & 0,54 & 0,19 & 0,58 & 0,18 & 3,51 & 0,27 & 0,82 & 0,33 \\
\hline Pb208 & 0,69 & - & 1,03 & 0,47 & 5,36 & 1,44 & 0,27 & 0,18 & 12,56 & 3,61 & 6,95 & 2,87 & 57,38 & 27,54 \\
\hline Th232 & 1,55 & - & 0,65 & 0,33 & 0,40 & 0,03 & 0,05 & 0,01 & 4,43 & 1,30 & 4,84 & 0,64 & 32,23 & 14,03 \\
\hline U238 & nd & - & nd & nd & nd & nd & nd & nd & 0,60 & 0,19 & 1,43 & 0,21 & 7,11 & 3,07 \\
\hline
\end{tabular}

Table 6: Trace element compositions for glass in in melt veins (GB), melt pockets (MP) and silicate melt inclusions (SMI) (in ppm). 
Click here to download Table: Table 7.doc

\begin{tabular}{|c|c|c|c|c|c|c|c|c|c|c|c|c|c|c|c|c|c|c|c|c|}
\hline SZB50 & & & & & & & SZG23 & & & & & & & FT12 & & & & & & \\
\hline Modal & $\begin{array}{r}\text { Ol-II } \\
0,13 \\
\end{array}$ & $\begin{array}{c}\text { Cpx-II } \\
0,34 \\
\end{array}$ & $\begin{array}{c}\text { Sp-II } \\
0,17 \\
\end{array}$ & $\begin{array}{c}\text { Glass } \\
0,36 \\
\end{array}$ & $\begin{array}{c}\text { MP } \\
\text { compo }\end{array}$ & SZT1111 & Modal & $\begin{array}{c}\text { Ol-II } \\
0,12 \\
\end{array}$ & $\begin{array}{c}\text { Cpx- } \\
\text { II } \\
0,5 \\
\end{array}$ & $\begin{array}{c}\text { Sp-II } \\
0,13 \\
\end{array}$ & $\begin{array}{c}\text { Glass } \\
0,26 \\
\end{array}$ & $\begin{array}{c}\text { MP } \\
\text { compo }\end{array}$ & FT08P & Modal & $\begin{array}{l}\text { Ol-II } \\
\mathbf{0 , 4 4} \\
\end{array}$ & $\begin{array}{c}\text { Cpx-II } \\
0,19 \\
\end{array}$ & $\begin{array}{c}\text { Sp-II } \\
0,05 \\
\end{array}$ & $\begin{array}{c}\text { Glass } \\
\\
\mathbf{0 , 3 3} \\
\end{array}$ & $\begin{array}{c}\text { MP } \\
\text { compo }\end{array}$ & FT08P \\
\hline $\mathrm{Na}_{2} \mathrm{O}$ & 0,01 & 1,07 & 0,00 & 4,16 & 1,86 & 2,90 & $\mathrm{Na}_{2} \mathrm{O}$ & 0,07 & 1,00 & 0,01 & 4,93 & 1,79 & 2,72 & $\mathrm{Na}_{2} \mathrm{O}$ & 0,01 & 0,77 & 0,01 & 5,15 & 1,85 & 2,72 \\
\hline MgO & 49,09 & 15,65 & 20,81 & 4,20 & 16,75 & 18,07 & MgO & 48,02 & 13,28 & 18,55 & 3,88 & 15,82 & 17,60 & MgO & 49,58 & 14,58 & 21,08 & 3,61 & 26,83 & 17,60 \\
\hline $\mathrm{SiO}_{2}$ & 41,06 & 52,84 & 0,06 & 55,87 & 43,43 & 42,46 & $\mathrm{SiO}_{2}$ & 41,38 & 46,63 & 0,09 & 56,33 & 42,94 & 43,18 & $\mathrm{SiO}_{2}$ & 41,78 & 47,83 & 0,08 & 54,83 & 45,57 & 43,18 \\
\hline $\mathrm{Al}_{2} \mathbf{O}_{3}$ & 0,05 & 5,76 & 56,35 & 20,86 & 19,05 & 15,28 & $\mathbf{A l}_{2} \mathbf{O}_{3}$ & 0,39 & 8,49 & 38,56 & 20,16 & 14,55 & 14,75 & $\mathrm{Al}_{2} \mathbf{O}_{3}$ & 0,06 & 9,32 & 54,34 & 20,43 & 11,26 & 14,75 \\
\hline $\mathbf{K}_{2} \mathrm{O}$ & 0,02 & 0,01 & 0,02 & 0,08 & 0,04 & 0,36 & $\mathrm{~K}_{2} \mathrm{O}$ & 0,04 & 0,01 & 0,00 & 0,90 & 0,24 & 0,63 & $\mathrm{~K}_{2} \mathrm{O}$ & 0,01 & 0,03 & 0,00 & 0,26 & 0,10 & 0,63 \\
\hline $\mathrm{CaO}$ & 0,16 & 21,06 & 0,02 & 8,34 & 10,19 & 11,58 & $\mathrm{CaO}$ & 0,31 & 19,97 & 0,05 & 8,02 & 12,11 & 11,67 & $\mathrm{CaO}$ & 0,16 & 20,05 & 0,03 & 9,83 & 7,13 & 11,67 \\
\hline $\mathrm{TiO}_{2}$ & 0,05 & 0,43 & 0,23 & 3,67 & 1,51 & 1,20 & $\mathrm{TiO}_{2}$ & 0,07 & 1,37 & 0,64 & 3,60 & 1,71 & 0,71 & $\mathrm{TiO}_{2}$ & 0,02 & 1,77 & 0,27 & 3,62 & 1,55 & 0,71 \\
\hline $\mathrm{FeO}$ & 8,99 & 3,20 & 11,28 & 1,62 & 4,76 & 4,09 & $\mathrm{FeO}$ & 8,27 & 2,98 & 14,54 & 1,52 & 4,77 & 4,11 & $\mathrm{FeO}$ & 8,23 & 3,14 & 10,63 & 1,64 & 5,29 & 4,11 \\
\hline $\mathrm{P}_{2} \mathrm{O}_{5}$ & 0,02 & 0,04 & n.d & 0,03 & 0,03 & n.d & $\mathbf{P}_{2} \mathbf{O}_{5}$ & 0,04 & 0,01 & 0,01 & 0,08 & $\mathbf{0 , 0 3}$ & 0,04 & $\mathbf{P}_{2} \mathbf{O}_{5}$ & 0,04 & 0,06 & 0,06 & 0,05 & 0,05 & 0,04 \\
\hline MnO & 0,12 & 0,04 & n.d & 0,05 & 0,05 & 0,06 & MnO & 0,12 & n.d & 0,00 & 0,08 & 0,04 & 0,01 & MnO & 0,13 & 0,04 & 0,00 & 0,05 & 0,08 & 0,01 \\
\hline $\mathrm{Cr}_{2} \mathrm{O}_{3}$ & 0,08 & n.d & 10,85 & n.d & 1,85 & n.d & $\mathrm{Cr}_{2} \mathrm{O}_{3}$ & 0,11 & 3,80 & 25,60 & n.d & 5,24 & 1,29 & $\mathrm{Cr}_{2} \mathrm{O}_{3}$ & n.d & 2,52 & 12,31 & n.d & 1,09 & 1,29 \\
\hline Total & 99,91 & 100,85 & 99,82 & 98,98 & 99,88 & 97,55 & Total & 99,08 & 97,58 & 98,15 & 99,58 & 99,33 & 97,02 & Total & 100,34 & 100,40 & 99,01 & 99,56 & 101,03 & 97,02 \\
\hline
\end{tabular}

Table 7: Bulk melt pocket compositions based on mass balance calculation from modal and chemical compositions of phases. Comparison with pargasite amphibole compositions

(SZT111 and FT08P). 
Click here to download Table: Table 8.doc

\begin{tabular}{|c|c|c|c|c|c|c|}
\hline & Rock type & $\mathbf{T}$ primary $\left({ }^{\circ} \mathbf{C}\right)$ & Estimated P (GPa) & T cpxII-glass $\left({ }^{\circ} \mathbf{C}\right)$ & $\Delta \mathrm{T}\left({ }^{\circ} \mathrm{C}\right)$ & P cpxII-glass (GPa) \\
\hline SZB16 & Lhz & 1135 & 1.50 & & & \\
\hline SZB44 & Lhz & 992 & 1.28 & 1250 & 258 & 0.8 \\
\hline SZB50 & Lhz & 1007 & 1.14 & 1245 & 238 & 0.7 \\
\hline SZB51 & Lhz & 1039 & 1.27 & 1211 & 172 & 0.7 \\
\hline SZB52 & $\operatorname{Lhz}$ & 1128 & 1.59 & & & \\
\hline SZB66 & Lhz & 1029 & 1.36 & & & \\
\hline SZG14 & Lhz & 1086 & 1.30 & & & \\
\hline SZG23 & Lhz & 1041 & 1.30 & 1228 & 187 & 0.7 \\
\hline SZG30 & Lhz & 1052 & 1.25 & & & \\
\hline SZG44 & $\operatorname{Lhz}$ & 1086 & 1.17 & 1267 & 181 & 0.9 \\
\hline FT12 & Lhz & 968 & 1.15 & 1207 & 239 & 0.6 \\
\hline FT01P & $\mathrm{Hbz}$ & 1137 & 1.63 & & & \\
\hline FT08P & $\mathrm{Hbz}$ & 852 & 1.07 & 1222 & 370 & 0.6 \\
\hline MSZK1306A & $\operatorname{Lhz}$ & 861 & 1.07 & & & \\
\hline MSZK1308 & Lhz & 1080 & 1.39 & & & \\
\hline
\end{tabular}

Table 8: Minimum $\mathrm{T}$ and $\mathrm{P}$ of melt pocket formation in the lithospheric mantle beneath the BBHVF. T for the primary mantle mineral assemblage calculated after Brey \& Kohler (1990); Estimated P from T equilibrium and Kovacs et al. (2012) geotherm; dT = temperature difference between the mantle minerals and melt pocket phases 